\title{
Extending Medicare to Mexico: Impact on Mexican-Born Beneficiaries
}

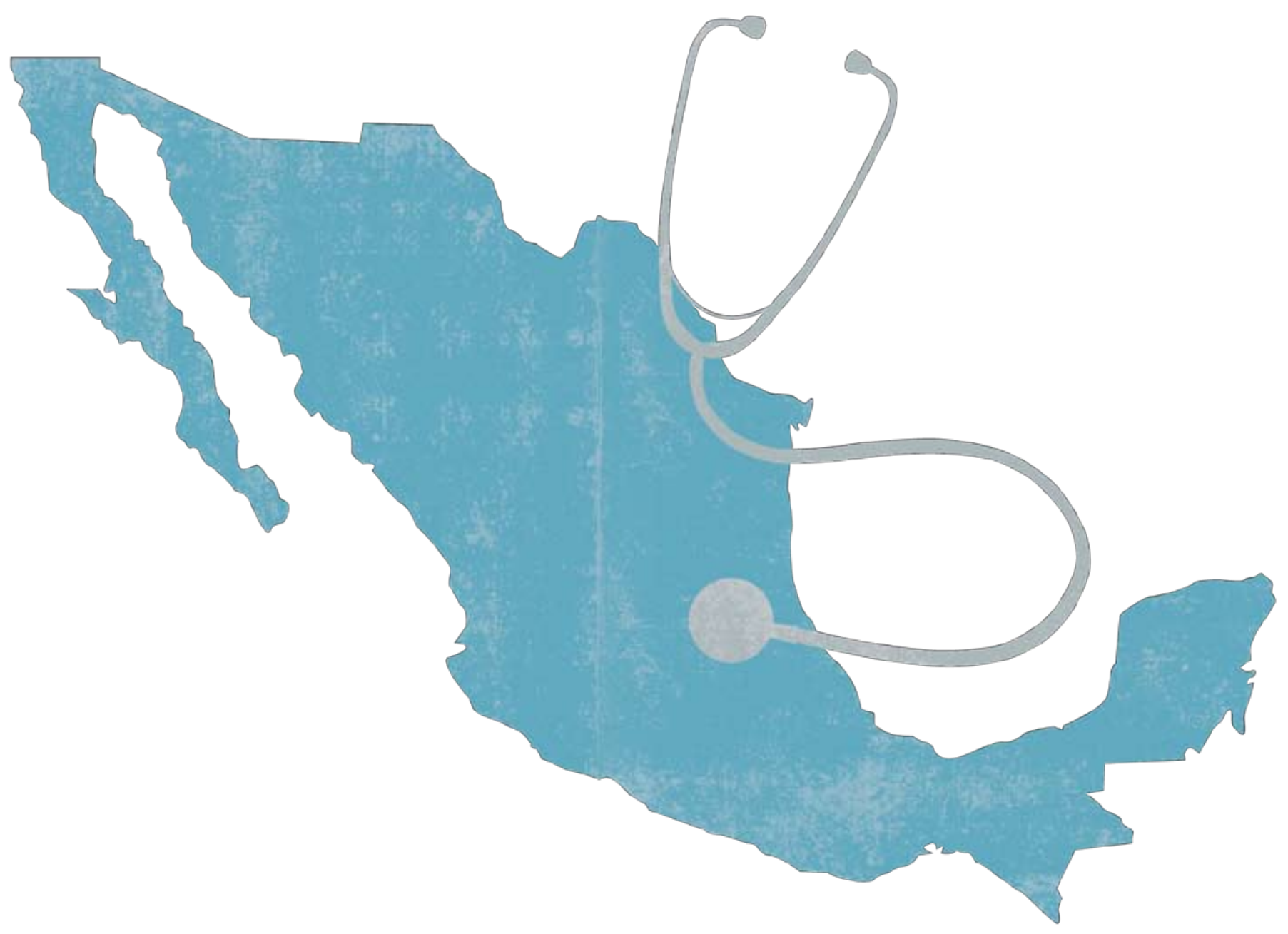

Lyndon B. Johnson School of Public Affairs The University of Texas at Austin Policy Research Project Report 
Lyndon B. Johnson School of Public Affairs

Policy Research Project Report

Number 168

\section{Extending Medicare to Mexico: Impact on Mexican-Born Beneficiaries}

Project Directed by

David C. Warner

\footnotetext{
A report by the

Policy Research project on

Medicare in Mexico for Mexican-Born Beneficiaries

2010
} 
The LBJ School of Public Affairs publishes a wide range of public policy issue titles. For order information and book availability call 512-471-4218 or write to: Office of Communications, Lyndon B. Johnson School of Public Affairs, The University of Texas at Austin, Box Y, Austin, TX 78713-8925. Information is also available online at www.utexas.edu/lbj/pubs/.

Library of Congress Control No.: 2010930094 ISBN: 978-0-89940-786-9

(C2010 by The University of Texas at Austin All rights reserved. No part of this publication or any corresponding electronic text and/or images may be reproduced or transmitted in any form or by any means, electronic or mechanical, including photocopying, recording, or any information storage and retrieval system, without permission in writing from the publisher.

Printed in the U.S.A.

Cover design by Doug Marshall (LBJ School) and Tony Beardmore (graphic designer) 


\section{Policy Research Project Participants}

\section{Students}

Meghan Ashford-Grooms, B.A. (Classics and History), Columbia University

Elizabeth Chmelik, M.D. and B.A. (History), The University of Florida

Andrea Haughton, B.A. (Political Science) and B.A (Journalism), Texas State University

Robin Lynch, B.S. (Civil Engineering), The University of Texas at Austin

Timothy Mattison, B.S. (Political Science), The University of Wisconsin at La Crosse;

M.A. (Russian, Eastern European and Eurasian Studies), The University of Texas at

Austin

Alani Mayela Mundie, B.A. (Government), The University of Texas at Austin

Jennifer Schmalz, B.A. (International Studies), The University of St. Thomas

Shelby Tracy, B.J. (Journalism), The University of Texas at Austin

Lisa Morgan Wallace, B.S. (Physical Oceanography and Meteorology, General

Engineering, Spanish), United States Naval Academy

\section{Project Director}

David C. Warner, M.P.A., Ph.D., Professor of Public Affairs and Wilbur Cohen

Professor, LBJ School of Public Affairs, The University of Texas at Austin 
(this page intentionally left blank) 


\section{Table of Contents}

List of Tables...................................................................................................

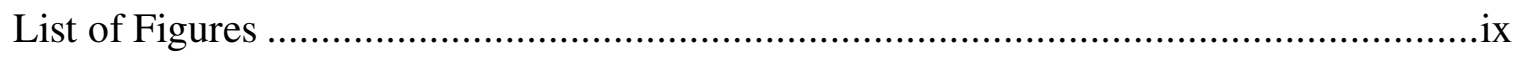

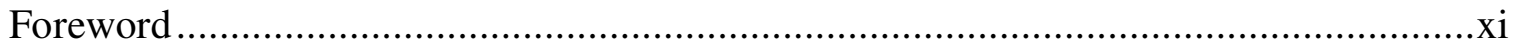

Acknowledgments ...................................................................................... xiii

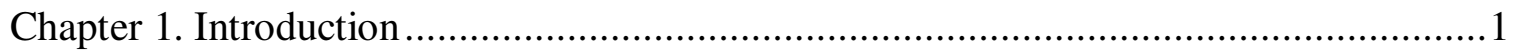

Chapter 2. Immigration and Public Benefits....................................................

Chapter 3. Mexican Migration to the United States ............................................... 15

Chapter 4. Mexican-American Immigration to the Dallas Fort-Worth Metroplex ...........37

Chapter 5. Mexican-American Immigration to Los Angeles.....................................43

Chapter 6. Healthcare Portability in Europe: European Union Policy and Individual Member State Bilateral Agreements............................................................... 47

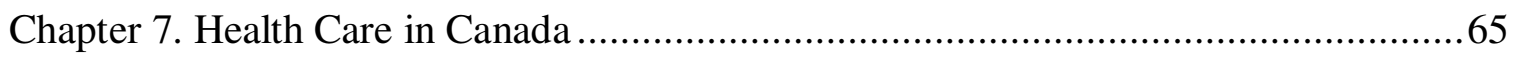

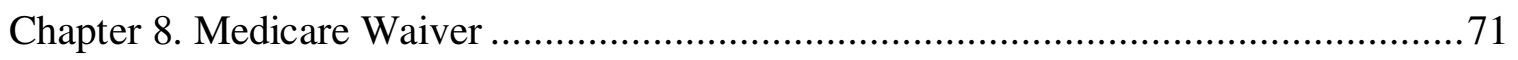

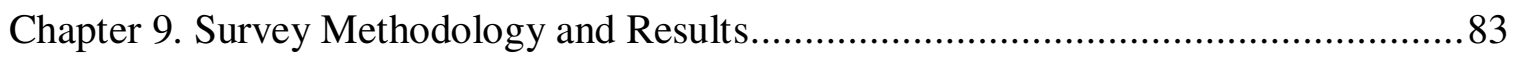

Chapter 10. Personal Interviews: The Impact of Medicare Portability on Individuals ... 103

Appendix A. Example of Congressional Proposals ............................................ 111

Appendix B. Medicare in Mexico Survey ….................................................. 119

Appendix C. Encuesta: Medicare en México..................................................... 123 
(this page intentionally left blank) 


\section{List of Tables}

Table 7.1 Canadian Provincial Health Care............................................................67

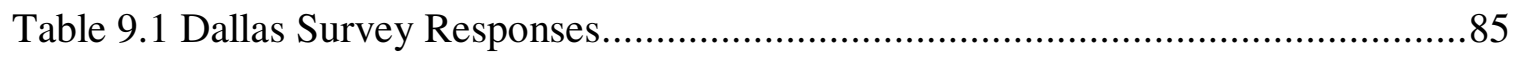

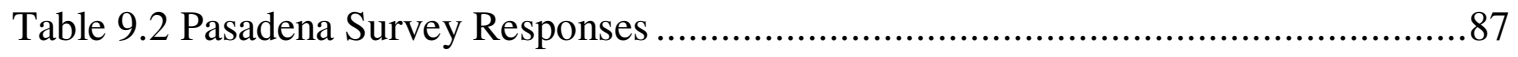

Table 9.3 Austin Survey Responses ........................................................... 90

Table 9.4 Guanajuato, Mexico, Survey Responses .............................................93

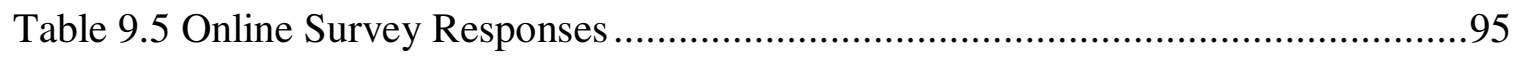

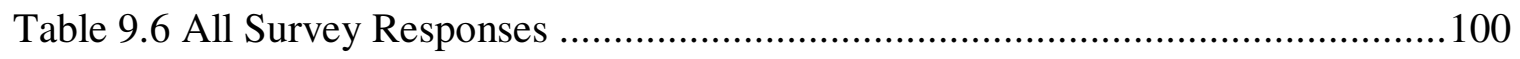


(this page intentionally left blank) 


\section{List of Figures}

Figure 4.1 Percentage of Mexican-Born Population per Census Tract in Dallas County, 2000

Figure 4.2 Percentage of Mexican-Born Population per Census Tract in Tarrant County, 2000

Figure 4.3 Native and Foreign Population in North Texas with Top Ten Immigrant Populations, 2000

Figure 5.1 Congressional Districts in Metropolitan Los Angeles Showing Number of Mexican-Born Population per Census Tract, 2000........................................45

Figure 9.1 Retirement Location Preference (Brady Center, Dallas, Texas) ...................84

Figure 9.2 Reasons for Retirement Preference (Brady Center, Dallas, Texas) ...............85

Figure 9.3 Planned Retirement Location (Pasadena, Texas) ......................................87

Figure 9.4 Planned Retirement Location (Austin, Texas) ......................................89

Figure 9.5 Reasons for Retirement Preference (Austin, Texas) ................................90

Figure 9.6 Health Care Location (Guanajuato, Mexico) .........................................92

Figure 9.7 People Receiving U.S. Public Benefits (Guanajuato, Mexico).....................92

Figure 9.8 Preferred Retirement Location (Online Survey) ....................................95

Figure 9.9 Reasons for Retirement Preference (Online Survey) ...............................95

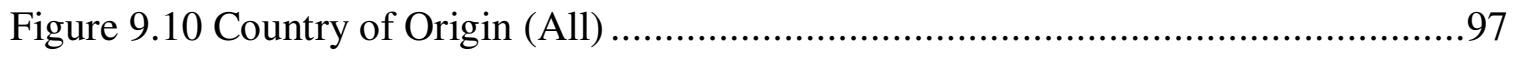

Figure 9.11 Family Location in Mexico (All) .........................................................98

Figure 9.12 Preferred Retirement Location ..................................................98

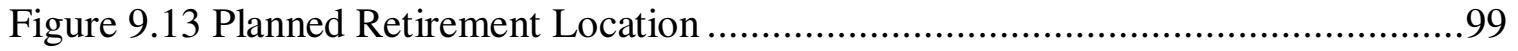

Figure 9.14 Reasons for Retirement Preference (All) .......................................99 
(this page intentionally left blank) 


\section{Foreword}

The Lyndon B. Johnson School of Public Affairs has established interdisciplinary research on policy problems as the core of its educational program. A major part of this program is the nine-month policy research project, in the course of which faculty members direct the research of a small group of graduate students of diverse backgrounds on a policy issue of concern to a government or nonprofit agency. This "client orientation" brings the students face to face with administrators, legislators, and other officials active in the policy process and demonstrates that research in a policy environment demands special talents. It also illuminates the occasional difficulties of relating research findings to the world of political realities.

This publication presents the results of a policy research project conducted during the 2009-2010 academic year that examined the availability of health coverage in Mexico for Mexican-born persons who are or soon will be Medicare beneficiaries. This project included developing a questionnaire in English and Spanish and administering it to a number of individuals in Dallas, Austin, and the state of Guanajuato, Mexico. In addition a version of the survey is on the web at http://www.medicareinmexico.us. This report also presents information on patterns of immigration to the U.S. from Mexico, changes in naturalization law, and a close look at a number of Congressional districts in greater Los Angeles and the Dallas-Fort Worth metroplex. The portability of Medicare benefits from the U.S. to Mexico is compared to the portability of benefits within the European Union. The report also examines coverage by both the Canadian and European health systems of emergencies abroad. The report concludes with a discussion of a possible Medicare waiver which would permit Medicare to pay for emergency medical services when beneficiaries were either visiting or retired there.

This policy research project has benefitted from support from the Policy Research Institute (International) at the Lyndon B. Johnson School of Public Affairs, the Wilbur J. Cohen Professorship in Health and Social Policy, and from the CBIRD initiative, which was funded by the RGK Foundation through the $\mathrm{IC}^{2}$ at the University of Texas at Austin.

The curriculum of the LBJ School is intended not only to develop effective public servants but also to produce research that will enlighten and inform those already engaged in the policy process. The project that resulted in this report has helped to accomplish the first task; it is our hope that the report itself will contribute to the second.

Finally, it should be noted that neither the LBJ School nor The University of Texas at Austin necessarily endorses the views or findings of this report.

Robert Hutchings

Dean 


\section{Acknowledgments}

This Policy Research Project has benefitted from help provided by many. During the course of the project, speakers to the class included George Rivas, a U.S. foreign service officer stationed in Hermosillo, Mexico, who explained how citizenship and immigration issues are handled at consulates abroad; Professor Namkee Choi of the University of Texas School of Social Work, who shared her expertise in interviewing Hispanic elderly; Cesar Martinez, a doctoral student at the LBJ School; Lauren Jahnke, who discussed editing issues; Annie Crawford, director of the Ventanilla de Salud at the Mexican consulate in Austin; Stephen Littrell, director of the LBJ School Library and Head Librarian for Access Services, who helped us understand some of the resources available to researchers; Anne Messbarger-Equia of Christus Health, who provided a valuable overview of Christus Health International Ministries in Mexico; and Thomas Methvin, who described some of the results from his research on the retirees near Lake Chapala.

In Dallas-Fort Worth, we were helped by Dr. Jaime Gonzales of United Healthcare; Guadalupe Vazquez of the Oficina de Enlace en Texas del Gobierno del Estado de Guanajuato de Asuntos Migratorios de la DGAM; Maria Montes of The Brady Center; and Sylvia Lagos of La Voz del Anciano. In Pasadena, Texas, Julio Ruiz of a Guanajuato hometown association distributed surveys to his members.

In Guanajuato, we were helped by Silvia Ramirez, a California representative for Casa Guanajuato; Fabio Caudillo, the Silao Representative for Atención al Migrante; and Graciela Segura Vasquez, a delegada (town leader) of El Maguey.

In Los Angeles, we were helped by Arturo Carmona, Executive Director of Consejo de Federaciones Mexicanas en Norteamerica (COFEM), who provided us with a number of contacts; Professor David Hayes Bautista of UCLA, who served as a valuable sounding board and made several referrals; Marie Torres, research director at Alta Med, who provided insight into improving our survey; Professor Leo Estrada of UCLA, who provided information about AARP; and Therese Hughes of Congresswoman Linda Sanchez's office and Yoomee Ha of Congressman Xavier Becerra's office, who both provided very helpful comments about the process and the research that would be needed.

Other experts and who have been supportive and helpful include Bryan Roberts, director of the Mexican Center at the Lozano Long Institute for Latin American Studies at UT Austin; Russell Bennett, director of Latino Health Solutions for United Healthcare; Karl Eschbach, the Texas state demographer; and Randy Capps of the Migration Policy Institute.

In the course of the research, Kate Chambers provided technical assistance with regard to analyzing 2008 American Community Survey data from the U.S. Census Bureau, as well as helping with the development of the project's website at www.medicareinmexico.us. Also, Seve Kale was an undergraduate intern who helped administer the survey in Austin 
and research migration trends. Akshara Richhariya was a member of the PRP in the fall semester and participated in the development of the survey and the chapter on Europe.

This Policy Research Project has benefitted from support from the Policy Research Institute (International) at the LBJ School of Public Affairs, from the Wilbur J. Cohen Professorship in Health and Social Policy, and from the CBIRD initiative which was funded by the RGK Foundation through the $\mathrm{IC}^{2}$ at the University of Texas.

As has been the case many times before, Lauren Jahnke has performed valiantly in pushing all of us into a consistency that is required to publish. 


\section{Chapter 1. Introduction}

\section{by Alani Mundie and Lisa Morgan Wallace}

This Policy Research Project (PRP) is the latest in a number of projects that have been conducted at the LBJ School of Public Affairs at The University of Texas at Austin that examine barriers to health systems becoming more integrated between the U.S. and Mexico. ${ }^{1}$

This project takes another step in attempting to examine the consequences of the lack of portability of benefits between the U.S. and Mexico. In particular we are looking at the Mexican-born population that has or will soon have an entitlement to Social Security and Medicare. It is a population that appears to be somewhat concentrated in the Los Angeles and the Dallas-Fort Worth metropolitan areas. This project should be seen as primarily exploratory as it proved very difficult for us to reach a large number of people who met our criteria, even though the U.S. Census Bureau estimates that 470,000 Mexican-born persons residing in the United States over the age of 65 were receiving Medicare in $2008 .^{2}$

Movement of people across the border with Mexico has resulted in a net flow of millions of individuals into the United States. About 11.5 million individuals identify themselves as Mexican-born. ${ }^{3}$ In addition, the Pew Center estimates 31 million people identified themselves of Mexican origin in 2008. ${ }^{4}$ Many individuals in this population still have family remaining in Mexico and travel back to Mexico frequently throughout their lifetimes. Others return to Mexico in old age to retire near family or to enjoy a lower cost of living after their working years have come to an end.

For many, access to health care is increasingly important later in life. Because Medicare covers health care outside of the United States only in rare cases, many beneficiaries who retire to Mexico must travel to the United States for needed preventive and acute care services. In some instances, these retirees choose to forgo needed care or to pay out-ofpocket for services in Mexico. Without access to their Medicare benefits, these retirees are more vulnerable to the potentially devastating financial consequences of inadequate health insurance coverage. As the demography in the United States changes and more Mexican-origin Americans retire to their native country, government-sponsored health care coverage for U.S. retirees should examine options to adapt to the needs of its diverse beneficiaries.

This research investigates whether or not providing Medicare coverage in Mexico would influence the retirement decisions of Mexican-origin individuals who are eligible Medicare beneficiaries. A survey was conducted both online and in person to test the hypothesis that an increased availability of U.S. public health care benefits for the elderly in Mexico would result in a greater return migration to Mexico for retirement. Based on our limited sample, results indicate that although people retired to Mexico do indeed travel back to the United States to receive Medicare-covered health care, most do not 
seem to be heavily influenced in their retirement decisions by the local availability of Medicare. Those who live in the United States but make extended visits to Mexico would benefit more from emergency service coverage than from the availability of benefits for regular health care consumption.

In addition to this survey, a few personal interviews were conducted with Mexican-origin individuals, in both the United States and Mexico, to receive first-hand, detailed accounts of how the lack of Medicare coverage in Mexico has affected their lives. Although the availability of Medicare benefits did not heavily influence the location of retirement (in either the United States or Mexico) for the individuals interviewed, the impact that the lack of coverage had on those retired in Mexico was significant. The interest in Medicare portability for those retired in Mexico was unanimous.

Because of lower health care costs in Mexico, it is likely that extending Medicare coverage south of the border would reduce U.S. government expenses and improve the well-being of American retirees in Mexico. We have identified congressional districts with large Mexican-born populations to begin to understand where a change in this Medicare policy would have the largest impact.

For Medicare benefits to be offered in Mexico, a series of steps must be taken. The Center for Medicare and Medicaid Services, a federal agency within the U.S. Department of Health and Human Services, is authorized to conduct and sponsor demonstration projects to test and measure the effect of potential program changes. However, Congressional approval could be needed for any pilot project to be conducted in Mexico.

Three different Medicare waiver options are identified below for extending care to Mexico at various levels of coverage: emergency care only, all care in Mexico only, or all care no matter the country. The research team explored the targeted populations and expected cost savings with each option. Based upon survey results, it is recommend that a waiver demonstration program be undertaken to cover only emergency health care services for Medicare beneficiaries when they are in Mexico at this time. 


\section{Notes}

${ }^{1}$ For previous projects see: The Health of Mexican Americans in South Texas, Policy Research Project Report no. 32, Lyndon B. Johnson School of Public Affairs, The University of Texas at Austin, 1979; Linda Chan, Roy McCandless, Bernard Portnoy, Chandler Stolp and David Warner, Maternal and Child Health on the U.S.-Mexican Border, Special Project Report, Lyndon B. Johnson School of Public Affairs, The University of Texas at Austin, 1987; David Warner and Kevin Reed, Project Directors, Health Care Across the Border: The Experience of U.S. Citizens in Mexico, U.S.-Mexican Policy Studies Program, Policy Report no. 4, Lyndon B. Johnson School of Public Affairs, The University of Texas at Austin, 1993; David Warner, Project Director, NAFTA and Trade in Medical Services between the U.S. and Mexico, U.S. Mexican Policy Studies Program, Policy Report no. 7, Lyndon B. Johnson School of Public Affairs, The University of Texas at Austin, 1997; David Warner, Project Director, Getting What You Paid For: Extending Medicare to Eligible Beneficiaries in Mexico, U.S.-Mexican Policy Studies Program, Policy Report no. 10, Lyndon B. Johnson School of Public Affairs, The University of Texas at Austin, 1999; Health Workforce Needs: Opportunities for U.S. Mexico Collaboration, 2003 Proceedings and Background Papers, Center for Health and Social Policy, Lyndon B. Johnson School of Public Affairs, The University of Texas at Austin and Regional Center for Health Workforce Studies, Center for Health Economics and Policy, The University of Texas Health Science Center at San Antonio, December 2003; David C. Warner and Pablo Schneider, Project Directors, Cross Border Health Insurance: Options for Texas, U.S. Mexican Policy Studies Program, Policy Report No. 12, Lyndon B. Johnson School of Public Affairs, The University of Texas at Austin, 2004 ; David C. Warner, Project Director, Medicare in Mexico: Innovating for Fairness and Cost Savings, Policy Research Project Report no. 156, Lyndon B. Johnson School of Public Affairs, The University of Texas at Austin, 2007.

${ }^{2}$ U.S. Census Bureau, 2008 American Community Survey. Online. Available: http://factfinder.census.gov. Accessed: May 28, 2010.

${ }^{3}$ U.S. Census Bureau, 2006-2008 American Community Survey, Table B05006, "Place of Birth for the Foreign Born Population.” Online. Available: http://factfinder.census.gov. Accessed: May 28, 2010.

${ }^{4}$ Pew Hispanic Center, Hispanics of Mexican Origin in the United States, 2008 (Washington, D.C., April 22, 2010), p. 1. 
(this page intentionally left blank) 


\title{
Chapter 2. Immigration and Public Benefits
}

\author{
by Lisa Morgan Wallace, Meghan Ashford-Grooms, and Elizabeth Chmelik
}

\section{U.S. Permanent Residency and Citizenship}

Immigration to the United States is by no means a simple process. In order to live permanently in America as a foreign-born individual with legal status, one must become either a legal permanent resident (LPR) or a United States citizen. Permanent residency involves carrying a green card, which authorizes its holder to live and work in the United States. ${ }^{1}$ Citizenship, in addition, extends the right to vote and guaranteed access to government services and entitlements. ${ }^{2}$

\section{Permanent Residence}

Immigrants can become legal permanent residents in a number of ways, the most common of which is through sponsorship by a qualifying U.S. citizen family member. ${ }^{3}$ Other ways include obtaining a green card through employment, a job offer, and refugee or asylum status. ${ }^{4}$ The basic eligibility criteria require that an applicant:

- is eligible for a recognized immigration category,

- has a qualifying immigrant petition filed and approved,

- has an immigrant visa, and

- $\quad$ is admissible to the United States. ${ }^{5}$

To maintain immigration status, legal permanent residents must not be convicted of a felony ${ }^{6}$ and also must maintain their permanent residence in the United States. Lengthy absences outside the country could result in the revocation of their status if they are deemed to have abandoned their residency. ${ }^{7}$ The U.S. Citizenship and Immigration Service (CIS) reserves the right to classify people as having abandoned their status based on absences of longer than one year if their stated reason for the absence supports an intentional abandonment of residency. In sum, the CIS may consider an LPR as having abandoned their permanent resident status if:

- he or she leaves the country for more than a year without obtaining a re-entry permit or a returning resident visa and does not intend to return;

- he or she remains outside of the United States for more than two years after issuance of a re-entry permit without obtaining a returning resident visa;

- he or she accepts employment outside of the country and does not keep ties to the United States;

- he or she fails to file U.S. income tax returns while living outside the country. ${ }^{8}$ 
Essentially, a person can re-enter the country as a legal permanent resident as long as he or she has not been gone longer than one year. Otherwise, a permit or visa is needed. ${ }^{9}$

The requirement for continuous residency is bound by complicated parameters. If an LPR leaves the country for more than six months but less than one year, he or she has disrupted his or her continuous residence, which is reset to zero years. However, documents that show that the LPR's family continued to live, work, or keep ties to the United States can be used to prove undisrupted continuous residence.

Spending more than one year outside the United States is a disruption of continuous residence even when the LPR has a re-entry permit. None of the time spent in the States before leaving the country will count toward continuous residence. If the person returns within two years, however, some of the final 364 days spent abroad will be used toward meeting the continuous residence requirement. ${ }^{10}$

\section{Citizenship}

Permanent residents who wish to become U.S. citizens must go through a process known as naturalization, which requires applicants to meet requirements such as

- time spent as a permanent resident,

- continuous residence in the United States,

- a physical presence in the States, and

- English and American civics knowledge. ${ }^{11}$

The most common applicant category "no special circumstances" has more specific requirements. The person must be

- more than 18 years old,

- a legal permanent resident for five years without leaving the country for trips of six continuous months or longer,

- residing in the United States for a total of 30 nonconsecutive months out of the five years of residency immediately prior to applying for citizenship, and

- able to pass the English and civics tests. ${ }^{12}$

Spouses of U.S. citizens who wish to naturalize have slightly different requirements. They must

- be at least 18 years old,

- have married an individual who has been a citizen for three years,

- stay married to and live with the citizen for three continuous years,

- be an LPR for three years without leaving the U.S. for trips of six months or longer,

- have been in the United States for a total of 18 months, and

- pass the English and civics test. ${ }^{13}$ 
There are some age-based exceptions to the English test requirements for naturalization. To qualify for these exceptions, the time that an applicant spent as a permanent resident does not have to be continuous, but time spent living in the United States not as an LPR does not count toward the exemption. ${ }^{14}$ These exceptions are as follows:

- If a person is older than 50 and has lived in the States as an LPR for periods that total at least 20 years, no English test is required, and the civics test can be taken in the language of the applicant's choice.

- If a person is older than 55 and has lived in the States as an LPR for periods that total at least 15 years, no English test is required, and the civics test can be taken in the language of the applicant's choice.

- If a person is older than 65 and has lived in the States as an LPR for periods that total at least 20 years, no English test is required, and the civics test can be taken in the language of the applicant's choice.

Once citizenship is obtained, a U.S. citizen may petition for an immigrant visa for their spouse even when the spouse lives abroad. ${ }^{16}$ Once the request is approved the spouse can apply for lawful permanent residence at the embassy or consulate. Just as when the spouse resides in the United States, they must be a permanent resident for three years to be able to apply for citizenship. ${ }^{17}$

Similarly, a citizen can file an immigrant petition on behalf of his or her parents to adjust their status to permanent residency. ${ }^{18}$ This is accomplished using a process similar to that for spouses by signing an affidavit of support, which is an enforceable agreement promising that the citizen will be responsible for supporting the immigrating relative at a level equivalent to 125 percent of federal poverty guidelines. If a petitioner does not have the resources to provide such financial support, a joint petitioner may co-sign to undertake this responsibility, which continues until the parent or other family member can be credited with 40 quarters (10 years) of sufficient income, to which their spouse can contribute for a shorter wait time of as little as five years. ${ }^{19}$ Once the petition is approved, the parents may in turn begin applying for LPR status.

\section{U.S. Public Benefits}

As legal residents of the United States, employed legal permanent residents and citizens contribute to the Social Security and Medicare funds through payroll tax assessments. ${ }^{20}$ They can receive the benefits of both programs if they or their spouse meets work-based qualifications.

\section{Social Security}

As a new citizen or legal permanent resident, a person is eligible to work in the United States and to contribute to work-based benefits such as Social Security. As a national social insurance and pension program, Social Security provides payments to individuals over the age of 65 who have paid at least the minimum amount annually into the Social Security trust fund for an adequate number of years. ${ }^{21}$ People who work and pay taxes earn up to four Social Security credits per year. A minimum of 40 credits (equivalent to 
10 years of work) is required to qualify for benefit payments, though fewer credits are needed for disability benefits and for relatives eligible for survivor benefits. ${ }^{22}$ Social Security beneficiaries can choose to retire and receive benefits as early as age 62 or to defer these benefits up to their $70^{\text {th }}$ birthday.

\section{Social Security Benefits Outside of the United States}

U.S. citizens who move to Mexico can receive their Social Security payments abroad. In the same way, Mexican citizens who lived in the United States and qualified for Social Security benefits can receive payments in Mexico.

If a direct beneficiary dies, the situation becomes more complicated for relatives who want to move to or are already living in another country. In most cases, a spouse or child who is not a U.S. citizen receives Social Security payments in Mexico if

- they have already been receiving payments in the States,

- they lived in the States for at least five years, and

- the family relationship on which the benefits are based existed during those five years. $^{23}$

The situation is different if the surviving spouse and children live in Mexico. Children who are born abroad to at least one U.S. citizen are also U.S. citizens. In the case of a U.S. citizen's death in Mexico, a child can receive benefits until they are 18 years old or until they are 19 years and 2 months old if they are a full-time student. To be eligible, the child must prove the relationship to the primary beneficiary, be unmarried, and have been dependent upon the parent.

The process is fundamentally the same for children of beneficiaries who were not U.S. citizens. In this case, however, the parent must have amassed at least 40 Social Security credits for the children to receive payments. Dependent children of U.S. citizens, on the other hand, receive payments even if the worker had amassed fewer than 40 credits. $^{24}$

In the event of a death, a noncitizen widow(er) must go in person to a U.S. Embassy and file an application to receive benefits, regardless of whether the deceased was a citizen. To be eligible, the widow(er) must have been married to the deceased for at least one year and be older than 62 years of age. ${ }^{25}$ The widow(er) can be younger and receive benefits only if he or she is caring for a child who is younger than 16 .

\section{U.S. Social Security Totalization with Mexico}

The United States has signed social security totalization agreements with 21 foreign nations to coordinate its domestic social pension program with those of countries in which American citizens are working abroad. ${ }^{26}$ These numerous bilateral agreements exist to keep individual workers from paying social security taxes in two nations simultaneously, while providing those same workers with benefits that they might otherwise lose if they move abroad to work in another nation. ${ }^{27}$ Under the 2005 administration of George W. Bush, one such agreement was proposed to totalize Social Security programs for workers moving between the United States and Mexico. ${ }^{28}$ This 
agreement would have allowed those having contributed less than 40 quarters (10 years) of work in the United States and any amount of time in Mexico such that he or she earned a total of 40 credits to collect a pro-rated amount of Social Security as well as funds from an AFORE (Administradoras de Fondos para el Retiro) account or Mexican government pension program calculated based upon time worked in Mexico. Though this agreement was of very high priority to Mexican President Vicente Fox, it never reached final approval. It was estimated that the agreement would have impacted over 667,000 Mexican-born workers in 2008 and cost the United States almost \$129 million in Social Security payments to Mexican-born retirees. It would, however, also save American workers \$140 million in Social Security and health insurance tax payments to the Mexican government in its first five years of existence. ${ }^{29}$ The net cost to the United States after adjustment for cost savings would be an estimated \$105 million per year, which is less than the cost of America's equivalent \$197 million per year agreement with Canada. This initial net cost would be steady for the first five years, but the Social Security Administration Office of the Chief Actuary (OCACT) forecasts significant increases in cost over time with a projected price tag of 650 million inflation-adjusted dollars in 2050. ${ }^{30}$ This totalization agreement was stalled in Congress during the Bush administration and never went into effect. There are no indications at this time that the Obama administration has interest in renewing negotiations with Mexico over a new bilateral agreement for Social Security totalization between the two nations.

\section{Medicare}

Medicare is another United States social insurance program that provides health coverage to eligible recipients over the age of 65 , as well as certain other disabled persons. ${ }^{31}$ There are instances where people younger than age 65 qualify. One such categorical group is comprised of people with end-stage kidney disease who require dialysis or have had a transplant $^{32}$ and those with Amyotrophic Lateral Sclerosis (ALS), which is also known as Lou Gehrig's disease. ${ }^{33}$ These patients will often be eligible for Medicare coverage.

Another group exempted from the age requirement includes people with certain disabilities at any age. Generally, if someone qualifies for disability payments under the Supplemental Security Disability Insurance program (SSDI), then he or she may apply for Medicare benefits after receiving payments under SSDI for two years within the past five years. ${ }^{34}$ Some examples of disabilities that would qualify include heart failure, asthma, chronic back pain, and severe depression.

Finally, dependents of those who have paid into Medicare can be eligible for benefits if they meet very specific conditions. Children or widow(er)s age 50 or older with a qualifying disability can receive Medicare coverage for their health services and longterm care, as well as the dependant parent of a qualifying deceased child who paid Medicare taxes.

\section{Medicare Plan Structure}

The Medicare health care program is divided into several parts that have different qualification requirements, payment obligations, and covered services. These program segments are as follows: 
Part A, also known as "hospital insurance," covers costs for inpatient hospital care, as well as skilled nursing facilities, hospice services, and some home health care. ${ }^{35}$

Part B, or "Medical insurance," covers physician services, outpatient hospital care, some medical supplies, diagnostic services, occupational therapy, physical therapy, speech therapy and home health care if "medically necessary.",36

Part C encompasses the Medicare Advantage plans, which are similar to a Health Maintenance Organization (HMO) or managed care products. ${ }^{37}$ These plans are optional for purchase. Contracted vendors receive premiums and payments from Medicare and then provide services for patients. Each Medicare Advantage plan may have different benefits and levels of coverage. Individuals who live outside of the United States for more than six months of the year are not eligible for the Medicare Advantage Plan.

Part D is a prescription drug plan. ${ }^{38}$ Again, this plan is arranged through intermediary insurance companies that have different premiums, levels of coverage and drug formularies, which list pharmaceuticals covered at different cost points.

Individuals are recommended by the Social Security Administration (SSA) to sign up for Medicare Part A three months before their $65^{\text {th }}$ birthday. ${ }^{39}$ Those people already receiving retirement benefits that live in the United States are enrolled in Part A. Part B coverage is optional, but the premiums increase by 10 percent each year if one signs up for Part B after a seven-month grace period. There is an exemption if the person is still covered under a group health plan through current employment. Part $\mathrm{C}$ is a voluntary program and has the same enrollment periods with no associated penalties. Part $\mathrm{D}$, on the other hand, is also voluntary, but a penalty is incurred for joining after an enrollment period unless the individual is covered by another "creditable" drug benefit plan that is at least as good as Medicare prescription drug coverage. ${ }^{40}$

Individuals and their spouses who meet the basic Medicare eligibility requirement of 10 working years in the United States qualify for Part A free of charge. ${ }^{41}$ If a person does not meet employment or family-based enrollment criteria, he or she can still enroll in Part A by paying a monthly premium. All participants must meet a deductible and pay coinsurance on services received.

All Part B enrollees pay premiums. ${ }^{42}$ The basic premium covers on average 25 percent of the cost of Medicaid Part B, while the balance is covered by general revenue. These premiums are means-based and calculated from a base monthly cost and determined by income. Those making less than $\$ 85,000$ per year (or $\$ 170,000$ per household for joint filing) will pay the standard premium of $\$ 110.50$ in 2010 , which has increased by 15 percent in the past year. Those earning more than the income threshold will pay between $\$ 154$ and \$354 per person depending upon their income bracket.

\section{Medicare Benefits Outside of the United States}

Currently, Medicare will not cover health care services received outside of the United States. The only instance in which Medicare will pick up the cost of emergency services is when an appropriate foreign medical provider is closer to the service recipient's location in the United States and its territories than the next closest facility in United States territory. An exception to this rule occurs if one is driving directly between the 
United States and Canada, in which emergency care may be provided and paid for by Medicare if it occurs on this direct journey. One will not lose Medicare Part A coverage by staying outside of the United States as a permanent resident for more than some given amount of time. ${ }^{43}$ Continuous coverage under Parts B and D depends upon an individual outside of the country continuing to pay monthly premiums. If an individual allows this coverage to lapse, they will lose benefits under these parts and must wait until the annual enrollment period to re-enroll at a higher cost. In addition, if someone who is a permanent resident remains outside of the United States for an extended period at the time, they may lose their right to re-enter the country. Although such persons may have Medicare coverage, if they are not be able to return to the United States, they will not be able to use this coverage outside the country. 


\section{Notes}

${ }^{1}$ United States Citizenship and Immigration Services, Green Card (Permanent Residence) (September 1, 2009). Online. Available: http://www.ucis.gov/. Accessed: March 7, 2010.

${ }^{2}$ United States Citizenship and Immigration Services, Citizenship (September 10, 2009). Online. Available: http://www.ucis.gov/. Accessed: March 7, 2010.

${ }^{3}$ United States Citizenship and Immigration Services, Family of U.S. Citizens (December 21, 2009). Online. Available: http://www.ucis.gov/. Accessed: March 7, 2010.

${ }^{4}$ United States Citizenship and Immigration Services, Green Card (Permanent Residence) (online).

${ }^{5}$ United States Citizenship and Immigration Services, Green Card Eligibility (September 3, 2009). Online. Available: http://www.ucis.gov/. Accessed: March 7, 2010.

${ }^{6}$ United States Citizenship and Immigration Services, Rights and Responsibilities of a Green Card Holder (Permanent Resident) (May 2, 2010). Online. Available: http://www.ucis.gov/. Accessed: March 7, 2010.

${ }^{7}$ United States Citizenship and Immigration Services, International Travel as a Permanent Resident. Online. Available: http://www.ucis.gov/. Accessed: March 7, 2010.

${ }^{8}$ United States Citizenship and Immigration Services, Maintaining Permanent Residence. Online. Available: http://www.ucis.gov/. Accessed: March 7, 2010.

${ }^{9}$ Ibid.

${ }^{10}$ United States Citizenship and Immigration Services, "Time as a Permanent Resident," Guide to Naturalization, Document M-476 (Washington, D.C., February 2010), pp. 22-24.

${ }^{11}$ United States Citizenship and Immigration Services, Citizenship through Naturalization (September 12, 2009). Online. Available: http://www.ucis.gov/. Accessed: March 7, 2010.

${ }^{12}$ United States Citizenship and Immigration Services, General Path to Citizenship (September 10, 2009). Online. Available: http://www.ucis.gov/. Accessed: March 7, 2010.

${ }^{13}$ United States Citizenship and Immigration Services, Naturalization for Spouses of U.S. Citizens (September 15, 2009). Online. Available: http://www.ucis.gov/. Accessed: March 7, 2010.

${ }^{14}$ United States Citizenship and Immigration Services, Exceptions \& Accommodations (September 2009). Online. Available: http://www.ucis.gov/. Accessed: March 7, 2010.

${ }^{15}$ United States Citizenship and Immigration Services, "Time as a Permanent Resident," Guide to Naturalization, Document M-476 (Washington, D.C., February 2010), pp. 22-24.

${ }^{16}$ United States Citizenship and Immigration Services, Green Card through Family (September 2, 2009). Online. Available: http://www.ucis.gov/. Accessed: March 7, 2010. 
${ }^{17}$ United States Citizenship and Immigration Services, Naturalization for Spouses of U.S. Citizens (online).

${ }^{18}$ United States Citizenship and Immigration Services, Green Card for an Immediate Relative of a U.S. Citizen (March 2010). Online. Available: http://www.ucis.gov/. Accessed: March 7, 2010.

${ }^{19}$ Interview with Linton Joaquin, Esq., General Council Attorney for the National Immigration Law Center (NILC), Los Angeles, Calif., November 2009.

${ }^{20}$ Social Security Administration, "Paying Social Security Taxes," A "Snapshot" SSA Publication No. 510006 (Washington, D.C., May 2009), p. 4.

${ }^{21}$ Social Security Administration, "Retirement," A "Snapshot," SSA Publication No. 5-10006 (Washington, D.C., May 2009), p. 6.

${ }^{22}$ Social Security Administration, "Earning Social Security Credits," A "Snapshot," SSA Publication No. 5-10006 (Washington, D.C., May 2009), pp. 4-5.

${ }^{23}$ Social Security Administration, Your Payments While You are Outside the United States, SSA Publication No. 05-10137 (Washington, D.C., June 2009), pp. 12-13.

${ }^{24}$ Social Security Administration, "If you are working... what you need to know about survivors benefits," Survivors Benefits, SSA Publication No. 05-10084 (Washington, D.C., August 2009), pp. 5-6.

${ }^{25}$ Social Security Administration, "When a relative dies...what you need to know about survivor benefits," Survivors Benefits, SSA Publication No. 05-10084 (Washington, D.C., August 2009), pp. 7-9.

${ }^{26}$ Sullivan, Laura, Bringing Neighbors Closer Together: An Analysis of the U.S.-Mexico Social Security Totalization Agreement, LBJ School Professional Report (Austin, Tex., 2006), pp. 2-4.

${ }^{27}$ Social Security Administration, "Totalization," United States/Mexico Totalization Agreement (Washington, D.C., June 2004), p. 1. Online. Available: http://www.ssa.gov/pressoffice/. Accessed: September 18, 2009.

${ }^{28}$ Sullivan, Laura, Bringing Neighbors Closer Together, p. 5.

${ }^{29}$ Social Security Administration, “Totalization,” United States/Mexico Totalization Agreement (online).

${ }^{30}$ United States Government Accountability Office, Proposed Totalization Agreement with Mexico Presents Unique Challenges (Washington, D.C., September 2003), p. 14.

${ }^{31}$ Social Security Administration, "What is Medicare?," Medicare, SSA Publication No. 05-10043 (Washington, D.C., September 2009), p. 4.

${ }^{32}$ Centers for Medicare and Medicaid Services, Medicare Coverage of Kidney Dialysis and Kidney Transplant Services, CMS Product No. 10128 (Washington, D.C., December 2009), p. 7. 
${ }^{33}$ Centers for Medicare and Medicaid Services, Understanding Medicare Enrollment Periods, CMS Product No. 11219 (Washington, D.C. September 2009), p. 1.

${ }^{34}$ Centers for Medicare and Medicaid Services, Medicare and You 2010 (Washington, D.C., January 2010), p. 17.

${ }^{35}$ Social Security Administration, "Title XVIII - Health Insurance for the Aged and Disabled," Compilation of the Social Security Laws, Volume I (Washington, D.C., January 2007), Sec. 1811.

${ }^{36}$ Ibid., Sec. 1831.

${ }^{37}$ Ibid., Sec. 1851.

${ }^{38}$ Ibid., Sec. 1860.

${ }^{39}$ Social Security Administration, "Signing up for Medicare," Medicare, SSA Publication No. 05-10043 (Washington, D.C., September 2009), pp. 10-13.

${ }^{40}$ Centers for Medicare and Medicaid Services, Medicare and You 2010 (Washington, D.C., January 2010), p. 62.

${ }^{41}$ Ibid., pp. 16-18.

${ }^{42}$ Ibid., pp. 21-23.

${ }^{43}$ Social Security Administration, Your Payments While You Are Outside the United States What you need to know about Medicare, SSA Publication No. 05-10137 (Washington, D.C., June 2009), pp. 6-10. 


\title{
Chapter 3. Mexican Migration to the United States
}

\author{
by Shelby Tracy and Meghan Ashford-Grooms
}

Like many neighbors, the United States and Mexico have a complex relationship, often heavily influenced by changes in politics, economics, and nationalism. In addition to nearly 2,000 miles of border, the two countries share people: for more than 100 years, Mexicans have traveled to the United States, primarily for employment opportunities. Some have settled permanently while others have become transnational migrants, essentially maintaining ties on both sides of the border.

As a result of U.S. immigration policies, many Mexicans have gained legal status in the United States, which has made them eligible for entitlement programs such as Social Security and Medicare. According to some estimates, more than 5 million Mexicans residing in the United States in 2008 were either naturalized citizens or legal permanent residents. However, older transnationals who are eligible for the two social programs can receive only their Social Security benefits while residing in or visiting Mexico. In most cases, U.S. policies prevent Medicare recipients from using their government health insurance abroad. It is possible that this situation prevents some elderly people from returning to Mexico to visit or retire, a situation that will become more common as the number of Mexican-born people living in the United States continues to grow.

This paper will explore the changes in Mexican migration to the United States and the U.S. policies that have affected the flow and legal status of migrants.

\section{Early Migration}

Since Mexico ceded huge swaths of territory to the United States in 1848, migration from south to north has brought increasing numbers of Mexicans to the U.S. In its early days, the flow of workers contributed substantially to the construction of the U.S. railroad system and the development of American agriculture.

In the 1830s and 1840s, railroad companies hired German and Irish immigrants who were living in New York, Philadelphia, and Boston to perform the dangerous and grueling task of laying tracks. But when the railroad jobs moved into areas that were more rural, those workers did not want to leave their families to continue the projects and realized that they could earn more money under better conditions if they moved to agricultural jobs. ${ }^{1}$

After the Civil War, when the nation was looking to the railroads to help rebuild the nation, the companies again faced a shortage of workers and began to hire Chinese immigrants. However, public protests and discrimination against these workers led to the passage of the Exclusion Acts of 1882, which essentially forced the companies to cease hiring Chinese immigrants and to deport them-in many cases to Mexico. Again, the railroad companies were left without enough labor, and when they turned to continue their work to the south, they began to hire Mexicans living in the border areas. However, 
the border regions were not heavily populated, and Mexicans from other parts of the country, encouraged by both the governments of the United States and of Mexico, began to move to the U.S. to help build the railroad. Some experts consider this the first contract labor program for Mexicans in the United States. ${ }^{2}$ By 1910, the Mexican-born population of the United States numbered about 200,000 and was largely concentrated in Arizona and New Mexico. ${ }^{3}$

The railroad connected the Mexican state of Sonora with Arizona and led to a flood of Mexican immigration, especially during the Mexican revolution. The conflict in Mexico over honest elections during the reign of Porfirio Díaz eventually led to the election of Francisco Madero. The Madero presidency lasted from 1911 to 1913, when he was assassinated by Victoriano Huerta, effectively causing the Mexican Revolution. Huerta's reign brought dissent from all over Mexico, and a civil war began over the issue of land reform and indigenous rights. The link between Arizona and Sonora proved pivotal during the revolution, as sympathetic Americans and Mexican residents in Arizona helped smuggle arms across the border and provide asylum for revolutionary fighters. ${ }^{4}$ The turmoil in Mexico lasted until at least 1920, with minor outbreaks of violence occurring in the years that followed.

From the 1910 census to the 1921 census, the Mexican population decreased by about 1 million people. Nearly one-third of the loss is attributed to immigration to the United States as Mexicans tried to escape the civil war as well as an outbreak of the Spanish influenza. ${ }^{5}$ The Mexican-born population in the United States increased to nearly 490,000 in 1920 and then to about 640,000 in $1930 .^{6}$

Another guest worker program for Mexicans in the United States occurred during World War I and afterward, primarily from 1917 to 1921, when exceptions were made to the Exclusion Act of 1917 that allowed U.S. employers in the railroad, mining, and construction sectors to hire Mexicans as long as the companies could show a need. Scholars note that this program is not as well-known as the later Bracero Program because there was no official government monitoring. During this period, railroad companies continued to see their workers attracted away by agriculture and construction jobs, which offered better conditions and higher wages. As Mexican workers moved further into the United States, they began working in other industries, including meatpacking, automobile production, and steel production. ${ }^{7}$

Meanwhile in Mexico, the 1917 constitution had included an attempt to secularize the state. The election of Plutarco Calles (an atheist) in 1924 and his implementation of increasingly anti-clerical laws and provisions began a counter-revolution of the Catholic Church against the state, called the Cristero War. The violence was concentrated in western-central Mexico-Jalisco, Guanajuato, Aguascalientes, and Zacatecas - the states responsible for approximately 60 percent of immigration to the United States at that time. $^{8}$

The violence led to poor agricultural conditions and a disruption in the economy of those states. Although the Mexican federal government was attempting to limit immigration to the United States, local governments encouraged it as a means to alleviate the crisis. The 
Arandas government in Jalisco in particular began to issue "salvoconductos" that allowed passage through government checkpoints to the United States. Leading Cristeros were occasionally offered amnesty and safe passage to the United States if they surrendered. ${ }^{9}$

Chicago and its surrounding areas experienced a surge of Mexican immigrants during the 1920s and 1930s. Cristero violence as well as recruitment policies of railroad companies were responsible for the influx, resulting in communities of displaced Catholics and railroad workers. More than 28,000 Mexicans were spread throughout neighborhoods in East Chicago (Illinois) and South Chicago (Indiana) as well as the greater metropolitan area. $^{10}$

The onset of the Great Depression slowed the growth in Mexican migration. Immigrants were some of the first people to lose their jobs, and American anger at workers from Mexico, fueled by a belief that they were displacing U.S. laborers, led to a government repatriation program. ${ }^{11}$

\section{The Bracero Program}

The next period in American economic history, the industrialization of the late 1930s and the 1940s, set the stage for the official Bracero Program, which began in 1942. The traditional explanation given for the creation of the program, which brought an estimated 5 million Mexican agricultural workers to the United States, is that American agricultural workers were leaving their jobs to work in the new industrial sectors and therefore leaving vacancies in the fields. When World War II started, even more workers were needed in factories to help the war effort. Efforts to recruit American workers to fill the agricultural vacancies were unsuccessful, so in 1941, the growers asked the U.S. Department of Agriculture to allow them to hire workers from Mexico. ${ }^{12}$ Additionally, Mexican workers probably took the agricultural positions of many Japanese Americans, who had been placed in internment camps by the U.S. government during World War II. ${ }^{13}$

However, a report from the Center for Immigration Studies says the context for the launching of the Mexican Farm Labor Program is different from the traditional explanation. It argues that no shortage in agricultural labor existed, that government officials did not believe that one was forthcoming, and that the program was put into place because big agricultural interests wanted cheaper labor. ${ }^{14}$

Regardless of the reasons behind the program's birth, laborers from Mexico were brought to the United States through a series of agreements between the two countries. Twentysix states received Braceros, although most went to California, Texas, and Arizona. ${ }^{15}$ Under the terms of the agreements, Braceros were to receive a guaranteed wage and humane treatment during their temporary stints in the U.S. ${ }^{16}$ But since the end of the program, in 1964, many abuses of the Mexican laborers have been recorded, and some scholars argue that as the U.S. moved into the civil rights era, the program began to be seen as an exploitative labor system, which helped lead to its demise. ${ }^{17}$ 
The number of workers brought into the U.S. during the Bracero Program fluctuated because of several factors. Although the laborers were required to return to Mexico when their visas expired, some did not, causing an increase in illegal immigration. That jump sparked a public backlash against the workers, who again were seen as taking jobs from Americans and were also blamed for increases in crime, disease, and illiteracy. In response to this, a series of mass deportations called Operation Wetback was launched in Texas in 1954. Some official histories put the number of people returned to Mexico through this initiative at 1.1 million. ${ }^{18}$

However, the crackdown angered many agricultural interests because the deportations created labor disruptions, and after the operation, the Bracero Program was dramatically expanded. Previously, a maximum of about 200,000 visas was given out each year, but from 1955 through 1959, more than 400,000 visas were issued annually. ${ }^{19}$

\section{The Modern Era}

The period after the end of the Bracero Program has been dubbed by scholars as the start of the modern era of Mexican migration to the United States.

Marcela Cerrutti and Douglas S. Massey analyzed migration trends from 1965 to 1995 using data from the Mexican Migration Project, a research effort started in 1982 because of the lack of information on the subject. The data for the project is gathered through ethnographic surveys of areas where migrants originate and where they move on both sides of the U.S.-Mexico border. The first surveys were done in communities in the "traditional heartland" for migration to the United States-central and western Mexico, particularly the states of Guanajuato, Jalisco, Michoacan, San Luis Potosi, and Zacatecas, as well as the less-populous states of Aguascalientes, Colima, and Nayarit. Since the start of data collection, at least half of all migrants to the U.S. have originated in one of those states. $^{20}$

One of the most significant changes in U.S. immigration policy occurred in 1965, when new amendments to the Immigration and Nationality Act were passed. The Hart-Celler Act, named after sponsors Sen. Philip Hart of Michigan and Rep. Emanuel Celler of New York, abolished the national origins quota system that had been in effect since the 1920s and established new limitations. The old system had essentially prohibited immigration from Africa and Asia, and strict limits on entries by people from southern and eastern Europe were in place. Under the new formula, each country in Europe, Africa, Asia and the Pacific_-dubbed the "Eastern Hemisphere"-could have up to 20,000 visas per year, with priority going to relatives of U.S. citizens and permanent residents and people who possessed skills that were considered in need in the U.S. For these regions, there was an annual limit of 170,000 visas per year. ${ }^{21}$

Throughout the world, immediate relatives of U.S. citizens - defined as spouses, children younger than 21, and parents-were exempt from the numerical restrictions, but for the Eastern Hemisphere nations, the law established capped preference categories for other kinds of relatives, including unmarried adult children of U.S. citizens, spouses and unmarried children of permanent residents, married children of U.S. citizens, and never- 
married brothers and sisters of U.S. citizens. The total family preference entries were limited to 216,000 annually. ${ }^{22}$

Meanwhile, neither the per-country quotas nor the family preference categories applied to the nations of North America, South America, and the Caribbean-the "Western Hemisphere"-although there was an annual ceiling of 120,000 entries per year for the entire region. ${ }^{23}$ It marked the first time that Western Hemisphere nations, including Mexico, had been subject to any numerical limits.

Based on the new formula, the U.S. immigration system now had an overall ceiling of 290,000 entries, with no limit on the entry of U.S. citizens' immediate family members.

During the period after the law's passage but before the new quota system was implemented, Cerrutti and Massey have found evidence of a first wave of legalization of Mexican immigrants as American employers moved to sponsor former Braceros and their family members. The first spike in legalization included mostly males, the sons and brothers of former Braceros who reached legal status through their family connections. A second, smaller spike occurred a few years later when Mexican wives and daughters came to join their relatives in the U.S. ${ }^{24}$

After 1968, further amendments to the Immigration and Nationality Act made it more difficult to emigrate from Mexico to the U.S. In 1976, the Western Hemisphere became subject to the 20,000-visas-per-nation rule, which immediately cut the inflow of Mexicans by 25 percent. And in 1978, the hemispheric caps on entries were scrapped and replaced with a worldwide limit of 290,000 visas, a number that dropped even lower in 1980 , to $270,000 .^{25}$

\section{The Immigration Reform and Control Act}

The volume of Mexican immigration to the United States grew dramatically after 1965. At the end of World War II, Mexican-born people living in the United States numbered only about 500,000. Between 1970 and 2006, that population increased fifteen-fold, to nearly 12 million, precipitated in part by the end of the Bracero Program and the changes to U.S. immigration policy. ${ }^{26}$

Several consequences of the Hart-Celler Act paved the way for the United States' next major immigration policy changes: the number of entries rose dramatically, the immigrant population became more Asian and Latino and less European, and the number of illegal immigrants from the Western Hemisphere grew because those nations were subject to quotas for the first time. ${ }^{27}$ Scholars generally agree that net migration from Mexico, including both legal and illegal immigrants, averaged about 250,000 people per year during the 1980s. ${ }^{28}$ Meanwhile, between 1964 and the mid-1980s, the United States experienced significant economic stress, including high rates of unemployment, stagnating wages, and rising inequality. All of these factors contributed to the creation of a movement to change U.S. immigration policy. The public began to push for stricter rules governing the flow of legal immigrants and to demand that action be taken to curtail illegal immigration. $^{29}$ 
Congress passed the Immigration Reform and Control Act in October 1986, and President Reagan signed it into law the following month. The legislation included several important provisions, but its main goal was to reduce illegal immigration by giving legal status to undocumented immigrants who were already in the country, by decreasing the flows of undocumented workers into the United States with new penalties on employers who hire illegal workers, and by giving new resources to the Border Patrol for enforcement initiatives along the U.S.-Mexico border. ${ }^{30}$

The employer-sanction portion of IRCA imposed civil fines on those who knowingly hired, recruited, or referred for a fee immigrants who were not authorized to work in the United States. It required that businesses obtain proof of citizenship such as a Social Security card, passport, or birth certificate from any potential employee. The fines for violations ranged from a maximum of $\$ 1,000$ per undocumented immigrant for a first offense to $\$ 10,000$ per worker. Harsher punishments can be imposed on repeat offenders. $^{31}$

The legalization aspect of IRCA was actually made up of two programs: one for people who had continuously resided in the United States since Jan. 1, 1982, and another for those who had worked as field laborers in perishable agricultural commodities for at least 90 days during the 12 -month period that ended May $1,1986 .{ }^{32}$

The general amnesty program had two phases, temporary and permanent residency. A one-year application period for temporary residency began May 5, 1987, and ended May 4, 1988. Applicants granted temporary residency had to apply for permanent residency within 30 months of their approval. If they did not apply, their temporary status expired, and they were subject to deportation. To move from temporary to permanent status, an immigrant must have had continuous residency in the United States, be admissible as an immigrant, and demonstrate a minimal understanding of English, U.S. government and American history. ${ }^{33}$ There were a few exceptions to this process, and immigrants who had resided continuously in the United States since January 1, 1972, were allowed to bypass temporary residency.

The second legalization program, the Special Agricultural Worker initiative, allowed for the temporary residency of field workers; however, adjustment to permanent status was essentially automatic under the Immigration and Nationality Act. The 18-month application period began June 1, 1987, and ended November 30, $1988 .{ }^{34}$ Workers who qualified and were outside of the United States could apply at U.S. consulates in Mexico or at border entry stations in Calexico, Califrnia; Otay Mesa, California; or Laredo, Texas. $^{35}$

Before the deadlines in 1988, 3.1 million applications for legalization had been filed: 1.8 million in the general amnesty program and 1.3 million in the agricultural one. ${ }^{36}$ (Under the agricultural program, 10,906 applications were filed at U.S. consulates, and 139,959 at the three border stations. ${ }^{37}$ ) Mexicans constituted about 70 percent of the people granted amnesty in the general program and 80 percent of those who were given legal status as farm workers. ${ }^{38}$ About 2.3 million Mexicans, predominantly men, received legal papers under IRCA's two legalization programs. This wave of legalization was 
then followed by an "echo" of legal migration from Mexico as the men sponsored the entry of their wives and daughters. 39

Interestingly, Cerrutti and Massey also found evidence of an increase in documented migration by men from Mexico after IRCA passed, lasting to about 1992. Although the legalization programs were designed to apply only to people who were already in the country, Cerrutti and Massey attribute this peak to fraud within both initiatives. "The agricultural worker program, in particular, seems to have been so loosely administered and so nebulous in its criteria for qualifications that it induced some Mexicans to cross the border in hopes of being legalized," they write. One study found that in California, the number of applicants for legalization in the program was three times the size of the state's entire agricultural work force during that time. ${ }^{40}$

Despite the fact that the goal of IRCA was to limit immigration to the United States, the entry numbers continued to grow after the legislation passed. This may have occurred for several reasons. Some scholars of Mexican migration argue that major factors include the wave of secondary immigration that occurred as a consequence of IRCA's legalization elements, which allowed formerly undocumented immigrants to sponsor their relatives for papers, lack of serious efforts to enforce the hiring limitations in the law, and the apparent failure of the new border enforcement efforts to deter migrants from entering the country. ${ }^{41}$

\section{After IRCA}

Post-IRCA migration trends were heavily influenced by several major events, including the 1990 Immigration Act, the passing of NAFTA in 1994 and the Mexican financial crisis of 1994-1995, the 1996 Illegal Immigration Reform and Immigrant Responsibility Act, and the financial crisis of 2008. It should be noted that while several immigration reforms passed during the 1990s, Congress failed to agree on any substantial immigration legislation during the decade of the 2000s, and the only real change in migration patterns occurred due to unintended forces such as the global financial crisis of 2008 and ensuing worldwide recession.

The period between 1980 and the early 2000s was a time of unprecedented growth in the Mexican population living in the United States. According to the U.S. Bureau of the Census, the Mexican-born population living in the U.S. tripled from 1980 to $1995 .^{42}$ This growth accelerated to an even more rapid pace in the period after 1990, increasing the Mexican-born population from 7 million in 1997 to approximately 10 million in 2002, an increase of 43 percent in five years. ${ }^{43}$ By 2008, there were almost 12 million Mexicans living in the U.S. In addition to unknown levels of growth, this period saw a huge increase in the number of people emigrating from Mexico illegally. It is estimated that around 12 million unauthorized immigrants are currently living in the U.S., one million of whom came to the U.S. as children. ${ }^{44}$ While the estimates on the actual number of unauthorized immigrants living in the U.S. vary, the Migration Policy Institute estimates that in 2009, 62 percent of all undocumented immigrants were from Mexico. ${ }^{45}$ 


\section{Immigration Act of 1990}

According to the U.S. Citizen and Immigration Services, Public Law 101-649 (the Immigration Act of November 29, 1990), "increased the limits on legal immigration to the United States, revised all grounds for exclusion and deportation, authorized temporary protected status to aliens of designated countries, revised and established new nonimmigrant admission categories, revised and extended the Visa Waiver Pilot Program, and revised naturalization authority and requirements." ${ }^{46}$ The 1986 IRCA legislation dealt primarily with unauthorized immigration: granting legal status to unauthorized immigrants, increasing border control and imposing harsher penalties for employers who hire undocumented workers. The Immigration Act of 1990, sponsored by Sen. Edward Kennedy (D-MA) and Rep. Bruce Morrison (D-CT), was the most comprehensive reform in legal immigration since the 1965 Hart-Celler Act. ${ }^{47}$

While the basic foundation of the 1965 law remained intact as the new legislation's core principles, many of these principles were added upon, at the same time that the 1990 Act ushered in some significant changes. For example, the 1990 law provided new immigration opportunities for potential immigrants originating from countries that historically had sent few migrants to the United States. These "diversity immigrants" were to migrate from countries of the world previously underrepresented in the U.S. immigration pool. ${ }^{48}$ This type of immigrant was allowed entry based on a lottery system. The first time a lottery system was ever enacted as part of immigration legislation, the 1990 Act allowed for up to 40,000 visas under this category between the years of 1992 to 1994 , and increased the ceiling to 55,000 in subsequent years. ${ }^{49}$

In addition to the creation of diversity visas, another important aspect of the 1990 legislation was the change in upper limits for the number of family-based and work-based visas granted. $^{50}$ For example, the limit on family-based immigration was raised from 216,000 to 480,000 annually. ${ }^{51}$ Overall, the ceiling on all categories of visas was raised from 270,000 under previous legislation to 675,000 in 1995 , after a brief period of transition when the cap was 700,000. ${ }^{52}$ In addition, each of the different quotas for various types of immigrants (for example, adult siblings of citizens, adult unmarried children of legal permanent residents, unskilled workers) was modified. One noted increase was in employment-based immigration. Seen as an objective of the legislation, the Act created a large increase in employment-based immigration ${ }^{53}$ (from 54,000 to 140,000 annually). ${ }^{54}$

One other important feature of the 1990 Act was that it granted legal permanent residence status to up to 165,000 spouses and minor children of immigrants that received amnesty under IRCA, and it also doubled the number of immigrants seeking asylum allowed to obtain permanent legal status to 10,000 per year. ${ }^{55}$

\section{Restrictions on Access to Social Services for the Undocumented}

The period of the early 1990s was a time when unauthorized immigrants faced more restrictive policies and punishments, while outside economic and political factors 
continued to lead to a large expansion in the number of immigrants arriving from Mexico without documents. During this time period, both state and federal legislation was passed that intended to punish illegal immigrants and restrict their access to social services across the nation.

In 1994, California passed Proposition 187, which greatly restricted unauthorized immigrants' access to the state's social safety net. ${ }^{56}$ Proposition 187 denied the undocumented access to California's public schools and medical care, as well as other social services, and also made mandatory the reporting of suspected illegal immigrants by law enforcement official and public employees to the Immigration and Naturalization Service. ${ }^{57}$ Because they are considered public employees, under Proposition 187 teachers and healthcare workers were required to report any individuals, including children, they suspected were in the state without the proper documentation. The Proposition, referred to as the "Save Our State" initiative, was ultimately deemed unconstitutional and was overturned in 1999 after its implementation was held up in courts for years. ${ }^{58}$ However, the fact that these restrictive policies against undocumented aliens, which would have potentially denied children the right to a public education and basic healthcare based on their country of birth, were passed in the state that has the largest percentage of Mexican immigrants in the country (37.3 percent of all Mexican immigrants to the U.S. resided in California in $2008^{59}$ ) speaks loudly about the national climate regarding undocumented workers in the 1990s, which eventually resulted in the 1996 legislation outlined below.

Other restrictions on illegal immigrants' use of social services came from the federal government. In 1996, President Clinton signed three important pieces of legislation affecting illegal immigrants in the U.S. ${ }^{60}$ The first of these was the Personal Responsibility and Work Opportunity Reconciliation Act, otherwise known as the Welfare Reform Act, which denied illegal immigrants access to Medicaid, food stamps,

Supplemental Security Income, and most other federal public benefit programs. ${ }^{61}$ It also denied legal immigrants access to these programs for at least the first five years of residence in the U.S. The second was the Illegal Immigration Reform and Immigrant Responsibility Act, which was a major immigration reform targeted at stemming illegal immigration, explained in more detail below. The third piece of legislation was the AntiTerrorism and Effective Death Penalty Act, which facilitated and made easier the arrest, detainment and deportation of undocumented immigrants. ${ }^{62}$

\section{Illegal Immigration Reform and Immigrant Responsibility Act of 1996}

While the Immigration Act of 1990 was focused on reforming legal immigration to the U.S., the Illegal Immigration Reform and Immigrant Responsibility Act of 1996 (IIRIRA) was the first legislation targeting the issue of illegal immigration since the passage of IRCA in 1986. After the enactment of IRCA, concern over illegal immigration to the U.S. persisted. During the 1990s, illegal immigration, largely originating from Mexico, continued to rise. The American public's perception that unauthorized immigration was a growing problem ultimately led to the passage of IIRIRA in 1996. Aimed at curbing illegal immigration to the country, IIRIRA was to be the "get tough on immigration" policy. Among other reforms, it included the allocation 
of more money directed at border enforcement activities, it sped up the deportation of unauthorized migrants (both without documents and those with fraudulent documents), it in turn banned the reentry of people who entered or attempted to enter the country without authorization, it increased the criminal penalties paid by unauthorized immigrants, it imposed harsher sanctions on employers of undocumented workers, and it promoted inter-governmental cooperation of enforcement agencies on the federal, state and local levels. ${ }^{63}$ In sum, the bill focused on stricter penalties for immigration-related offences and more resources directed at border enforcement and unauthorized immigrant detention and expedited deportation.

\section{Political and Economic Forces Driving Migration out of Mexico}

Despite restrictive policies and legislation passed on the federal and state levels during the 1990s, illegal migration out of Mexico to the U.S. continued with rapidly increasing numbers. In 2008, the Pew Hispanic Center estimated that there were 11.9 million undocumented immigrants residing in the U.S., with 8.3 million of them in the U.S. labor force. ${ }^{64}$ They also estimate between 1990 and 2006, the unauthorized immigrant population grew significantly, but has since then dropped off. ${ }^{65}$ According to the Pew Hispanic Center's calculations, a majority of Mexican immigrants in the U.S. are illegal, and up to 85 percent of immigrants who have arrived in the past 10 years are undocumented. ${ }^{66}$ However, other data collection agencies estimate illegal immigration numbers to be much lower.

The increase in illegal immigration, much of which comes from Mexico, can be viewed largely as a consequence of policies restricting the number of legal immigrants granted visas, coupled with unrelated economic and demographic issues affecting Mexico during this time period. Because of high fertility rates in the 1960s and 1970s, there was a large growth in the 15- to 35-year-old population that the Mexican economy was not well prepared to absorb, especially in light of the continuing migration from rural to urban areas. More recently, fertility rates in Mexico have approached those of the U.S.

\section{The North American Free Trade Agreement}

The North American Free Trade Agreement (NAFTA) had arguably important unintended effects on migration out of Mexico. While the Mexican economy continued to grow during the period immediately after the passage of NAFTA and it is generally accepted among economists that NAFTA resulted in an overall reduction in poverty in Mexico, the positive effects of this growth did not always trickle down to average Mexicans. Actually, many small-business owners and laborers in several sectors of the economy were negatively affected by the reforms imposed by NAFTA. While NAFTA benefitted the large-scale farming industry, many small-scale farms and agriculture workers could no longer compete with lowered prices and the influx of American goods associated with the reduction in tariffs and subsidies prompted by NAFTA, and were forced out of business. This resulted in a large numbers of displaced workers in agriculture, which likely led to increased migration to the U.S. ${ }^{67}$ Moreover, NAFTA called for the privatization of collective farms in Mexico, thus further increasing the 
number of workers displaced by the neoliberal policies who began to seek employment and opportunity in the north. ${ }^{68}$ NAFTA attempted to integrate the markets and economies of North America, open its borders to the free flow of goods, and expand capital investment opportunities, but it ignored the integration of the labor market between Mexico and the U.S. by almost completely ignoring the issue of worker mobility. ${ }^{69}$ Patricia Fernandez-Kelly and Douglas Massey point out that the European Union, while integrating its market, paid careful attention to "harmonize social policies, equalize economic infrastructures, and guarantee worker rights and mobility within the trade zone." ${ }^{, 70}$ Directly contrasting the policies adopted by the European Union to smooth the transition to an integrated trade zone, NAFTA included no such provisions and allowed the U.S. to maintain its restrictive border policies, and did nothing to grant more immigration rights to Mexican workers affected by the legislation. ${ }^{71}$ No significant legislation was passed in the U.S. to allow for an increase in migration out of Mexico, and an increase in illegal immigration occurred.

\section{Enhanced Border Security}

The era of NAFTA led to a change in the migration patterns between the U.S. and Mexico in another important way. As legislation allowed for greater resources to be devoted to controlling the entry of unauthorized immigrants and did little to address the need for increased ceilings on the number of legal visas granted, the U.S. began drastically increasing the money spent on attempting to stem illegal immigration. Moreover, also in 1993, the U.S. Border Patrol launched an enforcement strategy called Operation Blockade on the El Paso-Ciudad Juarez border crossing, and then Operation Gatekeeper, a similar strategy on the San Diego-Tijuana section of the international border in the following year. ${ }^{72}$

Stricter and more comprehensive border control strategies caused Mexican illegal immigrants to become more likely to stay in the U.S. in order to avoid the risk of detention associated with the elevated level of border control. ${ }^{73}$ Beginning with the original restrictions on immigration that passed with IRCA in 1986, these restrictions became more and more strict throughout the 1990s and 2000s. The increased border security and harsher criminal punishments that came with legislation in the 1990s led to a significantly decreased amount of cyclical migration, causing many temporary migrants to become permanent undocumented residents. ${ }^{74}$ Because an increased percentage of previously temporary migrants became permanent undocumented residents, the number of Mexicans living in the U.S. reached a previously unknown high.

The fact that more immigrants were becoming settled in the U.S. and less migration between countries was taking place had another unintended consequence on the make-up of Mexican migration to the United States: an increased number of women began migrating to join their husbands on the other side of the border, a large number of whom migrated illegally. ${ }^{75}$ From 1980 to 1986 , women made up approximately 48 percent of legal immigrants, but from 1991 to 1996 , their share had jumped to 59 percent. ${ }^{76}$ While undocumented immigrants traditionally had been primarily men who followed cyclical 
migration patterns, families which migrated to the U.S. to stay began to represent the majority of illegal immigrants.

\section{The Mexican Financial Crisis and Peso Devaluation}

Another factor contributing to increased migration northward from Mexico was the financial crisis and peso devaluation that occurred in the end of 1994. While the causes of the crisis were complex and are beyond the scope of this paper, its effects greatly incentivized potential migrants to seek work in the U.S. In sum, the 1994 financial crisis in Mexico led to a drastic plunge in the value of the peso, greatly adding to the economic benefits of earning wages in dollars relative to Mexican pesos. Therefore, with a dramatically devalued peso, large numbers of immigrants ventured to the U.S. to take advantage of the increased value of the dollar. Sending remittances home in dollars became suddenly more lucrative in the face of a devalued peso. When the peso lost value relative to the dollar, unauthorized migrants were more likely to leave Mexico and seek more profitable employment in the U.S.

\section{The Bush Administration Years: 2000-2008}

As a former governor of one of the states with the largest number of Mexican immigrants in the U.S., George W. Bush came to the presidency with an understanding of the need for comprehensive immigration reform. However, because of the highly political and contentious nature of the issue, the inability to mobilize Congress behind an immigration reform bill and the distractions of the September 11, 2001, attacks and subsequent beginning of the global war on terrorism, any push for comprehensive immigration reform was pushed to the back of the political agenda during the 2000s. During this period, the U.S. took a defensive and punishment-oriented stance on immigration, increasing resources dedicated to border enforcement and control, and stricter punishment for unauthorized presence in the country. Some minor legislation focused on immigration was passed, but it was primarily focused on these areas, instead of on any large-scale reform.

In spite of increased resources devoted to stemming the tide of illegal immigrants arriving across the 2,000 mile-long U.S.-Mexico border, the number of both legal and illegal immigrants continued to rise. The outflow of migrants from Mexico was seemingly not affected by these "get tough" immigration policies. The slowing of outmigration from Mexico did not begin to occur until immigrants began to lose the economic incentive to do so in the months leading up to the financial crisis of 2008 and the global economic downturn that followed.

\section{Financial Crisis}

According to a Migration Policy Institute analysis, the foreign-born population residing in the U.S. began to experience a slower rate of growth in 2007, due to the early consequences of the 2008 financial crisis. ${ }^{77}$ Legal immigration is less subject to the economic fluctuations in immigrant-receiving countries than is unauthorized migration, 
and the U.S. began to see a stagnant growth in illegal immigration due in part to the 2008 financial crisis. ${ }^{78}$ Because of the risks associated with illegal border crossings, illegal immigration became less of a viable option for Mexicans and other potential unauthorized immigrants due to decreases in demand in the U.S. labor market. Further, unauthorized migrants are more closely tied to the labor market than legal permanent residents because most of the unauthorized migrate for work reasons, while the majority of legal permanent residents are admitted for family ties. In 2008, only 15 percent of new visas were granted for employment reasons. Because new visas are granted mostly for family and not employment reasons, and because the small amount of new visas granted each year are highly oversubscribed (people often wait for years to acquire a visa), the flow of legal immigrants is not generally affected by the fluctuations in the U.S. economy, thus the U.S. has not experienced a slowdown in numbers of new legal permanent residents migrating to the country during the current recession. ${ }^{79}$

\section{Characteristics of Migrants}

Historically, migrants from Mexico have primarily been males who have participated in cyclical migration patterns, heading north to work and returning to Mexico according to seasonal variations and changes in labor demand.

Although a common perception among some Americans may be that migrants are fleeing dire poverty in Mexico to try to make permanent homes in the United States, scholars Jorge Durand and Douglas Massey argue that that view is flawed. They describe the decision to migrate as generally an "adaptive strategy to compensate for missing and failed markets in Mexico." They say the majority of migrants plan to return to Mexico while working in the United States for short periods for money that serves as an alternative income stream in their households or allows them to build up savings for reasons such as buying a home. As evidence of the temporary migration strategy, the researchers point to the long-enduring trend of male migrants leaving behind their families. However, migration by women and children has become more common in recent years. ${ }^{80}$

The traditional sources of migration have been states in the central and western areas of Mexico-including Guanajuato, Jalisco, Michoacan, Zacatecas, and San Luis Potosibut in recent years, many other states, including those in southern Mexico such as Veracruz and Oaxaca, have experienced higher volumes of migration to the United States.

To investigate the geographic sources and destinations of migrants from Mexico, we analyzed data from ethnosurveys conducted by the Mexican Migration Project since 1982. The data is based on the responses of 7,112 heads of households in 124 Mexican communities and their branch settlements in the United States. The Mexican Migration Project, a collaborative research initiative based at the Princeton University and the University of Guadalajara, began gathering data in the traditional migration areas of Mexico but has expanded its collection sites to states in the north and south. Within each state, the researchers employed a number of sampling techniques and selected 
communities with a range of sizes, from rural villages to major metropolitan centers. However, because the communities were not selected randomly, the data is not representative of all of Mexico. Technically, the samples can represent only the communities from which they were taken. ${ }^{81}$ However, the Mexican Migration Project offers important insights into the lives of migrants and has been widely used by researchers.

According to our analysis, migrants most frequently identified the following Mexican states as their place of birth: Jalisco (19 percent), Guanajuato (14 percent), Michoacán (14 percent), Zacatecas (11 percent), and San Luis Potosi (8 percent). Among those migrants who were older than 50, legal residents of the United States and had spent at least 120 months in the U.S., the most common states of birth were Jalisco ( 29 percent), Michoacán (21 percent), Zacatecas (14 percent), Guanajuato (13 percent) and San Luis Potosi (6 percent). The age distribution of the migrants included in the sample are:

- 17 to 25: 6 percent,

- 26 to $35: 24$ percent,

- 36 to $45: 25$ percent,

- 46 to $55: 18$ percent, and

- 55 and over: 27 percent.

In the United States, the traditional destinations for Mexican migrants were three border states-Texas, Arizona, and California-as well as Illinois. However, in the late 1990s, more immigrants began settling in new destinations. From 1990 to 2002, the proportion of Mexican immigrants living in the four traditional states fell from 89 percent to 72 percent. During that time, some Mexicans who had moved to the traditional states began to leave those, especially California, for areas of the southeastern part of the country, attracted by jobs in poultry processing, light manufacturing, and construction. In areas of the upper Midwest, jobs in pork, beef and turkey processing were the draw. In all, the Mexican immigrant population outside the four traditional states shot up from about 500,000 to 2.7 million between 1990 and 2002. ${ }^{82}$ However, according to the 2008 census data, 70 percent of the Mexican-born residing in the U.S. live in the four traditional states.

The head-of-households data from the Mexican Migration Project illustrate the long-term trend of migration to the traditional states. The top states of immigration for the whole sample were California (53 percent), Texas (15 percent), Illinois (9 percent), Arizona (2 percent), and Florida (2 percent). Among those migrants who were older than 50, legal residents of the United States and had spent at least 120 months living in the United States, the top states of immigration were California (61 percent), Texas (10 percent), Illinois (11 percent), Florida ( 3 percent) and Arizona (2 percent). 


\section{Structure of the Mexican-born in the U.S.}

In the case of Mexico and the U.S., two major events occurred in the past two decades that encouraged Mexican-born people to become U.S. citizens. First, the Mexican government changed its laws in 1998 to allow Mexicans to become dual citizens. Before this law passed, Mexicans had to renounce their Mexican citizenship upon becoming a citizen of another country. By allowing dual-citizenship, many Mexicans residing in the United States were encouraged to naturalize as U.S. citizens and thus ease their open travel between the two countries. Second, the U.S. government added an exception to the rule that all people seeking citizenship must take the civics portion of the citizenship test in English. This exception affects older immigrants who have lived in the U.S. an extended period of time but have limited English proficiency. The exception allows immigrants who are 50 and over and who have lived in the U.S. for 20 years to take the civics portion of the test in their native language, and residents who are 55 and older who have lived in the U.S. for 15 years are granted the same exception.

All the forces mentioned above, coupled with socioeconomic and demographic factors arising out of Mexico, have resulted in the structure of the Mexican-born in the U.S. that we see today. The Census Bureau estimates that in 2008, the latest year for which data are available, about 12 million Mexican-born people were residing in the United States, 2.5 million of whom were naturalized citizens. This estimate did not include the unknown number of legal permanent residents and Mexican-born U.S. citizens who were residing in Mexico at the time of the census and therefore not included in the total. According to a Migration Policy Institute analysis of data from several government sources, there were about 3.4 million legal permanent residents in the United States who were born in Mexico. In 2008, 8.7 percent of the Mexican-born in the U.S. were minors, 78.4 percent were between the ages of 18 and 54 , and 12.9 percent were 55 or older. ${ }^{83}$ ACS data show that in 2008, 2.2 million of the Mexican-born population were 50 or older. Of those 2.2 million, about 950,000 were naturalized U.S. citizens. (The data did not include information on the number of older immigrants who were legal permanent residents.)

After over 100 years of immigration between the U.S. and Mexico, millions of Mexicanorigin immigrants live in the United States. With the accelerated migration trend of the past 30 years, there are millions who are documented and can move easily back and forth across the border, and millions who are undocumented and cannot. Of those who are undocumented, many have children who were born in the United States and are therefore U.S. citizens who will likely remain connected to both countries as they age. The Pew Hispanic Center estimates that 73 percent of children of undocumented immigrants in the U.S. are U.S. born and therefore citizens. ${ }^{84}$ Out of the almost 30 million people who identify themselves as Mexican-origin, approximately 12 million were born in Mexico, and a number of those have dual citizenship. Many of these dual citizens are older Mexicans who have spent many years in the U.S. labor force and are entitled to Medicare benefits, but these benefits are not accessible when they travel or retire to Mexico. Because many Mexicans in the United States maintain close ties with their Mexico, it is common for legal residents or dual citizens to spend part of their time in the United States 
and part of their time in Mexico, especially among older people who are retired. According to 2008 census data, it is estimated that 550,000 Mexican-born people in the United States age 50 and older are entitled to Medicare benefits. These beneficiaries must usually forgo their benefits while in Mexico and pay for any medical services out of pocket, thus often hindering their ability to retire to their native country.

While the flow of unauthorized migrants has slowed in the recent years because of factors mentioned above, the number of legal residents and U.S. citizens traveling between the two countries is rising. In line with current global trends toward "transnational citizens," more people are residing outside of their native countries as the movement of goods and people becomes more fluid worldwide. The future is likely to bring even more integration between the United States and Mexico, with increasing numbers of Mexicans becoming eligible to immigrate to the U.S. based on family connections and increasing numbers of dual-citizens and Mexican-origin U.S. citizens. Such an increase in the flow between the two countries will necessitate U.S. policies that encourage rather than inhibit the free flow of legal migrants. 


\section{Notes}

${ }^{1}$ Esmeralda Rodriguez-Scott, "Patterns of Mexican Migration to the United States" (paper presented to the 82nd annual meeting of the Southwestern Social Science Association, New Orleans, Louis., March 27-30, 2002), p. 4.

${ }^{2}$ Ibid.

${ }^{3}$ Jose Hernandez Alvarez, "A Demographic Profile of the Mexican Immigration to the United States, 19101950.” Journal of Inter-American Studies, vol. 8, no. 3 (1966), pp. 471-496. Online. Available: http://www.jstor.org/stable/165263. Accessed: April 11, 2010.

${ }^{4}$ Anne Pace, "Mexican Refugees in Arizona 1910-1911," Arizona and the West, vol. 16, no. 1 (1974), pp. 6-7. Online. Available: http://www.jstor.org/stable/40168223. Accessed: April 10, 2010.

${ }^{5}$ Robert McCaa, "Missing Millions: The Demographic Costs of the Mexican Revolution," Mexican Studies/Estudios Mexicanos, vol. 19, no. 2 (2003), p. 378. Online. Available: http://www.jstor.org/ stable/3557655. Accessed: April 10, 2010.

${ }^{6}$ Ibid., p. 379.

${ }^{7}$ Rodriguez-Scott, "Patterns of Mexican Migration to the United States," p. 5.

${ }^{8}$ Francisco Arturo Rosales, "The Regional Origins of Mexicano Immigrants to Chicago during the 1920's," Aztlan: A Journal of Chicano Studies, vol. 7, no. 2 (1976), pp. 187-201. Online. Available:

http://aztlanjournal.metapress.com/app/home/contribution.asp?referrer=parent\&backto=issue,4,11;journal,5 0,63;linkingpublicationresults,1:120206,1. Accessed: April 11, 2010.

${ }^{9}$ David Fitzgerald, "Inside the Sending State: The Politics of Mexican Emigration Control," International Migration Review, vol. 40, no. 2 (2006), pp. 259-293. Online. Available: http://ccis.ucsd.edu/wp-content/ uploads/2009/12/Fitzgerald-2006.IMR_.pdf. Accessed: April 11, 2010.

${ }^{10}$ Rosales, "The Regional Origins of Mexicano Immigrants to Chicago during the 1920s," p. 194.

${ }^{11}$ Rodriguez-Scott, "Patterns of Mexican Migration to the United States," p. 5.

${ }^{12}$ Ibid.

${ }^{13}$ Michelle Parrini, “The Braceros,” Insights on Law and Society, vol. 7, no. 2 (winter 2007), p. 27.

${ }^{14}$ Ibid.

${ }^{15}$ Ibid.

${ }^{16}$ Rodriguez-Scott, "Patterns of Mexican Migration to the United States," p. 5. 
${ }^{17}$ Marcela Cerrutti and Douglas S. Massey, "Trends in Mexican Migration to the United States, 1965 to 1995," in Crossing the Border: Research from the Mexican Migration Project, ed. Jorge Durand and Douglas S. Massey (New York: Russell Sage Foundation, 2004), p. 17.

${ }^{18}$ Rodriguez-Scott, "Patterns of Mexican Migration to the United States," p. 6.

${ }^{19}$ Cerrutti and Massey, "Trends in Mexican Migration to the United States, 1965 to 1995,” p. 17.

${ }^{20}$ Jorge Durand and Douglas S. Massey, "What We Learned from the Mexican Migration Project," in Crossing the Border: Research from the Mexican Migration Project, ed. Jorge Durand and Douglas S. Massey (New York: Russell Sage Foundation, 2004), p. 9.

${ }^{21}$ Cerrutti and Massey, “Trends in Mexican Migration to the United States, 1965 to 1995," p. 18.

${ }^{22}$ U.S. Congress, Congressional Budget Office, "Immigration Policy in the United States," February 2006, p. 1.

${ }^{23}$ Cerrutti and Massey, "Trends in Mexican Migration to the United States, 1965 to 1995," p. 18.

${ }^{24}$ Ibid., p. 25.

${ }^{25}$ Ibid., p. 18.

${ }^{26}$ B. Lindsay Lowell, Carla Pederzini Villareal, Jeffrey S. Passel, "The Demography of Mexico-U.S. Migration," in Mexico-U.S. Migration Management: a Binational Approach, ed. Agustin Escobar Latapi and Susan Forbes Martin (Lanham, MD: Lexington Books, 2008), pp. 1-2.

${ }^{27}$ Belinda Reyes, "The Impact of U.S. Immigration Policy on Mexican Unauthorized Immigration," The University of Chicago Legal Forum, vol. 2007, pp. 135-136.

${ }^{28}$ Lowell, Pederzini Villareal, Passel, “The Demography of Mexico-U.S. Migration,” p. 4.

${ }^{29}$ Reyes, “The Impact of U.S. Immigration Policy on Mexican Unauthorized Immigration,” pp. 135-136.

${ }^{30}$ Frank D. Bean, Barry Edmonston, Jeffrey S. Passel, Undocumented Migration to the United States (Rand Corporation: Santa Monica, Calif., and The Urban Institutue: Washington, 1990), p. 2.

${ }^{31}$ Francisco L. Rivera-Batiz, "Introduction," in U.S. Immigration Policy Reform in the 1980s, ed. Francisco L. Riveral-Batiz, Selig L. Sechzer and Ira N. Gang (New York: Praeger Publishers, 1991), p. 3.

${ }^{32}$ Ibid.

${ }^{33}$ Michael D. Hoefer, "Background of U.S. Immigration Policy Reform," in U.S. Immigration Policy Reform in the 1980s, ed. Francisco L. Riveral-Batiz, Selig L. Sechzer and Ira N. Gang (New York: Praeger Publishers, 1991), p. 22. 
${ }^{34}$ Ibid., p. 23.

${ }^{35}$ Ibid., p. 25.

${ }^{36}$ Rivera-Batiz, "Introduction," p. 8.

${ }^{37}$ Hoefer, "Background of U.S. Immigration Policy Reform," p. 26.

${ }^{38}$ Cerrutti and Massey, “Trends in Mexican Migration to the United States, 1965 to 1995,” p. 20.

${ }^{39}$ Ibid., p. 41.

${ }^{40}$ Ibid., p. 25

${ }^{41}$ Lowell, Pederzini Villareal, Passel, “The Demography of Mexico-U.S. Migration,” p. 4.

${ }^{42}$ Patricia Fernandez-Kelly and Douglas Massey, "Borders for Whom? The Role of NAFTA in Mexico-US Migration," The ANNALS of the American Academy of Political and Social Science, vol. 610 (2007), p. 113. Online. Available: http://ann.sagepub.com/cgi/content/abstract/610/1/98. Accessed: April 10, 2010.

${ }^{43}$ Ibid., p. 113.

${ }^{44}$ Fernandez-Kelly and Massey, "Borders for Whom? The Role of NAFTA in Mexico-US Migration," p. 113.

${ }^{45}$ Aaron Terrazas, "US in Focus: Mexican Immigrants in the United States," Migration Information Source, Migration Policy Institute (2010) Online. Available: http://www.migrationinformation.org/ USfocus/display.cfm?id=767. Accessed: April 10, 2010.

${ }^{46}$ U.S. Citizenship and Immigration Services, Immigration Act of 1990. Online. Available: http://www.uscis.gov/portal/site/uscis/menuitem.5af9bb95919f35e66f614176543f6d1a/?vgnextoid=84ff95c 4f635f010VgnVCM1000000ecd190aRCRD\&vgnextchannel=b328194d3e88d010VgnVCM10000048f3d6a 1RCRD. Accessed: April 10, 2010.

${ }^{47}$ Michael Greenwood and Fred Ziel, "The Impact of the Immigration Act of 1990 on U.S. Immigration," US Commission on Immigration Reform (1997), p. 1. Online. Available: http://migration.ucdavis.edu/ mn/cir/Greenwood/combined.htm. Accessed: April 10, 2010.

${ }^{48}$ Ibid., pp. 2-3.

${ }^{49}$ Numbers USA, Immigration Act of 1990. Online. Available: http://www.numbersusa.com/text?ID=210. Accessed: April 10, 2010.

${ }^{50}$ Ibid.

${ }^{51}$ Ibid. 
${ }^{52}$ Greenwood and Ziel, “The Impact of the Immigration Act of 1990 on U.S. Immigration,” p. 2.

${ }^{53}$ Ibid., p. 4.

${ }^{54}$ Numbers USA, Immigration Act of 1990. Online. Available: http://www.numbersusa.com/text?ID=210. Accessed: April 10, 2010.

${ }^{55}$ Ibid.

${ }^{56}$ Migration Information Source, A New Century: Immigration and the US. Online. Available: http://www.migrationinformation.org/Profiles/display.cfm?ID=283. Accessed: April 10, 2010.

${ }^{57}$ Ibid.

${ }^{58}$ American Civil Liberties Union, CA's Anti-Immigrant Proposition 187 is Voided, Ending State's 5-Year Battle with ACLU, Rights Groups. Available: http://www.aclu.org/immigrants-rights/cas-anti-immigrantproposition-187-voided-ending-states-five-year-battle-aclu-righ. Accessed: April 10, 2010.

${ }^{59}$ Aaron Terrazas, "US in Focus: Mexican Immigrants in the United States," Migration Information Source, Migration Policy Institute, (2010) Online. Available: http://www.migrationinformation.org/USfocus/display.cfm?id=767. Accessed: April 10, 2010.

${ }^{60}$ Migration Information Source, A New Century: Immigration and the US. Online. Available: http://www.migrationinformation.org/Profiles/display.cfm?ID=283. Accessed: April 11, 2010.

${ }^{61}$ Ibid.

${ }^{62}$ Ibid.

${ }^{63}$ Katharine Donato, Chizuko Wakabayashi, Shirin Hakimzadeh and Amada Armenta, "Shifts in Employment Conditions of Mexican Migrant Men and Women: The Effect of U.S. Immigration Policy," Work and Occupations, vol. 35 (2008), p. 465. Online. Available: http://wox.sagepub.com/cgi/content/ abstract/35/4/462. Accessed: April 2, 2010.

${ }^{64}$ Jeffery Passel and D'Vera Cohn, "A Portrait of Unauthorized Immigrants in the United States," Pew Hispanic Center (2008), p. ii. Online. Available: http://pewhispanic.org/reports/report.php?ReportID=107. Accessed: April 2, 2010.

${ }^{65}$ Ibid., p. ii.

${ }^{66}$ Passel and Cohn, "Mexican Immigrants: How Many Come? How Many Leave?" Pew Hispanic Center (2009), p. iii. Online. Available: http://pewhispanic.org/files/reports/112.pdf. Accessed: April 2, 2010.

${ }^{67}$ Fernandez-Kelly and Massey, "Borders for Whom? The Role of NAFTA in Mexico-US Migration," pp. 105-106. 
${ }^{68}$ Ibid., p. 99.

${ }^{69}$ Ibid., p. 105.

${ }^{70}$ Ibid., p. 99.

${ }^{71}$ Ibid.

${ }^{72}$ Ibid., p. 107.

${ }^{73}$ Donato, Wakabayashi, Hakimzadeh, and Armenta, "Shifts in Employment Conditions of Mexican Migrant Men and Women," p. 467.

${ }^{74}$ Belinda Reyes, "The Impact of U.S. Immigration Policy on Mexican Unauthorized Immigration." The University of Chicago Legal Forum, vol. 2007 (2007), p. 140. Online. Available: http://heinonline.org/ HOL/LandingPage?collection=journals\&handle=hein.journals/uchclf2007\&div=7\&id=\&page. Accessed: April 10, 2010.

${ }^{75}$ Donato, Wakabayashi, Hakimzadeh, and Armenta, "Shifts in Employment Conditions of Mexican Migrant Men and Women," p. 467.

${ }^{76}$ Ibid.

${ }^{77}$ Demetrios Papademetriou and Aaron Terrazas, "Immigrants and the Current Economic Crisis: Research Evidence, Policy Challenges, and Implications," Migration Policy Institute (2009) pp. 2-3, Online.

Available: http://www.migrationpolicy.org/pubs/lmi_recessionJan09.pdf. Accessed: April 12, 2010.

${ }^{78}$ Ibid., pp. 6-9.

${ }^{79}$ Ibid., p. 6.

${ }^{80}$ Durand and Massey, "What We Learned from the Mexican Migration Project," p. 6.

${ }^{81}$ Jorge Durand and Douglas S. Massey, "Appendix: The Mexican Migration Project," in Crossing the Border: Research from the Mexican Migration Project, ed. Jorge Durand and Douglas S. Massey (New York: Russell Sage Foundation, 2004), p. 330.

${ }^{82}$ Jeffrey Passel, "Mexican Immigration to the U.S.: That Latest Estimates," Migration Information Source, Migration Policy Institute, March 2004. Online. Available: www.migrationinformation.org/usfocus/ display.cfm?ID=208. Accessed: April 12, 2010.

${ }^{83}$ Terrazas, "US in Focus: Mexican Immigrants in the United States" (online).

${ }^{84}$ Passel and Cohn, "A Portrait of Unauthorized Immigrants in the United States," p. i. 
(this page intentionally left blank) 


\title{
Chapter 4. Mexican-American Immigration to the Dallas Fort-Worth Metroplex
}

\author{
by Robin Lynch
}

\section{Connectivity between DFW and Mexico}

The Dallas-Fort Worth Metroplex in North Texas is home to a large Mexican community and provides an example of the cross-border connectivity between these two countries. Our research focused on this metropolitan area because it has long been the home of many Mexican-born immigrants, and the population is increasing every year. In 2000, over 400,000 people in north Texas (consisting of Dallas, Tarrant, Collin, and Denton Counties) were born in Mexico. ${ }^{1}$ Our research in this area focused on the elderly Mexican population that has chosen the Metroplex as their place of residence. With our survey, we found a wide variety of reasons for people choosing this location to live, ranging from closeness to family to accessibility of benefits and ease of living. One common theme prevalent through many of the respondents is the continued connectivity to Mexico.

Texas has long been closely tied with Mexico; in fact, it was a state in the Republic of Mexico long before it was ever part of the United States. North Texas, in particular, has been a major international center for immigration, not just from Mexico, but from many parts of the world. After the passage of the 1965 Hart-Celler Act, which opened up more non-European immigration, Dallas became a hub for immigration from Asia, the Middle East, Africa, and all of Latin America. People came to Dallas on account of the economic boom of the 1970s and early 1980s that was largely attributed to "the creation of the Dallas-Fort Worth airport, the presence of a strong financial sector and a pattern of corporate relocation promoted by the city."2 Nowadays, Dallas continues to have strong ties with Mexico, with over 50 independent bus companies that provide transportation to interior parts of Mexico and the presence of Interstate 35, which has become a major corridor for the movement of goods back and forth between the two countries. ${ }^{3}$

\section{Settlement Patterns in DFW}

In the early 20th century, refugees from the Mexican Revolution settled in a part of the northwest side of downtown Dallas dubbed "Little Mexico," but this area never had a population of more than 10,000 people. The number of Mexicans living in DFW increased after World War II, and figures from the 1970 census, when it began asking for statistics on Hispanics, showed that 68,000 Hispanics were living in the city of Dallas. ${ }^{4}$ Although not all Hispanics are Mexican, many more statistics exist on the number of Hispanics in the Dallas area, and, according to Sanchez and Weiss-Armush, 85 percent of the Hispanic population is of Mexican origin. ${ }^{5}$ In the 1960s, Little Mexico began to fall apart, largely due to the construction of the Dallas North Toll Way cutting straight through this neighborhood, ${ }^{6}$ and was other areas in the Metroplex started seeing increased Hispanic populations including Oak Cliff (south side of the Trinity River), Bachman- 
Walnut Hill (northwest Dallas), and East Dallas. ${ }^{7,}$ Today, Dallas County ranks as the fifth largest population of Hispanic residents in the country. ${ }^{8}$ Figure 4.1 shows the number of Mexican-born people per census tract, with the largest concentrations in the Oak Cliff, Bachman-Walnut Hill, and East Dallas neighborhoods.

Figure 4.1

\section{Percentage of Mexican-Born Population per Census Tract in Dallas County, 2000}

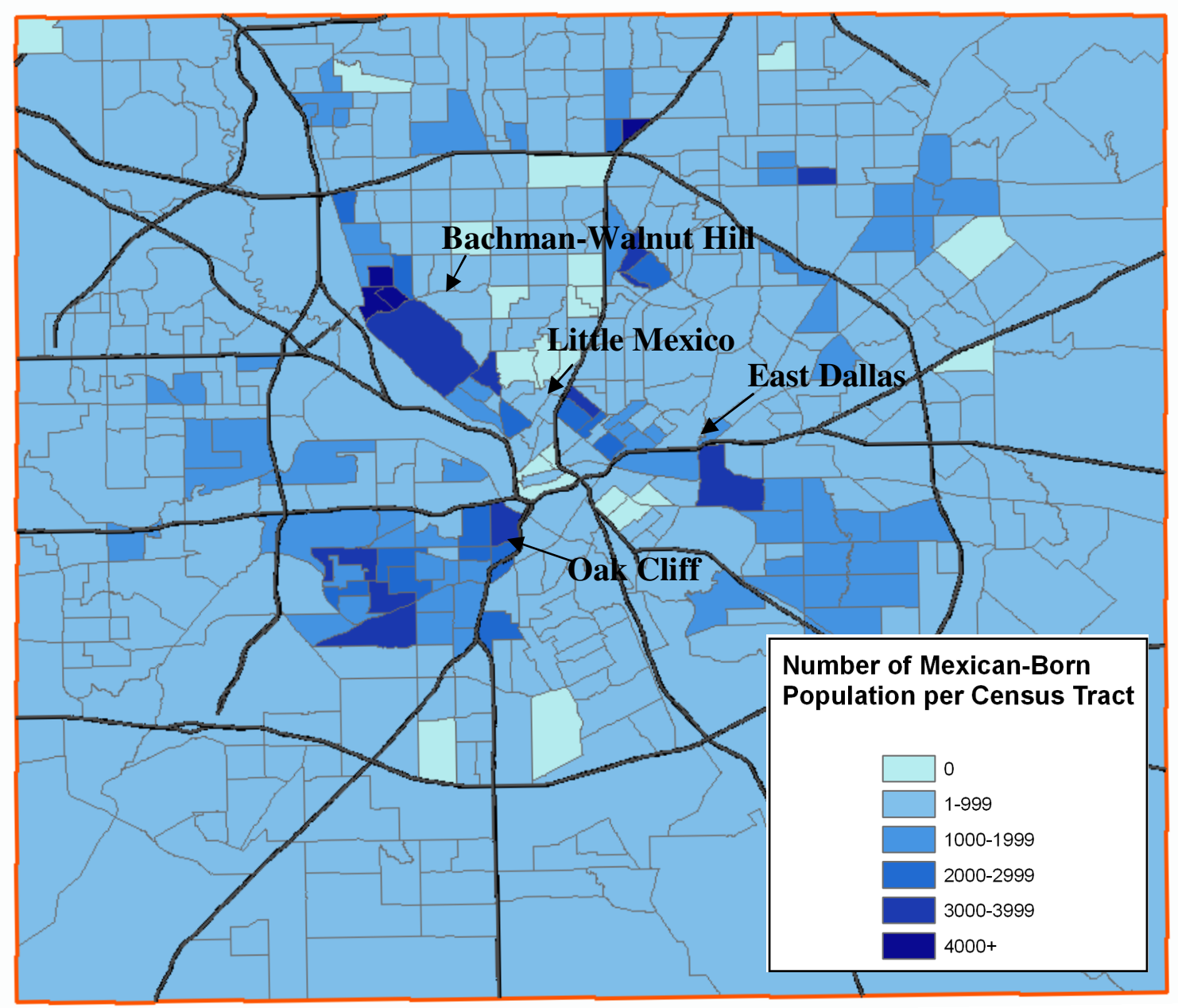

U.S. Census Bureau, "Census 2000 Summary File 4" database. Online. Available: http://factfinder.census.gov. Accessed: March 4, 2010. 
In addition, there are important clusters of the Hispanic population located in the surrounding cities, such as Irving, Grand Prairie, Arlington, Fort Worth (particularly on the north side), Carrollton, Richardson, Garland, and Mesquite. ${ }^{9}$ Figure 4.2 shows the number of Mexican-born population per census tract in Tarrant County, which contains Fort Worth.

\section{Figure 4.2 \\ Percentage of Mexican-Born Population per Census Tract in Tarrant County, 2000}

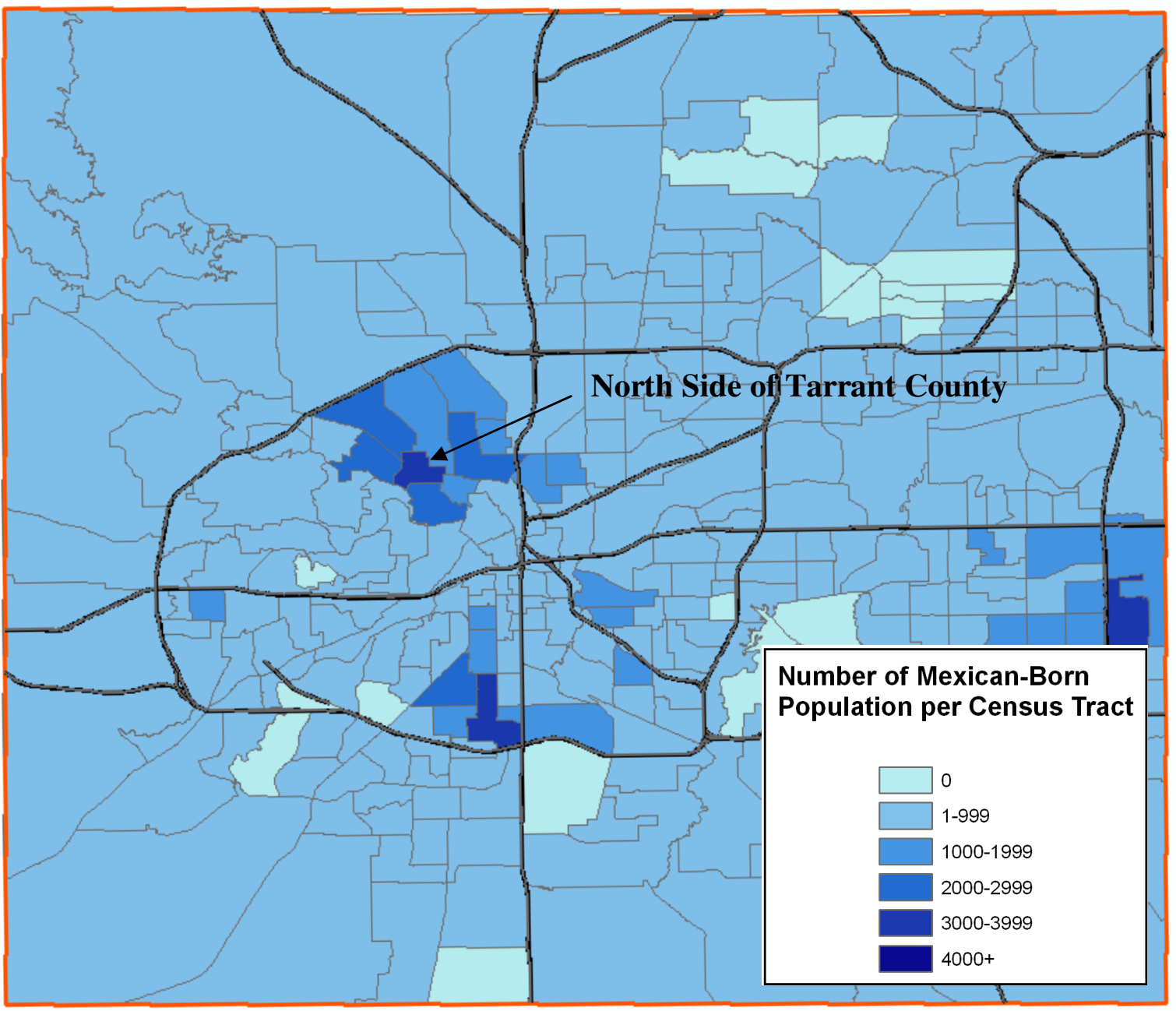

U.S. Census Bureau, "Census 2000 Summary File 4" database. Online. Available: http://factfinder.census.gov. Accessed: March 4, 2010. 
Figure 4.3 shows the relation of native-born and foreign-born populations in North Texas and, of those foreign-born, the proportion of Mexican-born, which is over 9 percent of the entire North Texas population.

Figure 4.3

\section{Native and Foreign Population in North Texas with Top Ten Immigrant Populations, 2000}

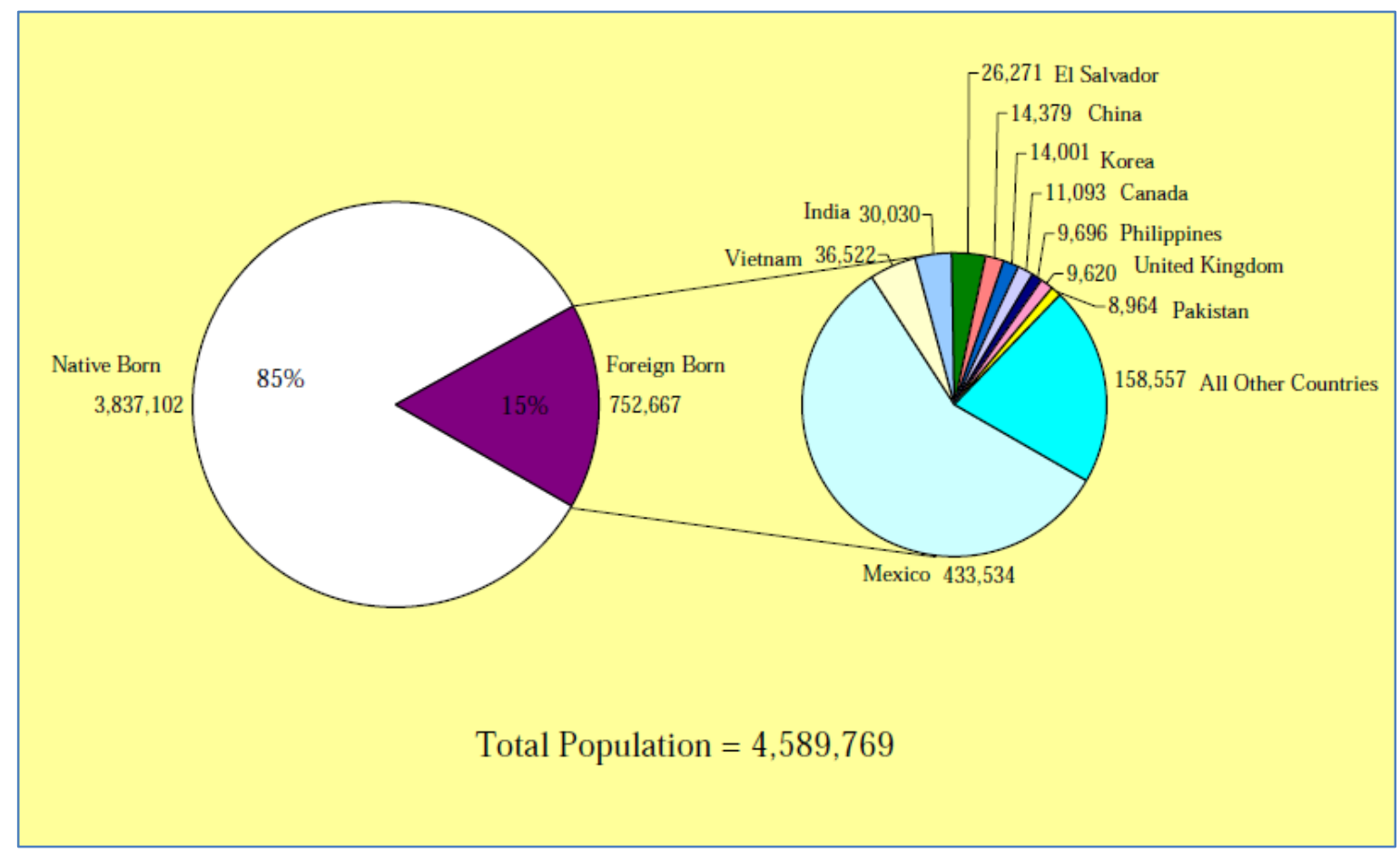

Source: Alonso Sanchez and Anne Marie Weiss-Armush, Study of North Texas Immigrant Communities (Dallas, Tex.: Dallas International, January 2003), p.31.

Since the 2000 census, the Mexican-born population has continued growing. According to the 2006-2008 American Community Survey three-year estimates, the Mexican-born population in North Texas was 584,887 people: 367,491 people in Dallas County were born in Mexico, 153,459 in Tarrant County, 33,137 in Collin County, and 30,800 in Denton County. This represents 15 percent of the population in Dallas County, 9 percent of the population in Tarrant County, 5 percent of Collin County, and 5 percent of Denton County.

\section{The Nature of Mexican Immigration to DFW}

According to the 2000 census, 65.8 percent of all immigrants in Dallas County are from Mexico. ${ }^{11}$ Of the immigrants from Mexico in the North Texas region, the Mexican 
Consulate estimates that, dividing immigration between each state of origin, 19 percent are from Guanajuato, 12.9 percent are from San Luis Potosí, 8 percent are from Zacatecas, 6 percent are from Durango, 5.6 percent are from Michoacán, 5.2 percent are from Distrito Federal (Mexico City), and 4 percent are from Nuevo Leon. ${ }^{12}$

Guanajuato, a state in central Mexico, was one of the earliest sources of Mexican migration to the United States. According to cemetery evidence in Texas, people from northeastern Guanajuato were living there by 1907, but researcher Laura Gonzalez believes that they were there before the railroads, in the late 1870s. ${ }^{13}$ Many parts of rural Guanajuato have noticeably fewer residents for the majority of the year while people work in the United States. In the summer, areas can look empty. But in the winter, migrants return home to celebrate with their families, and signs of the United States abound, including currency exchanges, license plates from U.S. states, and clothes bearing American sports team logos. ${ }^{14}$ The president of the organization Casa Guanajuato Dallas, Tereso Ortiz, says that "only women and children remain in his hometown of Ocampo, Guanajuato, because most of the Ocampo men are working in North Texas." "15 Many immigrants to Dallas did not come directly from Mexico, but rather through California. "As the president of the Federación de Zacatecanos del Norte de Texas (Zacatecan Federation from North Texas) explained, Texas was always a tough place to migrate to because the immigration authorities were stricter there than those in California. With legal status made possible after the 1986 amnesty, however, it became easier to move to Dallas, where not only real estate was cheaper than in California but jobs were more plentiful. ${ }^{16,}$

\section{The EIderly Mexican Community in DFW}

The elderly Mexican community is a small but growing part of the population in these counties. In the American Community Survey between 2006-2008, Dallas County had over 11,000 people born in Mexico who are over the age of 65, Tarrant County had over 4,000 people, Collin County had slightly under 500 people, and Denton County had slightly over 500 people. ${ }^{17}$ Many of these elderly Mexicans who were granted amnesty from IRCA decided to stay in the Dallas-Fort Worth Metroplex but will travel back to visit family on a regular basis. Mexicans living in Dallas often have close ties with their families and extended families back in Mexico. Many families will return back to Mexico once or twice a year, and families with school-age children will schedule these visits around school holidays like Christmas and summer. ${ }^{18}$ We conducted surveys with two organizations in the Dallas area providing help to the elderly Mexican community. We conducted surveys with La Voz del Anciano, a non-profit organization located in the Oak Cliff section of Dallas dedicated to fulfilling the needs of the elderly Latino community, and with the Brady Center, a senior center in East Dallas run by Catholic Charities to provide a social outlet and cheap meals for seniors. The results of these surveys are discussed in Chapter 8. 


\section{Notes}

${ }^{1}$ Alonso Sanchez and Anne Marie Weiss-Armush, Study of North Texas Immigrant Communities (Dallas, Tex.: Dallas International, January 2003), p. 8.

${ }^{2}$ Miryam Hazan, Incorporating in the United States and Mexico: Mexican Immigrant Mobilization and Organization in Four American Cities (Ph.D Diss., The University of Texas at Austin, 2006), p. 234.

${ }^{3}$ Robert V. Kemper, "Dallas-Fort Worth: Toward New Models of Urbanization, Community Transformation, and Immigration," Urban Anthropology, vol. 34, no. 2-3 (2005), p. 130.

${ }^{4}$ Hazan, Incorporating in the United States and Mexico, p. 231.

${ }^{5}$ Sanchez and Weiss-Armush, Study of North Texas Immigrant Communities, p. $6 .$.

${ }^{6}$ Rafael Rodriguez, Dallas North Tollway's Impact on Little Mexico. Online. Available: http://www.dallasblog.com/200710281000854/guest-viewpoint/dallas-north-tollway-s-impact-on-littlemexico.html. Accessed: March 20, 2010.

${ }^{7}$ Kemper, "Dallas-Fort Worth,” p. 135.

${ }^{8}$ Hazan, Incorporating in the United States and Mexico, p. 235.

${ }^{9}$ Kemper, "Dallas-Fort Worth," p. 135.

${ }^{10}$ U.S. Census Bureau, “American Community Survey 2006-2008” database. Online. Available: http://factfinder.census.gov. Accessed: March 30, 2010.

${ }^{11}$ Sanchez and Weiss-Armush, Study of North Texas Immigrant Communities, p. 71.

${ }^{12}$ Hazan, Incorporating in the United States and Mexico, p. 235.

${ }^{13}$ Laura Gonzalez, "Mexico/U.S. Migration and Gender Relations: The Guanajuatense Community in Mexico and the United States," in Gender, Globalization and Democratization, ed. Rita Mae Kelly, Jane H. Bayes, Mary E. Hawkesworth, and Brigitte Young (Lanham, Maryland: Rowman \& Littlefield Publishers Inc., 2001), pp. 81-82.

${ }^{14}$ Ibid., p. 82 .

${ }^{15}$ Sanchez and Weiss-Armush, Study of North Texas Immigrant Communities, p. 14.

${ }^{16}$ Hazan, Incorporating in the United States and Mexico, p. 235.

${ }^{17}$ U.S. Census Bureau, “American Community Survey 2006-2008” database. Online. Available: http://factfinder.census.gov. Accessed: March 30, 2010.

${ }^{18}$ Sanchez and Weiss-Armush, Study of North Texas Immigrant Communities, p 72. 


\title{
Chapter 5. Mexican-American Immigration to Los Angeles
}

\author{
by Andrea Haughton and Elizabeth Chmelik
}

\section{Mexican Immigrants in the Los Angeles area}

\section{Mexico-California Immigration in a Historical Context}

California has long had ties to Mexico. In the mid-19th century, it spent more than 20 years as a colony of the new republic after Mexico gained independence from Spain. And in the latter half of the 20th century, it became a major destination for immigrants from the nation to the south. Now, the U.S. state is home to an estimated 4.3 million people who were born Mexico.

Spaniards who traveled north from Mexico were the first people of European descent to settle in California, building a presence and attempting to convert Native Americans to Christianity. ${ }^{1}$ Their numbers remained small, however, and before the Gold Rush in the 1840s, they were outnumbered by Native Americans. After the Gold Rush, they were overtaken in population by immigrants from the rest of the United States.

At the beginning of the 20th century, only 10 percent of the 100,000 Mexicans living in the U.S. were in California, which had become a state in $1850 .{ }^{2}$ This soon changed after protectionist policies were passed that essentially cut off Asian immigration to the state, leaving agricultural jobs vacant. As a result, Mexican immigration to California increased, and by 1930, there were about 130,000 Mexicans residing there. ${ }^{3}$

However, the onset of the Great Depression and the westward migration of American farmers who were trying to escape the Dust Bowl led to higher unemployment and antiimmigrant sentiments in California. Similar to what had happened to Asian immigrants in previous years, immigration from Mexico was stemmed, and many Mexicans were deported. This resulted in the Mexican population of California dropping by one-third between 1930 and $1940 .^{4}$

The pendulum swung back the other way with the onset of World War II, when thousands of Mexicans were invited back into California under the Bracero program. This wave of Mexicans tended to settle in Southern California and the Central Valley, where the state's agriculture production was centered. ${ }^{5}$

Economic changes in the U.S. and social and economic factors in Mexico led to expansions and contractions in the Mexican population of California, but the end of the Bracero program had a significant, long-term impact on the composition of Mexican immigrants in the state. Braceros were traditionally male workers who left their families in Mexico while they migrated temporarily according to the growing season. As the Bracero program ended, many employers helped immigrants obtain documents that 
allowed them to reside permanently in California and eventually bring their families to join them. ${ }^{6}$

Overall, the Mexican population in California increased rapidly during the second half of the 20th century. In 1950, there were about 150,000 Mexicans in California; by 1980, there were approximately 1.3 million. ${ }^{7}$ The Los Angeles region became the epicenter of this growth.

\section{Mexican Immigrants in Los Angeles}

Originally a Mexican city, Los Angeles has historically had a large Mexican-origin population. While inflows from Mexico to California have declined in comparison to some other states in recent years, California remains the state with the largest percentage of Mexican immigrants; in 2008, 37.3 percent of all Mexican-born people living in the United States were in California. ${ }^{8}$ The final destination for many immigrants to California is the bustling metropolis of Los Angeles with its large Mexican community and supply of employment opportunities.

Los Angeles is home to the largest Mexican immigrant population outside of Mexico. East Los Angeles, the area east of the Los Angeles River and downtown, is home not only to the single-largest Mexican population in the country but also to the largest Hispanic community in the United States. ${ }^{9}$ East Los Angeles is the most well-known Mexican-origin community in the Los Angeles area, but Mexicans are increasingly moving to other areas, including South Central L.A., the San Fernando Valley and the San Gabriel Valley. ${ }^{10}$ Although growth in the Los Angeles area began to slow as the U.S. approached the 2008 economic crisis and recession, economic booms significantly increased the overall Mexican population in the past several decades.

It is estimated that 2.4 million Mexican-born people live in the four major counties of the Los Angeles area: Los Angeles, Orange, Riverside and San Bernardino Counties. ${ }^{11}$ Los Angeles County alone is home to more than 1.5 million people who were born in Mexico.

Researchers at the University of Southern California have made demographic projections for California to the year 2030. They estimate not only a rise in second-generation Americans, with 36 percent of children ages five to 14 being born to foreign-born parents, but they also believe that the foreign-born population is staying in the United States longer than previous generations. ${ }^{12}$ In 1980, people between the ages of 65 and 74 in California were mostly children of immigrants who had arrived in the early 20th century. According to USC's projections, the future elderly population is likely to be comprised of a larger percentage of foreign-born people who lived and worked in the U.S. for long periods. Today, 29.5 percent of the elderly in California are foreign-born; by 2030 , this figure is expected to exceed 40 percent. $^{13}$

\section{Political Environment}

Hometown associations and state federations are more plentiful in Los Angeles than in other states, primarily because of the large Mexican community and its historical roots in 
the city. In 2006, it is estimated that the Los Angeles metro area was home to 300 hometown associations, or HTAs, and 12 federations. ${ }^{14}$ The Federacion de Zacatecanos del Sur de California, created in 1986, was the nation's first state federation. ${ }^{15}$

We have identified six congressional districts in metropolitan Los Angeles that have large Mexican-born populations and a meaningful number of elderly residents who were born in Mexico. (These numbers are detailed in AppendixA.) The importance of the portability of health care benefits will only increase in the future.

\section{Figure 5.1}

\section{Congressional Districts in Metropolitan Los Angeles Showing Number of Mexican-Born Population per Census Tract, 2000}

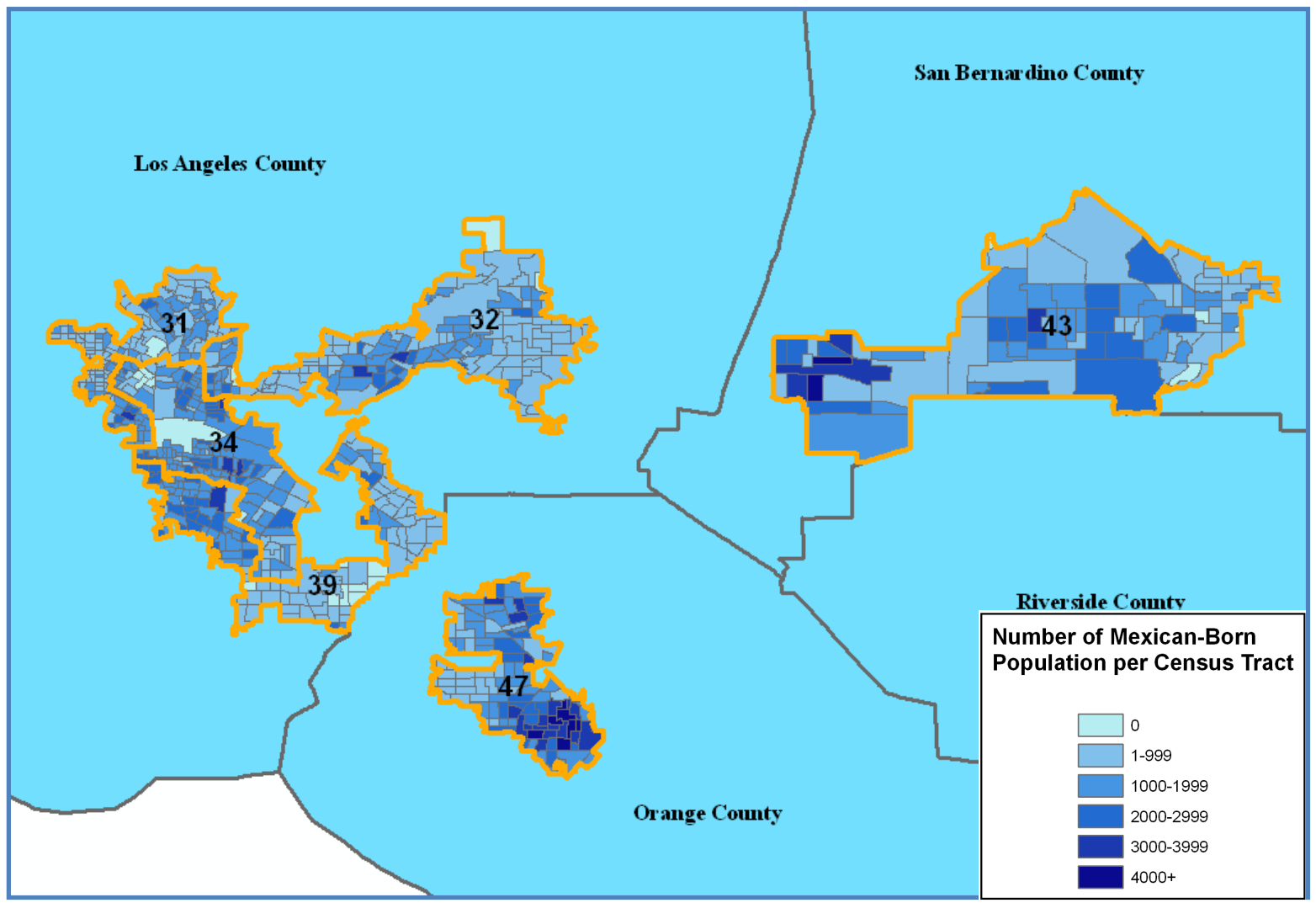

Source: U.S. Census Bureau, "Census 2000 Summary File 4" database. Online. Available: http://factfinder.census.gov. Accessed: March 4, 2010. 


\section{Notes}

${ }^{1}$ Kevin F. McCarthy, and R. Burciaga Valdez, Current and Future Effects of Mexican Immigration in California. (1986), pp. 5. Online. Available: http://www.rand.org/pubs/reports/2006/R3365.pdf. Accessed: May 1, 2010.

${ }^{2}$ Ibid., pp. 5-6.

${ }^{3}$ Ibid., p. 5.

${ }^{4}$ Ibid., p. 6.

${ }^{5}$ Ibid.

${ }^{6}$ Ibid., p. 7.

${ }^{7}$ Ibid., p. 8.

${ }^{8}$ Aaron Terrazas and Jeanne Batalova, "Frequently Requested Statistics on Immigrants and Immigration in the United States," Migration Policy Institute, Migration Information Source (2009) Online. Available: http://www.migrationinformation.org/USfocus/display.cfm?ID=747\#3. Accessed: April 29, 2010

${ }^{9}$ Thomas Benitez, "East LA Past and Present,” American Family: Journal of Dreams. Public Broadcasting Services, 2004.

${ }^{10}$ Miryam Hazan, Incorporating in the United States and Mexico: Mexican Immigrant Mobilization and Organization in Four American Cities (Ph.D Diss., The University of Texas at Austin, 2006), p. 225.

${ }^{11}$ U.S. Census Bureau, "2006-2008 American Community Survey 3-Year Estimates." Online. Available: http://factfinder.census.gov/. Accessed: May 3, 2010.

${ }^{12}$ Dowell Myers, John Pitkin, and Julie Park, California Demographic Futures: Projections to 2030, by Immigrant Generations, Nativity, and Time of Arrival in U.S (Population Dynamics Research Group, School of Policy, Planning and Development, University of Southern California, February 2005), p. x. Online. Available: http://www-rcf.usc.edu/ dowell/CDFFULLreport2005.pdf. Accessed: May 1, 2010.

${ }^{13}$ Ibid.

${ }^{14}$ Hazan, Incorporating in the United States and Mexico, p. 225.

${ }^{15}$ Ibid. 


\title{
Chapter 6. Healthcare Portability in Europe: European Union Policy and Individual Member State Bilateral Agreements
}

\author{
by Andrea Haughton and Timothy Mattison
}

\section{Introduction}

Global migration is increasing throughout the world. Currently, approximately 200 million people are living outside of their countries of birth. ${ }^{1}$ Traditional reasons for migration such as economic opportunity, wars, and discrimination have been augmented by family unification, retirement, and accelerated by growing globalization. By-products of this migration are discrimination and assimilation issues, language barriers, healthcare portability issues, pension agreements, and relocation issues.

Globally, healthcare portability presents significant logistical challenges and is highly debated. For immigrants who have worked or paid into a host country's healthcare system for the majority of their adult lives, choosing to return to their home countries can mean the loss of healthcare benefits or access to routine care.

This chapter focuses on healthcare portability issues as a by-product of circular migration and examines select policies addressing healthcare portability between several political entities including the European Union (EU) and various countries with large migrant populations.

\section{European Union Policy on Healthcare Portability}

Over the last 20 years the European Union has developed a system that protects EU citizens in health emergencies when they travel to another member state and most EU national programs cover emergencies outside the EU—albeit with some variation. Immigrants that are working in the EU (or are permanent residents) generally have access to care when residing, but lose coverage when they retire in their home countries.

When the European Union passed legislation on freedom of movement for labor in the 1970s, a need for cross-border healthcare coverage arose. The EU thus created E111 and E111B. E111 covered emergency care and E111B guaranteed hospitalization if needed to citizens traveling within the EU. The E111 was the most common form used. ${ }^{2}$ However, E111 forms (even after revisions) were confusing, and patients often did not know when to use them. Because of these complications, combined with a desire to modernize information-sharing and make reimbursement schemes more efficient, in the early 2000s the EU began planning for a conversion to a European Health Insurance Card (EHIC).

On June 18, 2003, the European Union passed Decision No 191 concerning the replacement of forms E111 and E111B by the European health insurance card. The decision laid out an order that would eventually replace the E111 with the EHIC. 
Accordingly, members of EU states were expected to use the EHIC to access healthcare during temporary stays in other member states. In addition, the commission suggested introducing the EHIC in three stages to mitigate the shock to the current E111 system. Finally, the commission ordered that the EHIC make a distinction between "necessary care" and "immediately necessary care." That same day the EEC passed Decision No. 189 aimed at introducing a European health insurance card to replace the forms necessary for the application of Council Regulations (EEC) No 1408/71 and (EEC) No 574/72 as regards access to health care during a temporary stay in a member state other than the competent state or the state of residence. In it the EEC formally define recipients of EHIC benefits as those who are eligible under (EEC) No. 1408/71, or those who incur "healthcare costs during a temporary stay in a Member State other than the competent state or, for recipients of a retirement or other pension and family members who do not reside in the Member State as the worker, in a Member State other than the state of residence." Furthermore, they required that the EHIC be identically formatted in all countries and specified what information was necessary to include on the card. The EEC invited, but did not require, countries to replace their national health insurance card with the EHIC.

The following year, the EEC passed Decision No. 197 in March 2004 on the transitional periods for the introduction of the European Health Insurance Card in accordance with Article 5 of Decision No. 191. Decision No. 197 outlines implementation for the EHIC (created in 2003 with Decision No. 191). The EEC ordered immediate conversion from E111 to the EHIC. However, it gave each country the opportunity to transition to the new system and nearly half of the EU opted for the transitional route. The last of these transitions ended in December 2005 and today all EU countries now use the EHIC. ${ }^{3}$ Once the transitions were complete, EEC concern over proper adherence to EHIC's emergency-care-only policy shifted to a focus on the policy's negative effect on patient access to care (EHIC would not cover non-emergency care while abroad).

In response to this issue, EEC members drafted a September 2008 directive that resulted in the release of recommendations in mid-2009. Once passed, the directive will entitle EU citizens (in member states other than their country of origin) to use the EHIC to seek emergency and non-emergency care abroad. The citizens' state of origin then reimburses the patient up to the benefit they would have received at home, leaving the balance as the patient's out-of-pocket responsibility. The most significant commission recommendations were that the directive should refrain from enforcing a common EHIC compensation practice. The commission suggested that the directive provide a framework for the right to cross-border healthcare. In addition, the commission suggested that member states be able to set their own definitions for hospital vs. nonhospital (emergency vs. non-emergency) care and those improvements be made on available information about each country's healthcare system. Finally, the commission recommended that patient records be digitized to increase efficiency in cross-border healthcare services and reimbursements. ${ }^{4}$

The directive is only a general framework for cross-border healthcare patient rights, which member states will implement to fit their national, regional, and local systems. 
And the EU has not implemented it yet. The commission sent the directive to both the European Parliament and the EU Council of Ministers for adoption. After they adopt the directive they will form a committee to specify further measures necessary for its implementation, such as a community level list of treatments which EU citizens can expect to receive. ${ }^{5}$

This directive will improve access to cross-border healthcare, which is not covered by current EHIC "emergency-care-only" policy in addition to increasing cross border demands. The latter effect instigates questions regarding member states' current ability to meet that demand. Retiree recipient countries already struggle to administer healthcare due to language barriers and opposing cultural expectations (of medical providers). ${ }^{6}$

\section{Britain and Spain's Portability Arrangement}

Retired Europeans have flocked to Spain since the 1970s for its beauty, climate, relatively low cost of living, and for purposes of family unification. ${ }^{7}$ A large portion of retirees immigrating to Spain are coming from the United Kingdom (UK), Germany, and France (this section focuses on British retirees). ${ }^{8}$ Demographers disagree on exactly how many British people reside in Spain for several reasons. Many Britons travel back and forth between the UK and Spain, spending only part of the year in each country. Additionally, many British people residing in Spain temporarily come and go too quickly to be counted in official census efforts or retirees relocate back to the UK without notifying Spanish authorities. Also, many Britons never register with the Spanish authorities rendering official numbers deflated estimates at best. ${ }^{9}$ The best estimate currently of the number of Britons living in Spain is 351,919. ${ }^{10}$ However, this source does not parse out the number of British retirees living there. The best source available to date to determine the number of official British retirees in Spain is the number of transferred pensions. As of 2006, the number of transferred pensions totaled 76,357. ${ }^{11}$ This of course does not count those who have retired to Spain under the radar as discussed above.

British retirees previously would have filed an E111 form to access healthcare abroad. ${ }^{12}$ The EEC replaced the E111 with the EHIC in 2005 when it fully implemented Decision No. 197, but the principle remains the same. The EHIC (similar to E111) is designed to provide temporary coverage to travelers abroad. British retirees in Spain, therefore, use the EHIC if they reside in the UK for more than six months of the year. If these retirees decide to reside permanently in Spain and (as often happens) receive benefits for longterm incapacity, severe disablement, and bereavement or from state pensions, then they need to file an E121 form to transfer their healthcare to the Spanish system. ${ }^{13}$ One compelling reason for transferring these benefits to the Spanish healthcare system is that people who receive these benefits often need continuous care, a situation for which the temporary-natured EHIC isn't designed. Then again, EHIC benefits do not include nursing home care, because it is the Spanish private sector that provides these services and at prices the UK is unwilling to pay. ${ }^{14}$ 
E121 forms can be obtained from the UK's Pension Service and are submitted to the local Spanish Sickness Insurance Office once completed. ${ }^{15}$ Persons who file the E121 form to transfer their rights are treated as Spanish citizens with full access to Spanish universal health insurance and the UK reimburses Spain for patient expenses. ${ }^{16}$ If pensioners want to transfer their healthcare back to the UK they simply need to inform the UK's International Pension Centre. ${ }^{17}$ It is yet unclear what effect the 2008 directive to allow cross-border non-emergency care will have on E121. Once the EU passes the directive, English citizens might decide to retain their British coverage to avoid the hassle transferring back to the UK health care system if they decide to return. Nevertheless, E121 is for the time being an important topic to discuss, because of the challenges that are present when transferring rights from the UK to Spain.

Challenges that arise for British citizens when they transfer their healthcare to Spain have been well documented. One issue is that once transferred to the Spanish healthcare system, British retirees must use state-run hospitals, which may not have parity with services offered at UK institutions. ${ }^{18}$ Additionally, even when Spanish hospitals do provide a particular service (e.g., hip replacement) the Spanish National Healthcare System doesn't provide after-care for people in their homes. Spanish families have traditionally provided this care. ${ }^{19}$ Another challenge is many British retirees in Spain inability to speak Spanish, affecting their ability to communicate with their providers. ${ }^{20}$ Challenges created by communication barriers are decreasing because hospitals, in hightraffic areas such as Costa de Sol, hire interpreters and encourage the use of private translators. ${ }^{21}$ Generally, being linguistically isolated is compounded by the remoteness of locations where some British pensioners retire. Social workers in Spain have found some elderly Britons in remote areas who apparently died alone. ${ }^{22}$

Reimbursements for service is a necessary component of transferring patients to alternate healthcare systems and, to this end, negotiations between Spain and the UK yielded a formula-driven, advance annual lump-sum payment to compensate for the projected number of British patients who will utilize the Spanish healthcare system. ${ }^{23}$ However, Spain does not use lump-sum payments to reimburse hospitals directly for services rendered. In a private healthcare system this direct reimbursement gives hospitals the incentive to track costs for services. Spain instead uses lump-sum payments as general revenues. Therefore, hospitals lack the incentive to keep detailed records of services and costs, and the system becomes inefficient. ${ }^{24}$ Then again, this inefficiency is improving in places like Costa Blanca (Valencia Region) where a new law terminated free healthcare for an estimated 500,000 Britons. Since 2002 Spain offered free healthcare to boost sales in its property market. In Costa Blanca proper reimbursement administration became necessary as the global financial crisis' negative effect on Spain's property market made providing free healthcare too costly for the region. ${ }^{25}$

The lump-sum payment system reimburses Spain for services that registered Britons receive. For instance, in 2007-2008 the UK paid out a total of \$550 million in lump-sum payments to various countries, and according to official reports Britons were given only $\$ 80$ million in healthcare-related services. During this period, the UK paid Spain $\$ 122$ million in lump-sum payments, while official reports indicate that British patients utilized 
approximately $\$ 14$ million in healthcare services. ${ }^{26}$ At first glance this lump-sum payment system seems inefficient and in need of changes that will make lump-sum payments match services rendered to Britons in Spain. The EEC seems to think so since it has already recommended a more sophisticated electronic patient service and fee record-keeping and reimbursement system in its draft directive comments explained in the previous section. However, the UK's lump-sum payment may match actual services better than meets the eye. Reported services (the $\$ 80$ million worth) doesn't include unregistered Britons in Spain who use Spanish services, which are not officially reimbursed by the British government. When these unregistered Britons are accounted for, the lump-sum payment to Spain may be just right.

\section{Germany and Spain's Portability Arrangement}

Germans are part of the population of retired Europeans who have flocked to Spain since the 1970s for its beauty, climate, relatively low cost of living, and for family unification. ${ }^{27}$ The number of Germans living in Spain as of 2008 totaled approximately $180,650 .^{28}$ German retirees in Spain are estimated to constitute 29 percent of all Germans living there ${ }^{29}$ German retirees in Spai,n like Britons, used to file an E111 form to access healthcare abroad. ${ }^{30}$ And while the EEC replaced the E111 with the European Health Insurance Card (EHIC) in 2005, coverage remains the same. The EHIC provides temporary coverage to travelers abroad. Again, the compelling reason for transferring these benefits to the Spanish healthcare system is that people who receive these benefits often need continuous care, a situation for which the EHIC isn't designed. Then again, EHIC benefits do not include nursing home care, because it is the Spanish private sector that provides these services and at prices the UK is unwilling to pay. ${ }^{31}$

Persons who file the E121 form to transfer their rights are treated as Spanish citizens with full access to Spanish universal health insurance and Germany reimburses Spain for patient expenses. ${ }^{32}$ Again, the 2008 directive to allow cross-border non-emergency care may change the E121 system. Once the EU passes the directive, like Britons, German citizens might decide to retain their German coverage to avoid the hassle transferring back to Germany if they decide to return. Nevertheless, E121 is an important topic to discuss because of the challenges that are present when transferring rights from the Germany to Spain.

Challenges that arise for German citizens when they transfer their healthcare to Spain are similar to those of British immigrants. Once transferred to the Spanish healthcare system German retirees use state-run hospitals, which may not offer as many services as in Germany. ${ }^{33}$ Additionally, even when Spanish hospitals do provide a particular service (e.g., hip replacement) the Spanish National Healthcare System doesn't provide after-care for people in their homes. Spanish families have traditionally provided this care. ${ }^{34}$ German retirees in Spain are also often unable to speak Spanish, making it difficult to communicate with providers. ${ }^{35}$

However, unlike Britain's National Health Service which does not bill at point of service, the German Health system is organized around a number of nonprofit insurance 
"trusts."36 Many of these insurance trusts have developed a relationship with not only Spanish public hospitals, but also private clinics and hospitals. Because of these relationships, Germans have fewer incentives to transfer their benefits to the Spanish public system. The major incentive to transfer benefits is to obtain routine care. The relationships between German trusts and Spanish clinics make this incentive moot. Germans can get routine care without transferring their benefits.

\section{Bilateral Portability Arrangements between Member and Non-Member States}

\section{Germany and Turkey}

Migration between Turkey and Germany has been well established since the early 1960s. At the time, West Germany had a labor shortage and invited the influx of Turkish immigrants to increase the labor supply in the short run. A bilateral agreement, concluded in 1961, between Turkey and West Germany established a short-term policy of Turkish workers under the "Gastarbeiter" (guest worker) program. However, by 1967 the immigrants' short-term intentions shifted to long-term habitation intentions. ${ }^{37}$ By 2006, migrant workers accounted for 6.8 percent of all employees liable to German social security contributions in 2006. In 2007, immigrants constituted 8.2 percent of Germany's total population $\left(6,744,879\right.$ persons). ${ }^{38}$ In 2008 , data shows that the German population had increased to 82.14 million persons, ${ }^{39}$ of whom approximately 1,688,370 million persons were Turkish citizens (approximately 25 percent of Germany's foreign population). ${ }^{40}$ The number of Turkish citizens residing in Germany is declining due to alterations in the laws governing citizenship (Turkish citizens have increasingly adopted German citizenship and policy changes in 2000 allowed children born to foreign parents in Germany to be German citizens, as opposed to the preceding policy of blood relations to establish citizenship). ${ }^{41}$ The most current data from October 2009 indicates that approximately 2.5 million people of Turkish descent are residing in Germany. Of this population, approximately 700,000 have adopted German citizenship ${ }^{42}$ (dual citizenship is not tolerated; if a child is able to have dual citizenship by way of his or her parents, citizenship of one country must be selected between the ages of 18 and 23). ${ }^{43}$

The primary reasons that Turks immigrate to Germany are the pursuit of higher wages, accumulation of assets, and family unification ${ }^{44}$ and there is some evidence of return migration to Turkey after living in Germany for a number of years. A 2002 study conducted by Oliver Kirchkamp and Christian Dustmann suggests, based on surveys conducted, that 43 percent of Turkish immigrants who return to Turkey are in retirement status once there, 51 percent of return immigrants operate small businesses, and 6 percent re-enter the Turkish workforce as salaried workers. ${ }^{45}$ The study also speculates that because the median age of Turkish retirees among workers was 45 years of age, certain immigrants had accumulated enough assets by a relatively early age to remain retired ${ }^{46}$ (though it is uncertain if the survey accounted for the allowances of the Turkish retirement system to continue working informally and receive social security pensions). 
Return immigrants are motivated to return to Turkey for a number of social, demographic, cultural, and economic reasons. The increase in purchasing power when living off of pensions when moving from Germany to Turkey is a large incentive to bring immigrants home. Furthermore, Turkish migrants accrue greater returns on physical and human capital in their home country. ${ }^{47}$ Historically, Turkish re-migration from Germany has experienced high peaks and dips given certain political and economic situations1983 was one such year. In 1983 the German government passed the Voluntary Repatriation Encouragement Act, which resulted in approximately 250,000 foreigners leaving Germany. ${ }^{48}$ Under this act, "families who had worked in Germany were only reimbursed what they had paid into the statutory retirement scheme over the years. Employers' contributions were not paid out and those returning home had to forsake all further claims. Moving back to Turkey was therefore a momentous decision." 49 It has been suggested, however, that while older generations of Turkish immigrants residing in Germany articulate intentions of returning to Turkey, many do not ever actualize this intention. There are arguments that it "can no longer be assumed that Turkish immigrants in Germany ultimately wish to return home. The future of the second and third generation will definitely take place in Germany."

In addition to the previously discussed German changes that have decreased the number of Turkish nationals obtaining German citizenship, Turkey has implemented policies for Turks migrating abroad which will likely further increase the number of Turkish immigrants remaining in Germany upon retirement. In 1995, Turkey made it easier for Turks abroad to naturalize into their host countries by creating a "special foreign nationality" symbolized by a pink card for Turks who give up their Turkish citizenship but want to preserve their right to buy and inherit land in Turkey. Also in 1995, Turks under age 20 were permitted to give up Turkish citizenship without fulfilling their Turkish military obligations. Then on February 16, 1998, the Turkish Government created two commissions to deal with migrant issues: a Supreme Committee for Nationals Living Abroad chaired by the Prime Minister and a Coordinating Committee for Nationals Living Abroad, which includes representatives of Turks in 12 foreign countries. $^{51}$

Numbers of Germans residing in Turkey are small but increasing. Currently, approximately 70,000 Germans reside in Turkey. ${ }^{52}$ This population is largely comprised of the following groups: Germans with Turkish spouses, German citizens employed in Turkey, German retirees, and tourists spending the majority of the calendar year in Turkey. ${ }^{53}$ Another major group is German managers who move to Turkey to work for German multinational companies. These companies - examples of which include Mercedes Benz, Bosch, and Volkswagon—relocate to Turkey because of the country's labor surplus and lower production and operation costs. ${ }^{54}$

Both Turkish return immigrants and retired German nationals are eligible for German pension benefits if they meet certain criteria. For German nationals to access pensions, workers must meet a qualifying period that can be five, 15, or 35 years depending on the type of pension to which they have been contributing. To meet the five or 15 year qualifying period workers must have made compulsory or voluntary pension 
contributions. If they did not make these contributions, they can still meet the qualifying period if political persecution kept them from making these contributions, or if pension rights and the minimum threshold for contributions changed. ${ }^{55}$ However, to meet the 35year qualifying period workers get credit for legally approved non-income periods (for example the time spent raising a child). Officials include these periods into their pension calculation. Other legally approved non-income periods include times of illness, pregnancy, and unemployment, or if the worker sought an education. ${ }^{56}$ German nationals employed or self-employed overseas are bound by the social security laws of the state in which they are employed. ${ }^{57} \mathrm{G}$ erman nationals and nationals of EU member states residing "outside the member states will receive their pension in full only from periods of insurance in the current territory of the Federal Republic of Germany" and bilateral agreements (such as the agreement between Turkey and Germany) allow Turkish citizens to be treated on par with German nationals as long as the pensioner resides in either Germany or Turkey. ${ }^{58}$

After healthcare reforms in 2007, health insurance in Germany became mandatory for every person residing in Germany (in keeping with this law, all German workers are required to have health insurance irrespective of nationality). Health insurance must be obtained through private or public options unless otherwise covered. Most Germans (approximately 72 million persons) are insured by the statutory health insuranceGesetzliche Krankenversicherung (referred to as GKV). ${ }^{59}$ GKV benefits include inpatient care at a hospital nearest to the physical location of the patient; out-patient care with network doctors; basic dental care; maternity care health check-ups; medical appliances; preventative care/examinations for cancer, heart circulation, kidney diseases and diabetes; some home care; prescriptions; and other benefits. ${ }^{60}$ The insurance covers non-working dependents listed at the patient's address. ${ }^{61}$ An additional 8.5 million persons are insured via private schemes. The healthcare reforms evidently will include the introduction of "an inexpensive basic tariff and the portability of old age reserves",62 which have thus far been elusive. Both public and privately insured persons now automatically pay into a government long-term nursing care scheme. Generally, employers pay approximately half of both health insurance contributions (regardless of public or private) and long-term nursing care contributions; the employee is responsible for the remaining half. Once the worker retires, the pension funds contribute the employer's portion of the contributions to the sickness and long-term nursing care funds and the pensionser pays the portion according to the respective contribution rate of the sickness fund. ${ }^{63}$

Limited healthcare services for return Turkish immigrants and German pensioners retiring in Turkey are covered under the bilateral agreement between the two countries. ${ }^{64}$ The agreement applies to German nationals, Turkish nationals, refugees under the Geneva Convention, stateless nationals of third countries and any German employee in Germany who is governed by the German legislation regardless of nationality. German pensioners residing in Turkey are entitled to receive "any medical treatment in kind that cannot be expected to be delayed until the pensioner returns to Germany."65 A worker in Germany who chooses to move to Turkey before retirement age may voluntarily contribute to German pension schemes to continue receiving healthcare under the 
German schemes. The agreement also has a provision to ensure emergency care in medically necessary cases for temporary stays in Turkey (and vice-versa), but "in cases where serious medical treatment is necessary-heart surgery, for example - the migrant has to return to the country where she is insured." 66 This particular provision is partially aimed at avoiding large expenses on behalf of the Turkish health system in the event that a person covered under the Turkish health insurance falls ill in Germany. Under the agreement, reimbursements are required to be paid to the health system of the country providing the services and as treatment costs are much higher in Germany than Turkey, reimbursements could become unmanageable (on the part of the Turkish Health system). ${ }^{67}$

Generally, a pensioner has options with regard to the compulsory health insurance schemes. These options include making voluntary contributions to the state schemes or making voluntary contributions to private insurers. German pensioners (residents) are "compulsorily insured under the German health insurance scheme for pensioners if you have paid (compulsory) contributions to the German state health insurance scheme for a certain time." ${ }^{68}$ Payments to other countries' health insurance funds are not taken into account with regard to the qualified insurance periods. If liable for compulsory health insurance contributions, the pensioner would also be required to be insured under the German state nursing care insurance scheme. These compulsory payments are withheld from a pensioner's payments and contributed to the compulsory schemes. ${ }^{69}$ If a pensioner is not liable for contributions to state health insurance schemes then that pensioner may apply for allowances to go towards health and nursing care insurance contingent upon making voluntary contributions to "the German state health insurance scheme or a member for a private health insurance carrier which is subject to supervision by Germany or a Member State of the European Economic Area."70 (According to "Working in Israel" residents of countries other than Germany will not be able to be compulsory insured under the German health and nursing care insurance scheme and are no longer covered under the schemes upon relocation from Germany. However, a pensioner who moves from an outside country to Germany can potentially qualify by fulfilling necessary requirements to pay into the healthcare schemes. ${ }^{71}$ )

The underlying principle is that the migrant is always covered by the public health insurance of the country of residence. Hence, a Turkish migrant who moves to Germany for work is covered by the German public health system. Once she moves back to Turkey, she will be covered by the Turkish system, if she is employed in Turkey or receives a pension from the Turkish pension system. The only exception is a migrant who receives a pension from only one of the two countries, but lives in the other one, in that case the pensioner has full access to all public health benefits in kind in the country of residence, at the expense of the health insurance of the country from which she receives her pension. The expenses are transferred on a case-by-case basis, so that the country of residence is reimbursed for the actual health costs of the pensioner, or the institution that pays the pension transfers monthly payments based on the average health costs of pensioner in the country of residence. ${ }^{72}$ 
Unlike their German counterparts, Turkish residents in Germany are not entitled to longterm care benefits (or nursing schemes) as it is neither a part of their pension contribution nor a subsidy granted by the German government. German nationals are covered for all of their long-term healthcare needs via direct deduction. Essentially, Turkish citizens forfeit their right to long-term healthcare under the German pension system if they become permanent residents of Turkey. For German citizens, this rule is mildly flexible for temporary moves, e.g., a pensioner is gone for a period of a maximum six months (or longer with permission of the immigration offices). These German migrants can apply for benefits from the long-term nursing care industry upon return home.

German bilateral agreements were efforts to curb guest worker programs that resulted in large percentages of migrant workers settling permanently in Germany, therefore putting a strain on the German social insurance systems. Germany currently admits seasonal workers (approximately 330,000). Seasonal workers are limited to 90 days of employment in Germany per work year (though it is possible to obtain multiple contracts per work year). "Since many of these workers are employed in the origin county, most are already covered under their national social insurance system," meaning that Germany's employees will experience cost savings from not paying into the mandatory social insurance schemes for these seasonal workers. ${ }^{73}$

A factor to keep in mind is that in Germany "portability of coverage, eligibility, and benefits are independent of any regional and/or local reinterpretations by either insurers, politicians, administrators, or healthcare providers. Universal coverage is honored by any medical office or hospital. Check-ins at doctors' offices, hospitals, and specialized facilities are simple, and individuals receive immediate medical attention." ${ }^{.74}$ This essentially means that persons in need of care cannot be turned away without risking violations of medical ethics codes and/or Germany's hospital laws. ${ }^{75}$

A constraint on low-income retirees from Germany retiring to both Turkey and Spain is that while their pension and health coverage is portable the "top up" additional support payments received from the German government are not.

\section{Austria and Turkey}

Austria and Turkey have concluded a bilateral agreement governing healthcare benefits for pensioners moving between countries. Under this agreement, Turkish immigrants working in Austria (who have not been employed in Turkey) receive an Austrian pension when they return home for retirement and remain covered by the Austrian healthcare for emergency and non-emergency care. Similarly, Austrian pensioners retiring in Turkey are also able to transfer their benefits. Austrian retirees are treated the same as Turkish retirees, even paying the same deductibles and /or fees. Additional costs are reimbursed by Austria via direct transfer as determined on a case-by-case basis. ${ }^{76}$ All benefits are inkind for network healthcare providers. Patients residing in Turkey, who choose to receive medical services from out-of-network providers (i.e. a provider who is not part of the Turkish social health insurance system) can submit a claim to the Austrian social heath insurance system to receive a reimbursement. This reimbursement covers 80 percent of the in-network costs of the services provided (generally this is very low). ${ }^{77}$ 
Under the agreement between Austria and Turkey, there are two categories of retirees. The first (i) category consists of pensioners who receive a public pension in both countries (Austria and Turkey). The second (ii) category consists of persons who receive a public pension in only one country. For pensioners under category (i), the social health insurance of the country of residence (i.e., Turkey if the retiree resides in Turkey) covers all health costs even in the event that the pensioner returns to Austria for short periods of time. ${ }^{78}$ There is no requirement for travel back and forth as eligibility hinges only upon receiving a public pension in both countries. For pensioners under category (ii), the social health insurance of Austria will cover all health costs for the retiree while he lives in Turkey (true for short-term stays and long-term stays). The retiree remains under the coverage of the Austrian social health insurance, but has full access to the Turkish social health insurance provider network to obtain in-kind services at no cost (though a pensioner would be subject to Turkish co-payments). The Austrian social health insurance system then directly reimburses the Turkish social health insurance system. ${ }^{79}$

The Austria-Turkish agreement also prevents medical tourism by allowing temporary visitors to have access to stabilizing emergency care, but requiring that they be removed to their country of residence for most procedures such as heart surgery, brain surgery, and hip replacement. ${ }^{80}$

\section{Spain and Morocco}

Moroccans have been migrating to Spain in small numbers since the Spanish and French colonial periods. The 1960s and 1970s witnessed significant increases in immigrants relocating from Morocco to Spain before the en masse migration a decade later. Prior to this large-scale influx of immigrants, Spain's economy was shambles after the economic and political isolation under the Franco regime. This regime also saw a large exportation of migrants (Spain was sending more migrants abroad than it was receiving). The catalyst for this new influx of migration came in the 1980s with the International Monetary Fund. This policy fostered economic growth in Spain, in addition to transforming Spain into a land of opportunity for Moroccan immigrants. The potential for larger incomes coupled with Morocco's close proximity to Spain, an increase in Spanish labor-scarcity from a declining birth-rate, a desire to reunite with earlier migrant relatives, and weak visa laws (until 1991) caused massive Moroccan migration. ${ }^{81}$ By the end of March 2007, Spanish authorities had 575,460 Moroccan migrants on record as resident permit holders. However, this estimate does not include second-generation Moroccan immigrants who became naturalized in Spain or undocumented immigrants, ergo, the total number of Moroccans in Spain could be up to 50 percent above the estimate. $^{82}$

As Moroccan immigration to Spain increased, migrants in the workforce began demanding social security benefits and the ability to retain their benefits upon relocation in Morocco for retirement. Lack of portability can be speculated to be the reason that return migration (between Morocco and Spain) has decreased significantly after several decades (tens of thousands still do return to Morocco). ${ }^{83}$ In response, Spain passed a Social Security Agreement with Morocco on November 8, 1979, which came into force 
on October 1, 1982. The agreement mandates that pensioners are guaranteed health care coverage from the pension-granting country. If pensioners do not meet the pension contribution requirement, Spanish authorities add years worked in Morocco and Spain together provided that the time periods of employment are not overlapping. However, to be able to transfer their healthcare to Morocco, pensioners must have family residing there. Once transferred, the Moroccan healthcare system is the main provider of care for the patients (and all care is subject to the country's regulations). ${ }^{84}$

Minimal studies have been conducted to provide insight into understanding the challenges Moroccans face when they return to Morocco and transfer their health care though some information regarding challenges has been published. Interviews with major healthcare providers found several major flaws in the Moroccan system, which would affect return migrants. First and foremost, Morocco spends too little to provide "universal healthcare." Second, the rural poor have unequal access to health care facilities. Third, health care in Morocco is poorly regulated, increasing the likelihood of abuse and related complications. Finally, the Moroccan system is overburdened by several unusually prevalent health problems including digestive and parasitic diseases and tuberculosis. ${ }^{85}$ All of these problems coalesce and complicate immigrant healthcare transfers between Spain and Morocco.

While healthcare benefits of immigrants moving between Spain and Morocco are currently governed under the aforementioned bilateral agreement, the near future might hold statutory changes that render the agreement moot. In 2000, the EU signed a bilateral agreement with Morocco called the Mediterranean Agreement. Article 65 of this agreement requires member states to allow Moroccan migrants to transfer their pensions to Morocco upon retirement. ${ }^{86}$ Prior to this each member state to which Moroccans migrated signed their own pension portability agreement. The Mediterranean Agreement also required member states to work with Morocco to improve social conditions (including healthcare) for Moroccan immigrants. ${ }^{87}$ And as discussed earlier in this paper, the $\mathrm{EU}$ is close to finalizing a directive mandating unlimited healthcare portability for those using the EHIC. Perhaps healthcare portability for Moroccan migrants is the logical next step.

\section{Conclusion}

Global and circular migrations are increasing and more countries are finding themselves formulating programs to ensure that their citizens are able to receive adequate health care when they are abroad. The overview of different systems spanning provides a background for researchers in the United States who are evaluating the best practices for portability of healthcare benefits. 


\section{Notes}

${ }^{1}$ World Bank, World Bank Migration and Remittances Fact Book 2008. Online. Available: http://econ.worldbank.org/WBSITE/EXTERNAL/EXTDEC/EXTDECPROSPECTS/0,,contentMDK:2135 2016 menuPK:5963318 pagePK:64165401 piPK:64165026 theSitePK:476883 isCURL:Y,00.html. Accessed: May 5, 2010.

${ }^{2}$ Easy Expat, Frequently Asked Questions. Online. Available: http://www.easyexpat.com/en/faq/ health/q34.htm. Accessed: February 8, 2010.

${ }^{3}$ EUR-Lex, The EU's portal to EU law. Online. Available: http://eur-lex.europa.eu/en/index.htm. Accessed: September 15, 2009.

${ }^{4}$ Opinion of the European Economic and Social Committee on the "Proposal for a Directive of the European Parliament and of the Council on the application of patient rights in cross-border healthcare." Official Journal of the European Union, vol. C175, no. 22, July 28, 2009, p. 1. Online. Available: http://eur-lex.europa.eu/en/index.htm. Accessed: February 8, 2010.

${ }^{5}$ Europa, Gateway to the European Union. Online. Available: http://europa.eu/rapid/pressReleases Action. do?reference $=$ MEMO/08/473\&type $=$ HTML\&aged $=0 \&$ language $=e n \&$ guiLanguage $=e n$. Accessed: February 8, 2010.

${ }^{6}$ Magdalene Rosenmoller and Maria Lluch, "Meeting the needs of long-term residents in Spain," in Patient Mobility in the European Union: Learning from Experience, ed. Magdalene Rosenmoller, Martin McKee and Rita Baeten (Geneva, Switzerland: World Health Organization European Observatory on Health Systems and Policies, 2007), p. 65.

${ }^{7}$ Vincente Rodriguez, Gloria Fernandez-Mayoralas, and Fermina Rojo, "European Retirees on the Costa del Sol: A Cross-National Comparison," International Journal of Population and Geography, vol. 4 (1998), p. 184. Online. Available: http://www.googlescholar.com. Accessed: February 29, 2010.

${ }^{8}$ Rosenmoller and Lluch, "Meeting the needs of long-term residents in Spain," p. 61.

${ }^{9}$ Irene Hardill, Jacqui Spradbery, Judy Arnold-Boakes and Maria Luisa Marrugat, "Severe health and social care issues among British migrants who retire in Spain," Ageing and Society (2005), vol. 25, p. 770. Online. Available: http://www.googlescholar.com. Accessed: February 29, 2010.

${ }^{10}$ Instituto Nacional de Estadística, Evolution of the foreign population in Spain since 1998. Online. Available: http://www.ine.es/. Accessed: March 12, 2010.

${ }^{11}$ Helena Legido-Quigley and Daniel La Parra, "The health care needs of UK pensioners living in Spain: an agenda for research," Eurohealth, vol. 13, no. 4, p. 15. Online. Available: http://googlescholar.com.

Accessed: March 10, 2010.

${ }^{12}$ Rosenmoller and Lluch, "Meeting the needs of long-term residents in Spain," p. 63. 
${ }^{13}$ Britain's Department of Work and Pensions' (DWP), International. Online. Available: http://www.dwp.gov.uk/international/medical-services/healthcare-arrangements-for-people/getting-longterm-incapacity-benefit/. Accessed: January 25, 2010.

${ }^{14}$ Ibid.

${ }^{15}$ Ibid.

${ }^{16}$ Rosenmoller and Lluch, "Meeting the needs of long-term residents in Spain," p. 64.

${ }^{17}$ The Observer, England, News: How to Claim Your Rights, June 22, 2008. Online. Available: http://ukinspain.fco.gov.uk/en/help-for-british-nationals/pensions benefits/healthcare/. Accessed: September 22, 2009.

${ }^{18}$ Rosenmoller and Lluch, "Meeting the needs of long-term residents in Spain," p. 65.

${ }^{19}$ Hardill, Spradbery, Arnold-Boakes and Marrugat, "Severe health and social care issues among British migrants who retire in Spain," p. 772.

${ }^{20}$ Rosenmoller and Lluch, "Meeting the needs of long-term residents in Spain," p. 65.

${ }^{21}$ Andreas Huber and Karen O'Reilly, "The construction of Heimat under conditions of individualized modernity: Swiss and British elderly migrants in Spain,” Ageing and Society, vol. 24 (2004), pp. 336-337. Online. Available: http://www.googlescholar.com. Accessed: March 10, 2010.

${ }^{22}$ Hardill, Spradbery, Arnold-Boakes and Marrugat, "Severe health and social care issues among British migrants who retire in Spain,” p. 776.

${ }^{23}$ Rosenmoller and Lluch, "Meeting the needs of long-term residents in Spain," p. 65.

${ }^{24}$ Ibid., p. 67.

${ }^{25}$ Jacqueline Stevens, "News: Spain: Costa Blanca Britons to lose free healthcare: Valencia Region can no longer afford expats' bills as housing markets slide," The Observer, England, June 22, 2008, p. 17. Online. Available: http://www.lexusnexus.com. Accessed: September 28, 2009.

${ }^{26}$ United Kingdom Parliament, 2007-08 Resource Accounting and Budgeting (RAB) Exercise. Online. Available: http://www.parliament.uk. Accessed September 28, 2009.

${ }^{27}$ Rodriguez, Fernandez-Mayoralas and Rojo, "European Retirees on the Costa del Sol: A Cross-National Comparison," p. 184.

${ }^{28}$ Instituto Nacional de Estadística, Evolution of the foreign population in Spain since 1998 (online)

${ }^{29}$ Rosenmoller and Lluch, "Meeting the needs of long-term residents in Spain," p. 61. 
${ }^{30}$ Ibid., p. 63.

${ }^{31}$ Britain's Department of Work and Pensions' (DWP), International (online).

${ }^{32}$ Rosenmoller and Lluch, "Meeting the needs of long-term residents in Spain," p. 64.

${ }^{33}$ Ibid., p. 65.

${ }^{34}$ Hardill, Spradbery, Arnold-Boakes and Marrugat, "Severe health and social care issues among British migrants who retire in Spain," p. 772.

${ }^{35}$ Rosenmoller and Lluch, "Meeting the needs of long-term residents in Spain," p. 65.

${ }^{36}$ Ellen Kuhlmann and Judith Allsop, "Professional self-regulation in a changing architecture of governance: comparing health policy in the UK and Germany," Policy and politics, vol. 36, no. 2 (2008), p. 176. Online. Available: http://www.googlescholar.com. Accessed: March 12, 2010.

${ }^{37}$ Parliamentary Assembly, The situation of Turkish Migrant Workers in Europe. Online. Available: http://assembly.coe.int/Documents/WorkingDocs/doc04/edoc10358.htm. Accessed: November 25, 2004.

${ }^{38}$ European Working Conditions Observatory, Germany: The Occupational Promotion of migrant workers. Online. Available: http://www.eurofound.europa.eu/ewco/studies/tn0807038s/de0807039q.htm. Accessed: April 2, 2010.

${ }^{39}$ World Bank, Germany Data 2008. Online. Available: http://web.worldbank.org/WBSITE/EXTERNAL/ DATASTATISTICS/0,,contentMDK:20535285 menuPK:1192694 pagePK:64133150 piPK:64133175 th eSitePK:239419,00.html. Accessed: January 12, 2010.

${ }^{40}$ Statistisches Bundesamt, Statistical Yearbook 2009 For the Federal Republic of Germany. Online. Available: http://www.destatis.de/. Accessed: April 2, 2010.

${ }^{41}$ Observatory of European Foreign Policy, Turkish Migrants in Germany, Prospect of Integration. Online. Available: http://www.googlescholar.com. Accessed: March 2, 2010.

${ }^{42}$ German Federal Foreign Office, Turkey. Online. Available: http://www.auswaertiges-amt.de/diplo/en/ Laenderinformationen/01-Laender/Tuerkei.html. Accessed: January 30, 2010.

${ }^{43}$ Ed. Haldun Gülalp, Citizenship and Ethnic Conflict: Challenging the Nation-State (New York: Taylor \& Francis, 2006), p. 30.

${ }^{44}$ United Nations Department of Economic and Social Affairs Population Division Secretariat, International Symposium of International Migration and Development. Online. Available: http://www0.un.org/esa/population/migration/turin/Symposium_Turin_files/P06_Klinthall.pdf. Accessed: April 15, 2010. 
${ }^{45}$ Mrurat G. Kirdar, "Determinants of Return Migration of Turkish Immigrants in Germany," Department of Economics, Middle East Technical University, April 15, 2005. Online. Available:

http://www.googlescholar.com. Accessed: April 20, 2010.

${ }^{46}$ Ibid.

${ }^{47}$ Ibid.

${ }^{48}$ Sen Faruk, “Turkish Diaspora in Germany - Dialogue with the Islamic World.” Online. Available: http://www.qantara.de/webcom/show_article.php/_c-478/_nr-171/i.html. Accessed October 27, 2010.

${ }^{49}$ Ibid.

${ }^{50}$ Ibid.

${ }^{51}$ Elizabeth Midgley Martin and Michael Teitelbaum, "Report of the seminar on Migration and Development: Focus on Turkey," Center for Migration Studies of New York IMR, vol. 35, no. 2, pp. 596605. Online. Available: http://www.googlescholar.com. Accessed: April 2, 2010.

${ }^{52}$ German Federal Foreign Office, Turkey. Online. Available: http://www.auswaertigesamt.de/diplo/en/Laenderinformationen/01-Laender/Tuerkei.html. Accessed: January 30, 2010.

${ }^{53}$ Turk of America, The Germans in Turkey, Monday, October 15, 2007. Online. Available: http://www.turkofamerica.com/index.php?Itemid=174\&id=177\&option=com_content\&task=view. Accessed: October 5, 2009.

${ }^{54}$ Ibid.

${ }^{55}$ Bavarian Social Insurance Association, Deutsche Rentenversisherung. Online. Available: http://www.deutsche-rentenversicherung.de. Accessed: April 20, 2010.

${ }^{56}$ Ibid.

${ }^{57}$ Ibid.

${ }^{58}$ Ibid.

${ }^{59}$ German Ministry of Federal Health (Bundesministerium fur Gesundheit), Health Care System and Health Care Reform in Germany, April 15, 2009. Online. Available: http://www.bmg.bund.de/cln_178/ nn_1169696/EN/Gesundheit/gesundheit_node.html?_nnn=true. Accessed: January 12, 2010.

${ }^{60}$ Photius, Germany Development of the Health Care System. Online. Available: http://www.photius.com/countries/germany/society/germany_society_development_of_the_h 1372.html. Accessed: October 23, 2009. 
${ }^{61}$ UK Health Insurance Centre. Online. Available: http://www.privatehealth.co.uk/healthinsurance/ expatriate-health-insurance/by-country/\#Germany. Accessed: April 15, 2010.

${ }^{62}$ German Ministry of Federal Health (Bundesministerium fur Gesundheit), Health Care System and Health Care Reform in Germany (online).

${ }^{63}$ Deutsche Rentenversicherung Bund, Working in Germany and Israel. Online. Available: http://www.deutsche-rentenversicherung-bund.de/nn_96726/SharedDocs/en/Navigation/05

Formulare_Publikationen/02_Broschueren_node.html_nnn=true. Accessed: December 20, 2009.

${ }^{64}$ Robert Holzmann, Johannes Koettl, and Taras Chernetsky, "Portability Regimes of Pension and Health Care Benefits for International Migrants: An Analysis of Issues and Good Practices," The World Bank Social Protection Human Development Network, p. 24. Online. Available: http://www.gcim.org/ attachements/TP2.pdf. Accessed: April 2, 2010.

${ }^{65}$ Ibid., p. 25.

${ }^{66}$ Ibid., p. 25.

${ }^{67}$ Ibid., p. 26.

${ }^{68}$ Deutsche Rentenversicherung Bund, Working in Israel, December 1, 2007 (online).

${ }^{69}$ Ibid.

${ }^{70}$ Ibid.

${ }^{71}$ Ibid.

${ }^{72}$ Holzmann, Koettl, and Chernetsky, "Portability Regimes of Pension and Health Care Benefits for International Migrants: An Analysis of Issues and Good Practices," p. 26.

${ }^{73}$ Kathleen Newland, Dovelyn Rannveig Agunias, and Aaron Terrazas, "Learning by Doing: Experiences of Circular Migration," Migration Policy Institute. Online. Available: http://www.migrationpolicy.org/ research/migration_development.php. Accessed: March 10, 2010.

${ }^{74}$ Photius, Germany Development of the Health Care System. Online. Available: http://www.photius.com/ countries/germany/society/germany_society_development_of_the_h 1372.html. Accessed: October 23, 2009.

${ }^{75}$ Ibid.

${ }^{76}$ Holzmann, Koettl, and Chernetsky, "Portability Regimes of Pension and Health Care Benefits for International Migrants: An Analysis of Issues and Good Practices,” p. 27. 
${ }^{77}$ Email from Johannes Koettl, World Bank Consultant, "German Healthcare Portability to Turkey," to Andrea Haughton, November 3, 2009.

${ }^{78}$ Ibid.

${ }^{79}$ Ibid.

${ }^{80}$ Holzmann, Koettl, and Chernetsky, "Portability Regimes of Pension and Health Care Benefits for International Migrants: An Analysis of Issues and Good Practices,” p. 27.

${ }^{81}$ Hein De Haas, "Morocco's migration transition: Trends, determinant and future scenarios," Migration and Development Revisited (MDR) Working Paper No. 3, A WOTRO/NOW research project, March 2005, pp. 9-13. Online. Available: http://www.googlescholar.com. Accessed: February 7, 2010.

${ }^{82}$ United Nations Instraw, Moroccan Migration to Spain. Online. Available: http://www.un-instraw.org/ index.php?option=com_content\&id=345\&lang=en\&task=view\&Itemid=449. Accessed: February 7, 2010.

${ }^{83}$ Hein De Haas, "Morocco's migration transition: Trends, determinant and future scenarios," pp. 11-12.

${ }^{84}$ Government of Spain, Ministerio De Trabajo E Imigracion, Morocco. Online. Available: http://www.segsocial.es/Internet_6/Internacional/Conveniosbilaterales/Marruecos2k9/index.htm. Accessed: February 8, 2010.

${ }^{85}$ Achy Lahcen, "Assessing trade in health services in Morocco," Trade and Health, Compilation of Presentations made at the Inter-regional Workshop, p. 5. Online. Available: http://www.googlescholar.com. Accessed: February 8, 2010.

${ }^{86}$ Euro-Lex, Official Journal of the European Communities, EURO-Mediterranean Agreement establishing an association between the European Communities and their Members States, of one part, and the Kingdom of Morocco, the other part, March 18, 2000, Article 65. Online. Available: http://eur-lex.europa.eu/en/ index.htm. Accessed: September 15, 2009.

${ }^{87}$ Ibid. 


\title{
Chapter 7. Health Care in Canada
}

\author{
by Jennifer Schmalz
}

\section{Basics}

Despite the "universal" nature of the Canadian health care system, no one system exists. Instead, the current system is composed of 13 single-payer systems of hospital and physician care, called Medicare. Each of the ten provinces and three territories administer the health care system for their residents. The 13 systems vary considerably in terms of financing, administration, delivery modes, and range of public health services (see Table 7.1). ${ }^{1}$ There are three levels to the Canadian health care structure:

- Federal level, responsible for the standards for the national Medicare system, drug and food safety regulations, data collection and health research, and providing direct health care for First Nations, Inuit, armed forces, veterans, and Royal Canadian Mounted Police.

- Provincial/Territorial level, responsible for governing administration of the single-payer system for their residents, funding hospitals and prescription drug plans, and setting the physician remuneration rate.

- Intergovernmental level, responsible for the facilitation and coordination of policy and program areas.

The system evolved following the World War II. The Canada Health Act provides the framework for the health care system in Canada. ${ }^{23}$ Additionally, the Canada Health Act of 1984 set the following five conditions that provinces must meet for shared-cost funding through federal transfers:

- Universality

- Public administration.

- Comprehensiveness.

- Portability.

- Accessibility.

The total expenditure for health care in Canada was approximately 10.1 percent of the GDP in 2007. ${ }^{4}$ The federal government transfers the funds for health care to the provinces and territories on a per capita basis. Financing for health care primarily comes from taxation by the provincial, territorial, and federal governments. Taxation provides 70 percent of health care expenditures. The remaining 30 percent is privately funded by out-of-pocket payments and private health insurance. ${ }^{5}$ 


\section{Health Insurance}

The Canada Health Act provides health insurance for all Canadian citizens, permanent residents and those in Canada on a study or work permit (foreign visitors are excluded). Insured services, including hospital, physician, and diagnostic services, are provided at no cost at the point of delivery. Most dental care, vision care, long-term care, home care and pharmaceuticals prescribed outside of a hospital are excluded from insured services. Insurance for dental care and vision care is usually employment-based and treated as part of the compensation package. This private insurance is complementary to the public health care scheme, and designed to cover health services and goods not covered by the public system. ${ }^{6}$

All residents pay premiums (outright or in the form of taxes) for a government-run insurance plan and the public plan pays private doctors and hospitals according to a set fee schedule. For people who are employed, the employer will arrange health coverage and deduct the premium from the employee's salary. Otherwise, an individual applies and pays through the provincial health agency. ${ }^{7}$ Claims for out-of-country services are paid for at the point of service and reimbursed by the provincial health service.

\section{Residency}

The basic requirement for insured health care coverage is residence in a Canadian province/territory. Residence is maintained as long as the resident is in Canada for 183 days of the year (these requirements vary by province). Without residency, Canadians may receive health care from a pension plan or buy private insurance. When an individual moves from one province/territory to another, the home province covers health care for a 90-day waiting period. ${ }^{8}$

Portability requires that the province/territory extends medically necessary hospital and physician coverage to eligible residents during temporary absences from the province/territory. Prior approval is required for out-of-province/out-of-country health care when the absence is for the express reason of receiving medical treatment. Portability between provinces is achieved through bilateral reciprocal billing agreements, with the health care services covered according to the rate of the host province. ${ }^{9}$

The portability criterion does not allow individuals to seek services in another country. However, portability does allow individuals to receive necessary emergency services during temporary absences from Canada. In this situation, the province/territory may or may not pay the full amount billed for services performed. ${ }^{10}$

Additionally, Quebec provides portable health insurance to residents who move to Denmark, Finland, France, Greece, Luxembourg, Norway, Portugal, and Sweden according to social security agreements signed between these countries and the government of Quebec. Under these agreements, residents of Quebec who spend time in one of these countries may be covered by the country's health plan. Quebec reciprocates 
by covering residents of the signatory countries. The agreements apply to temporary workers, students, and workers detached from their employer. ${ }^{11}$

\section{American Retirees in Canada}

American retirees can enter Canada as a visitor for up to 183 days in any 12 month period. Unlike the Canadian Medicare system, which covers approved or emergency procedures performed outside of the province/territory of residency, American Medicare does not cover American living outside the U.S.

However, it is not easy for foreigners to retire in Canada, as no directly relevant immigrant class exists. Foreign-born retirees would be eligible only if they meet the requirements for family reunification or investor class. The investor class requires $\$ 400,000 \mathrm{CDN}$ to invest in an existing Canadian business.

\section{Table 7.1 Canadian Provincial Health Care}

\begin{tabular}{|c|c|c|c|c|}
\hline Province & Coverage & Period/Extension & Medicine & Reimbursement \\
\hline Ontario & $\begin{array}{l}\text { Services rendered by eligible } \\
\text { out-of-country hospitals and } \\
\text { health-care facilities for } \\
\text { medically necessary } \\
\text { emergency in-patient and } \\
\text { out-patient services. } \\
\text { Additionally, emergency } \\
\text { services for the purpose of an } \\
\text { acute, unexpected condition, } \\
\text { illness, disease or injury. } \\
\text { Ambulance service outside of } \\
\text { the province of Ontario is not } \\
\text { covered }\end{array}$ & $\begin{array}{l}\text { Short absences: max } 212 \\
\text { days every } 12 \text { months. } \\
\text { Also } 2 \text { years once in a } \\
\text { lifetime, for whatever } \\
\text { reason with prior } \\
\text { authorization. Absences } \\
\text { longer than } 212 \text { days for } \\
\text { students, work and } \\
\text { missionaries }\end{array}$ & N/A & $\begin{array}{l}\text { Based on pre-established } \\
\text { rates by the Ontario's } \\
\text { Ministry of Health. The } \\
\text { Ministry will pay the full } \\
\text { cost of reimbursement } \\
\text { for procedures that are } \\
\text { granted prior approval, } \\
\text { treatment not available } \\
\text { in Ontario, or if the } \\
\text { patient's wait for } \\
\text { treatment would be life } \\
\text { threatening }\end{array}$ \\
\hline Québec & $\begin{array}{l}\text { Emergency services and the } \\
\text { costs derived from them }\end{array}$ & $\begin{array}{l}\text { No more than } 183 \text { days } \\
\text { outside Quebec during a } \\
\text { calendar year. } \\
\text { Exceptions are made for } \\
\text { working, pursuing } \\
\text { studies or taking training } \\
\text { outside of Quebec. } \\
\text { Spouses and dependents } \\
\text { accompanying } \\
\text { individuals falling in the } \\
\text { category of exception } \\
\text { also remain covered }\end{array}$ & $\begin{array}{l}\text { Only covers } \\
\text { prescriptions } \\
\text { during } \\
\text { hospitaliz- } \\
\text { ation }\end{array}$ & $\begin{array}{l}\text { Based on pre-established } \\
\text { rates, and on the reason } \\
\text { for and destination of } \\
\text { travel. Reimbursement } \\
\text { for hospitalization or } \\
\text { surgery, for ambulance } \\
\text { care }\end{array}$ \\
\hline Manitoba & Emergency services & $\begin{array}{l}\text { No more than } 183 \text { days } \\
\text { per calendar year }\end{array}$ & $\begin{array}{l}\text { Medicines } \\
\text { and prepar- } \\
\text { ations } \\
\text { approved by } \\
\text { the } \\
\text { Manitoba }\end{array}$ & $\begin{array}{l}\text { Based on pre-established } \\
\text { daily rates. Absences } \\
\text { from Manitoba } \\
\text { specifically to receive } \\
\text { medical treatments must } \\
\text { be pre-approved }\end{array}$ \\
\hline
\end{tabular}




\begin{tabular}{|c|c|c|c|c|}
\hline & & & $\begin{array}{l}\text { Minister of } \\
\text { Health }\end{array}$ & \\
\hline $\begin{array}{l}\text { British } \\
\text { Colombia }\end{array}$ & Emergencies & $\begin{array}{l}\text { Max- } 24 \text { months once in } \\
\text { five years }\end{array}$ & No & $\begin{array}{l}\text { Based on pre-established } \\
\text { rates, Reimbursement for } \\
\text { hospitalization }\end{array}$ \\
\hline Alberta & $\begin{array}{l}\text { Emergencies or pre-approved } \\
\text { services }\end{array}$ & $\begin{array}{l}\text { Max- } 6 \text { months. } \\
\text { Extensions for business, } \\
\text { missionary service, } \\
\text { sabbatical or educational } \\
\text { reasons }\end{array}$ & No & $\begin{array}{l}\text { Based on the provincial } \\
\text { rate }\end{array}$ \\
\hline $\begin{array}{l}\text { New } \\
\text { Brunswick }\end{array}$ & $\begin{array}{l}\text { Emergencies or pre-approved } \\
\text { services }\end{array}$ & $\begin{array}{l}\text { Max- } 12 \text { months once } \\
\text { every } 3 \text { years }\end{array}$ & No & $\begin{array}{l}\text { Based on pre-established } \\
\text { rates. Reimbursement for } \\
\text { hospital services, } \\
\text { radiology, laboratory and } \\
\text { interpretation fees }\end{array}$ \\
\hline $\begin{array}{l}\text { Newfound- } \\
\text { land and } \\
\text { Labrador }\end{array}$ & $\begin{array}{l}\text { Emergencies or pre-approved } \\
\text { services }\end{array}$ & $\begin{array}{l}\text { In accordance with the } \\
\text { plan, generally } 12 \\
\text { months }\end{array}$ & No & $\begin{array}{l}\text { Based on pre-established } \\
\text { rates. Reimbursement for } \\
\text { hospital services, } \\
\text { ambulances } \\
\text { Sudden illness }\end{array}$ \\
\hline $\begin{array}{l}\text { Nova } \\
\text { Scotia }\end{array}$ & $\begin{array}{l}\text { Emergencies, accidents and } \\
\text { sudden illness }\end{array}$ & Max 6 months & No & $\begin{array}{l}\text { Based on pre-established } \\
\text { rates. Reimbursement for } \\
\text { hospital services, } \\
\text { Sudden illness }\end{array}$ \\
\hline $\begin{array}{l}\text { Prince } \\
\text { Edward } \\
\text { Island }\end{array}$ & $\begin{array}{l}\text { Emergencies and sudden } \\
\text { illness }\end{array}$ & $\begin{array}{l}\text { Max } 12 \text { months, only } \\
\text { once, or } 6 \text { months every } \\
\text { year with previous } \\
\text { notification }\end{array}$ & N/A & $\begin{array}{l}\text { Based on pre-established } \\
\text { rates. Reimbursement for } \\
\text { hospital services }\end{array}$ \\
\hline $\begin{array}{l}\text { Saskatche- } \\
\text { wan }\end{array}$ & $\begin{array}{l}\text { Emergencies, psychiatric } \\
\text { emergencies, preapproved } \\
\text { services }\end{array}$ & Max 12 months & N/A & $\begin{array}{l}\text { Based on pre-established } \\
\text { rates. Reimbursement for } \\
\text { hospital services, } \\
\text { ambulances }\end{array}$ \\
\hline Yukon & $\begin{array}{l}\text { Emergency services, } \\
\text { professional doctors }\end{array}$ & Max 12 months & $\begin{array}{l}\text { Medicine } \\
\text { given in a } \\
\text { hospital }\end{array}$ & $\begin{array}{l}\text { Based on pre-established } \\
\text { rates. Reimbursement for } \\
\text { hospital services, } \\
\text { ambulances }\end{array}$ \\
\hline NWT & $\begin{array}{l}\text { Emergencies, medical } \\
\text { attention }\end{array}$ & $\begin{array}{l}\text { Max } 1 \text { year with } \\
\text { previous notification of } \\
\text { travel }\end{array}$ & $\begin{array}{l}\text { Depending } \\
\text { on the } \\
\text { service, } \\
\text { medicine } \\
\text { received is } \\
\text { covered }\end{array}$ & $\begin{array}{l}\text { Based on pre-established } \\
\text { rates. Reimbursement for } \\
\text { hospital services, } \\
\text { ambulances }\end{array}$ \\
\hline Nunavut & Emergencies & $\begin{array}{l}\text { Max 1 year with } \\
\text { previous notification of } \\
\text { travel }\end{array}$ & N/A & $\begin{array}{l}\text { Based on pre-established } \\
\text { rates. Reimbursement for } \\
\text { hospital services, } \\
\text { ambulances }\end{array}$ \\
\hline
\end{tabular}

Adapted from: Felicia Knaul, "Consultoría Para El Análisis De Costos Y Beneficios De Extender La Cobertura De Un Seguro Médico A Los Jubilados Estadounidenses Residentes En México” (paper presented to the Interamerican Development Bank, September 21, 2007), pp. 64-66. 


\begin{abstract}
Notes
${ }^{1}$ Health Canada, Canada Health Act - Frequently Asked Questions. Online. Available: http://www.hcsc.gc.ca/hcs-sss/medi-assur/res/faq-eng.php. Accessed: October 5, 2009.

${ }^{2}$ European Observatory on Health Systems and Policies, HiT Summary: Canada. Online. Available: www.euro.who.int/Document/E87954sum.pdf. Accessed: October 4, 2009.

${ }^{3}$ Health Canada, Canada's Health Care System (Medicare). Online. Available: http://www.hcsc.gc.ca/hcs-sss/medi-assur/index-eng.php. Accessed: October 3, 2009.

${ }^{4}$ Organization for Economic Cooperation and Development, "OECD Stat Extracts" database. Online. Available: http://stats.oecd.org/Index.aspx?DataSetCode=SNA_TABLE11. Accessed: April 28, 2010.

${ }^{5}$ European Observatory on Health Systems and Policies, HiT Summary: Canada. Online. Available: www.euro.who.int/Document/E87954sum.pdf. Accessed: October 4, 2009.

${ }^{6}$ Ibid.

${ }^{7}$ Health Canada, Canada's Health Care System (Medicare). Online. Available: http://www.hc-sc.gc.ca/ hcs-sss/medi-assur/index-eng.php. Accessed: October 3, 2009.

${ }^{8}$ Health Canada, Canada Health Act - Frequently Asked Questions. Online. Available: http://www.hcsc.gc.ca/hcs-sss/medi-assur/res/faq-eng.php. Accessed: October 5, 2009.

${ }^{9}$ Ibid.

${ }^{10}$ Ibid.

${ }^{11}$ Regie de l'assurance maladie Quebec, Leaving Quebec. Online. Available: http://www.ramq.gouv.qc. ca/en/citoyens/assurancemaladie/quitter/temporaire.shtml. Accessed October 5, 2009.
\end{abstract}


(this page intentionally left blank) 


\section{Chapter 8. Medicare Waiver}

\section{by Elizabeth Chmelik and Jennifer Schmalz}

As immigration from Mexico to the United States continues, the connection between the two countries deepens. Consequently, many Americans travel to Mexico to visit family or to retire. This includes Mexican-born naturalized citizens or legal permanent residents returning home. Often, these individuals work long enough in the United States to qualify for retirement benefits. Social Security benefits can usually be received outside of the United States via direct deposit or international bank accounts, but Medicare benefits are only available abroad in extremely limited circumstances. The Center for Medicare and Medicaid Services (CMS) can authorize a Medicare research and demonstration project tailored to provide emergency services to eligible beneficiaries in Mexico. This research and demonstration project would result in lower costs to Medicare and addresses issues of fairness, as beneficiaries have already paid into the system.

Medicare is divided into four parts with different qualification requirements, payment obligations, and services covered. Medicare guidelines require the recipient of benefits from any Medicare coverage be either a U.S. citizen or a "lawfully admitted non-citizen who has lived in the United States for at least five years."

Part A, also known as "hospital insurance," covers costs for inpatient hospital care, as well as skilled nursing facilities, hospice services, and some home health care. This Medicare benefit is available to most people over age 65 at no cost, although there are deductibles, copayments, and limits on some services.

Part B, or "medical insurance," covers physician services, outpatient hospital care, and some medical supplies, occupational/physical therapy, and home health care if medically necessary. Most people pay premiums for Part B, which may be adjusted based on income.

Part $\mathrm{C}$ encompasses the Medicare Advantage plans, which are HMOs or managed care products, and are optional. These plans receive premiums and payments from Medicare, and then provide services for patients. Each Medicare Advantage plan may have different benefits and coverage options but at a minimum must include the package of benefits provided under traditional Medicare.

Part D is prescription drug coverage. Again, this is arranged through intermediaries, different insurance companies that have different premiums, drug lists, and coverage. ${ }^{1}$

In general, Medicare only reimburses for medical care and health services provided within the United States. Medicare will, however, reimburse health care costs from outside of the United States in three unique situations:

1. When a beneficiary has a medical emergency in the U.S. and a foreign hospital is closer than the nearest U.S. hospital; 
2. When a beneficiary has a medical emergency while traveling through Canada by the most direct route between Alaska and another state, and the Canadian hospital is closer than the nearest U.S. hospital;

3. When a beneficiary lives in the U.S. and a foreign hospital is closer than the nearest U.S. hospital, regardless of whether it's an emergency. ${ }^{2}$

For an additional premium, beneficiaries may buy Medigap policies that offer additional coverage for health care outside the U.S. However, Medigap policies only cover beneficiaries for the first 60 days of travel. Additionally, Medigap policies have a lifetime limit of $\$ 50,000$ for all emergency foreign coverage. ${ }^{3}$ Medicare Advantage plans also cover individuals for the first 60 days of travel. However, individuals who live abroad for more than six months of the year are not eligible to purchase either Medigap or Medicare Advantage plans. If not covered by one of these plans, retirees often must cover the costs of emergency care with their savings or forgo care altogether. While some patients choose to return to the United States on a regular basis for primary care, this is not an option in an emergency situation. Some retirees choose to enroll in IMSS, the Mexican Social Security Medical coverage, but this option is not available to temporary visitors and does not cover preexisting conditions. Additionally, insurance programs exist in Mexico but often have age limits on purchasing a policy, and bureaucracies that are difficult to navigate. ${ }^{4}$

Section 402 of Public Law 92-603 grants CMS the authority to approve Medicarewaiver-only demonstrations. These demonstrations assess the potential of adjustments of service coverage for "improving access and quality and/or lowering health care costs." Specifically, Section 402 allows CMS to waive payment and benefit statutes in pursuance of demonstrating these new initiatives. New initiatives may include new benefits, feefor-service payment models, Medicare Advantage payment methodologies, or risk sharing arrangements. A Congressional mandate can also initiate a demonstration project. $^{5}$

Waiver demonstration projects must be budget neutral, in that the expected costs must not exceed costs were the demonstration not implemented. ${ }^{6}$ Both of these objectives can be met in a waiver project expanding Medicare services to cover emergency care in Mexico. The expansion of Medicare benefits to Mexico is important because of the large numbers of Mexicans immigrants in the United States. These immigrants frequently travel back to Mexico to visit family. In this vein, our survey of Mexican-born persons primarily living in the United States found that two-thirds of respondents have family in Mexico. Of the nearly one-quarter of respondents who are not yet retired and receiving Medicare or Social Security benefits, 75 percent expect to receive Medicare and Social Security benefits in the future. As a result, the majority of respondents reported that they plan to retire in the United States. Additionally, six percent of the elderly group reported that they received no health care at all (See Chapter 9). In addition, many native U.S. citizens choose to retire to Mexico to benefit from the lower cost of living. Both groups qualify for Medicare and may benefit from a mechanism in place to access Medicare in Mexico. 
To this end, CMS could authorize a project in which emergency medical care would be covered in Mexico for all Medicare recipients.

Congressional proposals during the health care reform included the creation of a Center for Medicare and Medicaid Innovation (CMI). The CMI would test innovative payment and service-delivery models to reduce expenditure without sacrificing the quality. CMI differs from the current CMS system in several aspects. The first is that CMI would run pilot programs, rather than demonstration projects. The secretary of Health and Human Services would be granted the authority to expand pilot programs. Second, CMI would have considerably more flexibility in its ability to select programs. Finally, CMI would not require that projects be budget-neutral during the testing period. ${ }^{7}$

\section{Possible Demonstration Models}

Several U.S. health care benefit programs already routinely reimburse care received in Mexico. Primary among these are Tricare, which covers military dependents and retirees, and the Foreign Medical Program in the Department of Veterans Affairs (VA). The VA only covers care related to service-connected disabilities and five years of postseparation comprehensive care for veterans of the Global War on Terror. ${ }^{8}$ In fiscal year 2008, the VA covered the costs of health care for 33 Mexican residents, totaling $\$ 130,294$. In 2008, Tricare covered 388 non-Mexico residents who received care in Mexico amounting to $\$ 640,072$ in claims. Additionally, 176 Mexican residents received care through Tricare in 2008 for claims totaling $\$ 917,647 .{ }^{9}$ While the Tricare system and infrastructure offers the most potential for providing health care for public health care beneficiaries in Mexico, the system also has a number of significant limitations. Tricare does not have any permanent medical facilities in Mexico, and is less organized than in other countries that do have permanent facilities. In addition, the Tricare system is relatively small in Mexico because of the lack of U.S. military infrastructure. Moreover, Tricare is consumer-driven. The provider bills the recipient directly and the beneficiary sends documentation to a separate contracted vendor, assigned to their geographic region for reimbursement. As a result, the Tricare system does not adequately control for cost or fraud. ${ }^{10}$

The proposed Medicare research and demonstration project could follow three potential options for design:

1. Emergency care only,

2. Coverage in Mexico if the beneficiary agrees to only receive care in Mexico, or

\section{Extension of comprehensive care to Mexico.}

While comprehensive medical care for Medicare beneficiaries in Mexico may eventually be provided, it is more rational to begin with a demonstration project for emergency care. Covering emergency services is the most politically feasible and most practical option to implement. In the absence of Medicare benefits in Mexico, beneficiaries must often cover the costs of emergency care with their own savings or forgo care. Providing 
Medicare benefits in Mexico for emergencies averts a potentially dangerous situation that can arise when a patient forgoes treatment. A provision for emergency services would allow beneficiaries to receive necessary medical services in Mexico in circumstances where it would prove difficult to travel back to the United States for treatment.

The passage of the Emergency Medical Treatment and Labor Act (EMTALA) in 1986 set a precedent for the coverage of emergencies in the United States. Passage of this law served to curtail the practice of treating patients differently based on ability to pay. If a patient presents to any emergency room in a hospital that accepts Medicare payments, that patient must now receive at least a medical screening exam with any ancillary services to determine if an emergency medical condition exists. If such an emergency does indeed exist or the patient is in labor, that hospital must either provide appropriate medical care to stabilize the patient or arrange transfer to another facility if the needed services cannot be provided at that hospital. For example, if a patient arrives at an emergency room complaining of chest pain, the hospital is obligated to examine the patient, perform any laboratory or imaging tests required to rule out an emergency condition, and provide access to cardiology care if needed. Patients may not be treated differently based on insurance coverage or lack thereof, and hospitals may fined up to $\$ 50,000$ if found in violation of this act. ${ }^{11}$

A demonstration project could be tailored to cover defined emergencies, such as chest pain, fractures, pneumonia, abdominal pain, and syncope or fainting-medical conditions for which delay in care could result in significantly increased morbidity and mortality. For example, if a patient does not seek care for symptoms of severe abdominal pain that may signify appendicitis, the end result could be a rupture of the appendix leading to an intra-abdominal infection requiring more extensive surgery, a longer hospital stay, and increased risk of death. Likewise, timely treatment of a heart attack with anti-clotting drugs or surgical intervention can reduce the risk of heart failure, arrhythmias, and death. The causes of syncope are numerous, but include life-threatening causes such as an irregular heartbeat or a heart valve defect that may require immediate intervention with pacemaker placement or surgery. In addition, other urgent care situations could be covered, such as fever, cough, or urinary tract infection. Medicare could choose not to pay claims if certain criteria are not met for an emergency situation; this is similar to procedures in the United States to deny coverage for ambulance transportation or even self-referred care in an emergency room if determined to not be an emergent need.

In an emergency situation under this proposal, the patient would go to the emergency room of a hospital in Mexico and receive stabilizing care. Ideally, Medicare would preapprove hospitals in Mexico using a set of guidelines developed in conjunction with Joint Commission International (JCI) or another similar organization. These hospitals would be identified on the Medicare website and selected in areas with large numbers of Americanborn and Mexican-American retirees. Networks such as Blue Cross/ Blue Shield $(\mathrm{BC} / \mathrm{BS})$ provide an initial framework for determining which hospitals are capable of providing emergency services. However, in an emergency situation it may not be possible for a beneficiary to go to a hospital in this network. In this case, accommodations would be made to cover the care received. 
Reimbursement rates would be negotiated with the network of hospitals through a qualified intermediary familiar with the Mexican health care market. Again, it is preferable for a patient to access a hospital in this network, but not mandatory. In some cases, the patient would be responsible for notifying Medicare or the fiscal intermediary of their emergency and transfer might be arranged to an in-network facility if hospitalization or more extensive care is required. Notification of Medicare beneficiaries about this demonstration project could be accomplished via mail, with the same information available on the Medicare website and in the "Welcome to Medicare" booklet. Participation in the project by the patient would be on a voluntary basis. The waiver participants would still pay their part B premiums, which would generate additional revenue for the Medicare program. Part B would be required for participants in the waiver program because individuals residing in Mexico would be less likely to keep their Part B payments current without this requirement. Currently, seniors may choose to not pay these premiums, especially if not living in the United States where they would be more likely to access care.

Timely medical care would be administered and the patient discharged with appropriate follow-up until they are able to return back the United States to see their primary care physician if they choose. Documentation requirements would be defined for the hospitals and physicians in Mexico, and translation to English would be required through the intermediary. Reimbursements to the hospital could follow the same diagnosis-related group payment as facilities in the United States, be paid on a daily basis similar to critical access hospitals, or follow procedures already in place where insurance companies do provide coverage in Mexico. However, the payment schedule would be adjusted to reflect the local rates in Mexico. A qualified intermediary, such as CIGNA or BC/BS, that is familiar with the Mexican health care market may be used to help facilitate payment and negotiate rates.

Providing emergency services through Medicare may also meet CMS's objective of budget neutrality. Health care costs are currently much lower in Mexico than in the United States, estimated at between a 35 to 80 percent savings, depending on the variety of services chosen. ${ }^{12}$ Perhaps more significant, these services are often delivered with a quality of care that would satisfy Medicare regulations. Both public and private hospitals in Mexico are adopting measures that would be similar to those in the United States, including licensing requirements. Over recent years, more hospitals in Mexico have qualified for certification by the JCI (www.jointcommissioninternational.org) and other organizations that oversee quality and patient safety initiatives in hospitals worldwide. Part of this certification includes the approval of physicians working at these hospitals. Studies show that many Americans receiving medical care in Mexico are pleased with the quality, level of personal attention and low costs. ${ }^{13}$ This pilot program can serve to permit CMS officials to determine if Medicare dollars are going to qualified professionals and organizations, while maintaining high patient satisfaction. Because the care would be given for emergency situations, this option would lessen or eliminate many of the issues related to oversight and accreditation. This option is also most politically feasible in that the services would not compete with U.S.-based health care. It would also apply to a broader population: both visitors to Mexico who do not have Medigap or Advantage 
plans, those who have visited for more than 60 days, and retirees in Mexico who are not able to purchase such coverage.

Emergency services also relate to issues of fairness and equity. Beneficiaries who have worked in the United States long enough to qualify for Medicare should not be subjected to exorbitant out-of-pocket payments for emergency care that could not be anticipated or prevented. If a person who qualifies for Medicare benefits is outside of the country and suffers a medical emergency, the health insurance they are entitled to should cover the cost of care. The fear of a large medical bill should not be an impediment in obtaining urgent assistance. Some travel insurances reimburse for the use of air ambulance services to bring a patient back to the United States, but the cost of providing care at the foreign location most likely would be less costly than transferring the patient to a domestic facility.

Further, most western developed countries already provide for emergency care outside of the country through the extension of their social insurance schemes. For example, provincial health insurance plans in Canada provide emergency services while a beneficiary is traveling outside the country (see Chapter 7). Similarly, as delineated in Chapter 6, most countries in Europe not only cover care received in other European countries but also often provide emergency and urgent coverage outside of Europe as well.

\section{Other Options for a Waiver}

Another option for a waiver proposal would be coverage for all care in Mexico if the eligible beneficiary agreed to receive all care in Mexico, forgoing their primary care benefit in the United States under Part B. Past examples of proposals for the expansion of Medicare include the proposal by Americans for Medicare in Mexico (ANMAC). Paul Crist, the principal organizer of ANMAC, proposed a three-year research and demonstration project in which beneficiaries would agree to receive all their health care through the project. Under this proposal, enrollees would receive all of their medical care under Medicare Parts A and B with hospitals and physicians in Mexico approved by JCI or a similar organization. Again, a fiscal intermediary familiar with the health care landscape in Mexico would be given the responsibility of enrolling patients, certifying providers, negotiating rates, and providing data to CMS to track quality and costeffectiveness of such a project.

In contrast to emergency coverage that would be beneficial to all Medicare recipients traveling to Mexico for various reasons, a waiver that encompassed primary care benefits would be targeted more to those who have chosen to retire to Mexico. By forgoing access to medical benefits in the United States, these participants would most likely need to be full-time residents of Mexico. In addition, the initial targeted audience likely would be American retirees in Mexico rather than returning Mexican-born citizens. Some of the hospitals receiving JCI accreditation are in areas that traditionally attract American retirees. If the program were found to be successful, expansion into more rural areas would then be feasible. 
The cost savings under this proposal would come from the overall reduced cost of health care services in Mexico. Medicare recipients would still be responsible for paying their Part B premiums, which would then go to cover a portion of the physician services and other outpatient needs in Mexico and offset some of these costs. Retirees who live in Mexico may forgo primary care or to pay out-of-pocket for these costs currently, but there are those that return to the United States on a regular basis for physician visits and to fill prescriptions. Under the terms of this pilot, these retirees would receive all care in Mexico and would forgo coverage for care received in the United States. One concern is that the costs of health care may rise in Mexico for all people, not just Medicare recipients, once there is increased demand for services and more involvement of a thirdparty payer. In addition, once access and payment are ensured, there is the possibility that health care utilization may change for the retirees in Mexico, so their usage of services may increase from current levels.

The Association of American Residents Overseas (AARO) proposed the relaxation of rules for Americans who retire overseas after contributing to the Medicare system.

AARO suggests the use of Tricare Standard to provide health care for American civilians or a research and demonstration project. AARO argues that in addition to inconveniencing Americans, the cost of providing Medicare to Americans abroad would be less costly to the Treasury because of the less expensive health care costs abroad. As evidence, AARO cites the successful implementation of Tricare Standard in Mexico. Tricare provides medical and hospitalization services at a lower price than the scheduled Medicare costs in the United States. AARO also contends that Tricare has spurred the adoption of medical standards in Mexico. ${ }^{14}$

In addition, AARO advocates an exemption on the late penalties for enrollment in the case of Americans living abroad. Rather than being penalized for enrolling late, the individual would enroll when they return to the United States without a penalty. AARO also encourages the adoption of automated health care information to facilitate the transfer of patient information and documentation between countries for Medicare beneficiaries. $^{15}$

During a meeting of the North American Free Trade Agreement (NAFTA) Financial Services Committee in November 2007, the Mexican government prompted a discussion of extending Medicare coverage to U.S. citizens and permanent residents living in Mexico. The Mexican government pointed out the difference in the aging populations of the U.S. and Mexico, with those over 65 being a much larger proportion of the U.S. population. Increasing health care access for retirees was seen as a motivating factor to encourage more retirees to move to Mexico. The Mexicans recognize the lower cost of health care overall in Mexico and the potential benefits to the Medicare system if some of these costs could be shifted into Mexico. In addition, there was thought to be potential for expansion of medical services into the Mexican health care market and room for investment in their systems. ${ }^{16}$

The 2007 Policy Research Project on Medicare in Mexico focused on the use of health care among Americans retired in Mexico. The project contended that lack of access to 
health care, specifically Medicare, has a significant effect on the decisions of Americans regarding retirement. If American retirees in Mexico could access their Medicare benefits, more individuals would retire to Mexico and those already retired would stay in Mexico for longer periods of time. ${ }^{17}$

The project surveyed 1,025 people retired in Mexico. Individuals retired in Jalisco, Guanajuato and Sinaloa accounted for 75 percent of responses. Of the respondents, 73 percent had lived in Mexico for 10 to 12 months of each year. The survey asked respondents if they planned to return to the United States. Eighty-six percent of respondents indicated they did not plan to return permanently. The respondents who did plan to return to the U.S. cited their primary motivation in wanting to return to the United States as the economic and logistics-issues related to health care.

In order to determine the impact of Medicare expansion on Americans retired in Mexico, the project recommended a Medicare research and demonstration project. The communities of U.S. retirees near Lake Chapala and in Guadalajara, Jalisco, San Miguel de Allende, Guanajuato or the area of Baja California south of Tijuana are suggested to serve as the sample groups for a Medicare study in Mexico.

Beyond Mexico, the Commission on Filipinos Overseas (CFO) has lobbied the U.S. government to extend Medicare benefits to the Philippines. The CFO is primarily concerned with access to health care for Filipinos living in the United States who wish to move back to the Philippines when they retire. The CFO estimates that currently approximately two million Filipinos live in the U.S. as either U.S. citizens or landed permanent residents. The case for extension of Medicare benefits to the Philippines is reinforced by the ability of Medicare recipients in Guam and the Commonwealth of the Northern Mariana Islands to receive coverage for medical care in the Philippines for emergencies and necessary interventions not available in Guam and Saipan.

Additionally, Congress recently granted increased health benefits for Filipino World War II veterans. The Philippine Retirement Authority signed a Memorandum of Understanding with Health Care Options U.S.A. allowing the receipt of certain medical benefits under Medicare and Social Security in the Philippines. ${ }^{18}$ Also, Manila in the Philippines is the location of the only VA hospital outside of the U.S.

\section{Payment Methodology and Budget Neutrality}

A fiscal intermediary would be required to conduct a research and demonstration project in Mexico. Bair and Waters identify four necessary characteristics for a fiscal intermediary in Mexico: it must meet standards set by CMS, maintain a national infrastructure, have the ability to process claims, and create and maintain a fraud prevention system.

Using a U.S. insurance company, such as Blue Cross/Blue Shield (BC/BS) would meet these standards. Other large American health insurance companies, such as United Healthcare or Aetna would also meet these requirements. The only requirement these companies are not prepared to fulfill in Mexico is to enroll beneficiaries. This limitation 
is insignificant because beneficiaries must enroll in Medicare and Social Security in the United States.

BC/BS already identifies providers in countries outside the U.S. that meet standards to include in their network. Currently, BC/BS has 357 providers in their international network. The company provides assistance to beneficiaries abroad 24 hours a day, 7 days a week. A beneficiary abroad can call $\mathrm{BC} / \mathrm{BS}$ and receive assistance in locating a provider. $\mathrm{BC} / \mathrm{BS}$ will also make appointments in cases where the patient needs assistance navigating the language.

In cases of outpatient treatment (defined as treatment lasting less than 24 hours), BC/BS reimburses the patient for treatment and contracts with a medical services company to provide translation and currency conversion of all foreign receipts. In cases of treatment lasting more than 24 hours, $\mathrm{BC} / \mathrm{BS}$ appoints beneficiaries a nurse to monitor their treatment. Additionally, the company often contacts with the provider to arrange direct payment.

Since BC/BS often serves as the fiscal intermediary for health care in the United States that meets the standards of CMS, it would be equipped to meet any new standards set by CMS in the implementation of a research and demonstration project in Mexico.

Further, $\mathrm{BC} / \mathrm{BS}$ has an infrastructure already established in the U.S. This infrastructure includes the ability to process international claims. In order to reimburse claims, $\mathrm{BC} / \mathrm{BS}$ has a system to prevent fraud in place (the major component being to insure that services were received).

Given the increasing demand for health insurance in Mexico, this position as a fiscal intermediary could be competitive with both U.S. and Mexican health insurance companies able to bid.

Utilizing a company that already meets the requirements as an intermediary greatly reduces the cost of a research and demonstration project. Neither the intermediary nor CMS would have to invest in the development of capacities to meet these requirements. Budget neutrality would also be insured by the small relative frequency of emergencies among Medicare beneficiaries. The number of annual emergencies among beneficiaries in Mexico would be relatively low. Additionally, the cost of emergency services would be significantly lower than the services in the U.S. Thus, both the beneficiaries and the Medicare system would save considerably money.

Any costs associated with emergency services for beneficiaries would also be somewhat offset by an additional requirement for beneficiaries to pay into Medicare Part B to be eligible for Medicare reimbursement for emergencies services in Mexico. If the Medicare beneficiary were to receive either all or part of their primary care in Mexico, this would also result in cost savings with overall costs being lower in Mexico and less services being accessed in the United States. 
In addition, retiring to Mexico is attractive for many because of the lower cost-of-living which enables people to limit costs of all expenses, not just health care but also food and housing. Some of these retirees qualify for Medicaid benefits as well, which would be forfeited if they move to Mexico. This may be revenue-neutral for the retiree and not adversely affect their decision to move, especially if able to afford in-home care or other services in Mexico. A retiree of lower income level or with less savings would likely be able to afford a higher quality of life in Mexico than if remaining in the United States. This would positively impact the Medicaid program with reduced need for long-term residential care payments, nursing home, or prescription drug coverage, common uses of Medicaid for the elderly population in the United States.

\section{Performance Results}

Asirifi and Rodriguez suggest three areas to consider in evaluating the cost-effectiveness of a demonstration project:

\section{Travel costs,}

2. the reimbursement rate for health care in Mexico, and

3. whether preventative care reduces health care costs or whether the "higher quality" of U.S. health care lead to lower costs in the long term ${ }^{19}$

The results expected from a research and demonstration project for Medicare in Mexico would include an improvement in the care received by beneficiaries and a reduction in costs associated with health care outside of the U.S. for both CMS and beneficiaries.

If Medicare beneficiaries can access their benefits when they are in Mexico, they will no longer be forced to choose between paying costs out of pocket or forgoing care. Since most retired beneficiaries in Medicare live on a fixed income, paying out of pocket for health care services is often cost prohibitive. Forgoing treatment, particularly in an emergency, leads to decreased health outcomes.

The cost of health care in Mexico is significantly lower than in the United States. Thus, a research and demonstration project in Mexico could result in savings for CMS and the beneficiaries. These costs will be both in terms of health care costs as well as travel costs.

Asirifi and Rodriguez suggest evaluating the cost-effectiveness of a demonstration project through the use of a control group and benchmarking. The control group would allow for comparison between groups using Medicare covered services in Mexico versus those who are not. In practice, the use of a control group may be difficult to manage, as the question of who to include in the group may be difficult to navigate. Benchmarking would allow for comparison across groups by adjusting the costs for age, disability, and gender. $^{20}$ 


\section{Notes}

${ }^{1}$ Department of Health and Human Services, Medicare Basics. Online. Available: http://www.medicare. gov. Accessed: September 22, 2009.

${ }^{2}$ Center for Medicare and Medicaid Services, Medicare Coverage Outside the United States. Online. Available: http://www.medicare.gov/publications/pubs/pdf/11037.pdf. Accessed: January 24, 2010.

${ }^{3}$ Ibid.

${ }^{4}$ Sara Ross, Jose Pagan, and Daniel Polsky, "Access to Health Care for Migrants Returning to Mexico," Journal of Health Care for the Poor and Underserved (2006), pp. 374-385.

${ }^{5}$ Center for Medicare and Medicaid Services, Medicare Waiver Demonstration Application. Online. Available: https://www1.cms.hhs.gov/cmsforms/downloads/cms10069.pdf. Accessed: January 24, 2010.

${ }^{6}$ Ibid.

${ }^{7}$ Robert Mechanic and Stuart Altman, "Medicare's Opportunity to Encourage Innovation in Health Care Delivery," New England Journal of Medicine, March 4, 2010, pp. 772-774.

${ }^{8}$ United States Department of Veterans Affairs, Veterans Services. Online. Available: http://www.oefoif. va.gov. Accessed: April 20, 2010.

${ }^{9}$ David Warner and Lauren Jahnke, "U.S.-Mexico Mode 2 Imports and Exports of Health Services" (paper presented to the Organization for Economic Cooperation and Development, Marseille, France, March 3, 2010), p. 7.

${ }^{10}$ Jason Bair and Hayley Waters, "Paper II: Models for Administering Medicare Benefits," in Three Technical Papers on a Research and Demonstration Waiver for Medicare Coverage in Mexico, ed. Policy Research Project on Medicare Payment for Medical Services in Mexico, pp. 32-34.

${ }^{11}$ U.S. Congress, Social Security Act, Section 1867 of the Social Security Act (42 U.S.C. 1395dd). Online. Available: http://www.ssa.gov/OP_Home/ssact/title18/1867.htm\#t. Accessed: April 21, 2010.

${ }^{12}$ Americans for Medicare in Mexico, Cost Saving. Online. Available: http://www.medicareinmexico.org/ cost_saving.html. Accessed: January 19, 2010.

${ }^{13}$ Lyndon B. Johnson School of Public Affairs, Medicare in Mexico: Innovating for Fairness and Cost Savings, Policy Research Project Series, no. 156 (The University of Texas at Austin: Austin, Tex., 2007), p. 113.

${ }^{14}$ Association for Americans Residents Overseas, Medicare for Overseas. Online. Available: http://aaro.org/position-papers-2010/medicare-for-overseas-americans-2010. Accessed: April 20, 2010.

${ }^{15}$ Ibid. 
${ }^{16}$ Unidad de Seguros Valores y Pensiones, Secretaría de Hacienda y Crédito Público, "Proposal to Extend Medical Insurance Coverage to eligible U.S. Citizens and Permanent Residents living in Mexico," 13th Annual NAFTA Financial Services Committee Meeting and SPP Financial Services Working Group Meeting (Mexico City, Mexico, November 13, 2007), pp. 1-4.

${ }^{17}$ Lyndon B. Johnson School of Public Affairs, Medicare in Mexico: Innovating for Fairness and Cost Savings, Policy Research Project Series, no. 156 (The University of Texas at Austin: Austin, Tex., 2007).

${ }^{18}$ Email from the Commission for Filipinos Overseas, "Portability of U.S. Health Care," to Jennifer Schmalz, February 5, 2010.

${ }^{19}$ Carolina Asirifi and Reymundo Rodriquez, "Paper III: How to Evaluate Cost Savings," in Three Technical Papers on a Research and Demonstration Waiver for Medicare Coverage in Mexico, Policy Research Project Series, no. 7 (The University of Texas at Austin: Austin, Tex., 1999), pp. 62-66.

${ }^{20}$ Ibid., pp. 64-65. 


\title{
Chapter 9. Survey Methodology and Results
}

\author{
by Robin Lynch and Lisa Morgan Wallace
}

\section{Survey Methodology}

In order to better understand the situation of elderly persons who were born in Mexico but have lived in the United States for an extended period of time, we distributed surveys in a number of ways and received a variety of responses. We hoped to find out why people choose the place they have chosen to retire and what factors have influences their decision. We included questions regarding retirement status, what benefits they receive, where their primary residence is, whether they have family in Mexico, where they receive health care, where they would prefer to retire, and what are their reasons for choosing where to retire. We distributed the survey in both paper and online form, in both an English and Spanish format. The surveys were anonymous and participation was voluntary. We specifically targeted locations and organizations where we would most likely find the population we are interested in. Often we needed to help with filling out surveys due to literacy barriers. The places we distributed surveys included:

- The Brady Center, a senior center run by Catholic Charities in Dallas, Texas,

- La Voz del Anciano, an organization devoted to serving the needs of the elderly Hispanic population in Dallas,

- Two home town associations, organizations devoted to raising money for infrastructure projects in home communities in Mexico,

- Two communities in the state of Guanajuato which were visited by three members of the research group in December 2009.

All survey responses used contained at least five completed question responses, and those not meeting the criteria were dropped from the survey analysis. Because respondents were not required to answer all questions, those left unanswered of the remaining qualifying surveys were dropped from total counts for the corresponding question. Analysis was conducted for each participation group as well as the entire participant population.

\section{Results}

Just over 100 individuals residing in United States, Mexico, or both were surveyed using both the paper and online survey. Of these, 33 responses were submitted online from various cities throughout Texas, California, Washington, Illinois, Florida, and Mexico. The paper surveys were distributed and collected onsite with the Hispanic community groups described above. 
Dallas surveys were conducted at the Catholic Charities' Brady Senior Center. This population is largely over the age of 65 , mostly female, retired, and living as citizens in the United States. Eighty-two percent of survey respondents receive Medicare benefits, and 41 percent benefit from Medicaid to cover health care and long term care costs. Likewise, 82 percent receive Social Security retirement payments, and 26 percent receive Supplemental Security Income (SSI) as a result of having little or no personal income in addition to Social Security. Of the nearly one quarter of respondents who are not yet retired and on Medicare or Social Security, 75 percent expect to receive Medicare and Social Security benefits in the future. Despite their participation at an American senior center, 5 percent live primarily in Mexico, another 5 percent have primary residences in both countries, and one quarter of all respondents have family remaining across the border in Mexico, with most families residing in the Mexican state of Nuevo Leon. Most receive their health care services in the United States and plan to stay retired there due to their heavy reliance on Medicare and Medicaid, but a disturbing 6 percent of the elderly group received no health care at all. One individual specifically describes a process in which he lives in Mexico while having Medicare benefits for which he returns to the United States three times per year. While he is north of the Mexican border, his physician gives him at least three months of medicine to last until his next trip across the border. Most individuals prefer retirement in the United States (Figure 9.1). Factors most influencing the decision about where to retire include proximity to family members and access to Medicare benefits (Figure 9.2). Many also consider living costs when making the decision about where to live, though access to public health benefits and other social welfare benefits in the United States had a significant impact on perceived cost, making it a cheaper place to live than Mexico for many.

\section{Figure 9.1}

Retirement Location Preference (Brady Center, Dallas, Texas)

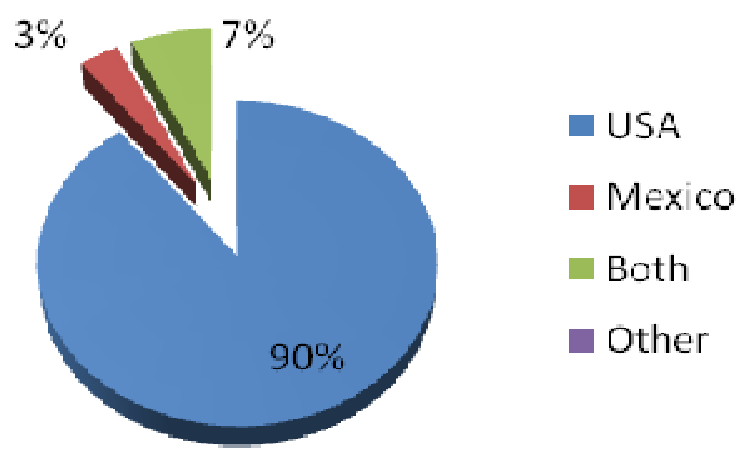


Figure 9.2

Reasons for Retirement Preference (Brady Center, Dallas, Texas)

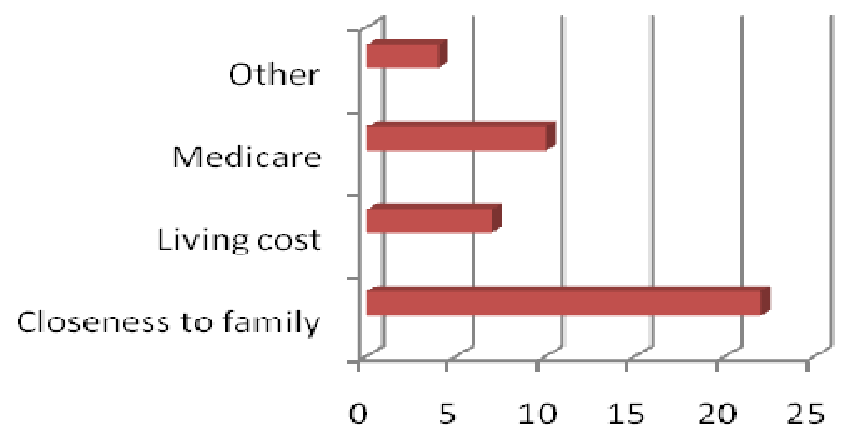

Table 9.1

Dallas Survey Responses

\begin{tabular}{|c|c|c|c|}
\hline & & \multicolumn{2}{|c|}{ Dallas } \\
\hline & & Individuals & Percent \\
\hline \multicolumn{4}{|l|}{ Age } \\
\hline & $0-49$ & 0 & $0 \%$ \\
\hline & $50-64$ & 6 & $15 \%$ \\
\hline & $65+$ & 33 & $85 \%$ \\
\hline \multicolumn{4}{|l|}{ Gender } \\
\hline & Male & 11 & $28 \%$ \\
\hline & Female & 28 & $72 \%$ \\
\hline \multicolumn{4}{|c|}{ Retirement status } \\
\hline & Retired & 23 & $62 \%$ \\
\hline & Semi-retired & 4 & $11 \%$ \\
\hline & Not retired & 10 & $27 \%$ \\
\hline \multicolumn{4}{|c|}{ Benefits receiving } \\
\hline & Medicare & 32 & $82 \%$ \\
\hline & Medicaid & 16 & $41 \%$ \\
\hline & SS & 32 & $82 \%$ \\
\hline & SSI & 10 & $26 \%$ \\
\hline & None & 2 & $5 \%$ \\
\hline & Not Sure & 0 & $0 \%$ \\
\hline \multicolumn{4}{|c|}{ Benefits that will receive later } \\
\hline & Medicare & 9 & $23 \%$ \\
\hline & Medicaid & 0 & $0 \%$ \\
\hline & SS & 8 & $21 \%$ \\
\hline & SSI & 2 & $5 \%$ \\
\hline & None & 0 & $0 \%$ \\
\hline & Not Applicable & 27 & $69 \%$ \\
\hline & Not Sure & 0 & $0 \%$ \\
\hline
\end{tabular}




\begin{tabular}{|c|c|c|c|}
\hline \multicolumn{4}{|c|}{ Primary Residence } \\
\hline & USA & 34 & $89 \%$ \\
\hline & Mexico & 2 & $5 \%$ \\
\hline & Both & 2 & $5 \%$ \\
\hline & Other & 0 & $0 \%$ \\
\hline \multicolumn{4}{|c|}{ Family in Mexico } \\
\hline & Yes & 24 & $62 \%$ \\
\hline & No & 15 & $38 \%$ \\
\hline \multicolumn{4}{|c|}{ Where does your family live in Mexico? } \\
\hline & Jalisco & 1 & $5 \%$ \\
\hline & Tamaulipas & 5 & $24 \%$ \\
\hline & Mexico State & 1 & $5 \%$ \\
\hline & Guanajuato & 5 & $24 \%$ \\
\hline & Coahuila & 1 & $5 \%$ \\
\hline & Nuevo Leon & 7 & $33 \%$ \\
\hline & Baja California Sur & 0 & $0 \%$ \\
\hline & Chihuahua & 1 & $5 \%$ \\
\hline & Sinaloa & 0 & $0 \%$ \\
\hline & Navarit & 0 & $0 \%$ \\
\hline & Puebla & 0 & $0 \%$ \\
\hline \multicolumn{4}{|c|}{ Where health care received } \\
\hline & USA & 32 & $89 \%$ \\
\hline & Mexico & 1 & $3 \%$ \\
\hline & Both & 1 & $3 \%$ \\
\hline & Other & 0 & $0 \%$ \\
\hline & None & 2 & $6 \%$ \\
\hline \multicolumn{4}{|c|}{ If not retired, where do you plan to? } \\
\hline & USA & 13 & $81 \%$ \\
\hline & Mexico & 1 & $6 \%$ \\
\hline & Both & 2 & $13 \%$ \\
\hline & Other & 0 & $0 \%$ \\
\hline \multicolumn{4}{|c|}{ Where would you prefer to retire? } \\
\hline & USA & 26 & $90 \%$ \\
\hline & Mexico & 1 & $3 \%$ \\
\hline & Both & 2 & $7 \%$ \\
\hline & Other & 0 & $0 \%$ \\
\hline \multicolumn{4}{|c|}{$\begin{array}{l}\text { What factors influence your reasons to } \\
\text { retire? }\end{array}$} \\
\hline & Closeness to family & 22 & $71 \%$ \\
\hline & Living cost & 7 & $23 \%$ \\
\hline & Medicare & 10 & $32 \%$ \\
\hline & Other & 4 & $13 \%$ \\
\hline \multicolumn{4}{|c|}{ US citizen? } \\
\hline & USC & 30 & $94 \%$ \\
\hline & Not a USC & 2 & $6 \%$ \\
\hline \multicolumn{4}{|c|}{ Spouse a US citizen? } \\
\hline & \begin{tabular}{|l} 
Spouse a USC \\
\end{tabular} & 15 & $48 \%$ \\
\hline & Spouse not a USC & 16 & $52 \%$ \\
\hline \multicolumn{4}{|c|}{ Permanent Resident? } \\
\hline & LPR & 2 & $100 \%$ \\
\hline & Not an LPR & 0 & $0 \%$ \\
\hline \multicolumn{4}{|c|}{ Spouse a Permanent Resident? } \\
\hline & Spouse an LPR & 1 & $100 \%$ \\
\hline & Spouse not an LPR & 0 & $0 \%$ \\
\hline
\end{tabular}


Pasadena survey participants were contacted through a home town association we met while attending a meeting held by a representative of the Guanajuato state government in Houston in November of 2009. Most of these individuals are either U.S. citizens or married to a citizen, and 44 percent of the respondents are over the age of 65, retired and on Medicare and Social Security. Those who are not yet retired expect such benefits upon reaching eligibility. Only one of these individuals lives permanently in Mexico, and all have family in the Mexican state of Guanajuato. Two thirds plan to retire to Mexico (Figure 9.3), but all of those polled are influenced most in retirement decisions by access to Medicare, as they currently receive their health care in the United States.

Figure 9.3

\section{Planned Retirement Location (Pasadena, Texas)}

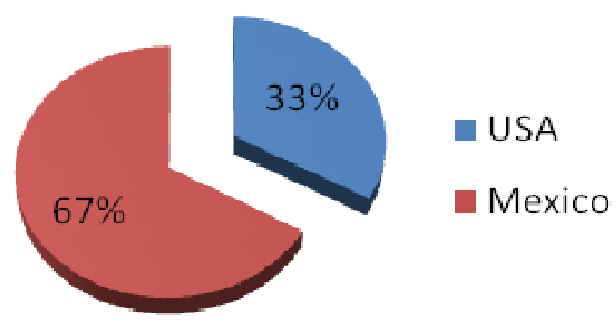

Table 9.2

Pasadena Survey Responses

\begin{tabular}{|c|c|c|c|}
\hline & & \multicolumn{2}{|c|}{ Pasadena } \\
\hline & & Individuals & Percent \\
\hline \multicolumn{4}{|l|}{ Age } \\
\hline & $0-49$ & 3 & $33 \%$ \\
\hline & $50-64$ & 2 & $22 \%$ \\
\hline & $65+$ & 4 & $44 \%$ \\
\hline \multicolumn{4}{|l|}{ Gender } \\
\hline & Male & 0 & - \\
\hline & Female & 0 & - \\
\hline \multicolumn{4}{|c|}{ Retirement status } \\
\hline & Retired & 4 & $44 \%$ \\
\hline & Semi-retired & 0 & $0 \%$ \\
\hline & Not retired & 5 & $56 \%$ \\
\hline \multicolumn{4}{|c|}{ Benefits receiving } \\
\hline & Medicare & 4 & $44 \%$ \\
\hline
\end{tabular}




\begin{tabular}{|c|c|c|c|}
\hline & Medicaid & 0 & $0 \%$ \\
\hline & SS & 5 & $56 \%$ \\
\hline & SSI & 0 & $0 \%$ \\
\hline & None & 4 & $44 \%$ \\
\hline & Not Sure & 0 & $0 \%$ \\
\hline \multicolumn{4}{|c|}{ Benefits that will receive later } \\
\hline & Medicare & 5 & $100 \%$ \\
\hline & Medicaid & 0 & $0 \%$ \\
\hline & SS & 3 & $60 \%$ \\
\hline & SSI & 0 & $0 \%$ \\
\hline & None & 0 & $0 \%$ \\
\hline & Not Applicable & 0 & $0 \%$ \\
\hline & Not Sure & 0 & $0 \%$ \\
\hline \multicolumn{4}{|c|}{ Primary Residence } \\
\hline & USA & 8 & $89 \%$ \\
\hline & Mexico & 1 & $11 \%$ \\
\hline & Both & 0 & $0 \%$ \\
\hline & Other & 0 & $0 \%$ \\
\hline \multicolumn{4}{|c|}{ Family in Mexico } \\
\hline & Yes & 5 & $100 \%$ \\
\hline & No & 0 & $0 \%$ \\
\hline \multicolumn{4}{|c|}{ Where does your family live in Mexico? } \\
\hline & Jalisco & 0 & $0 \%$ \\
\hline & Tamaulipas & 0 & $0 \%$ \\
\hline & Mexico State & 0 & $0 \%$ \\
\hline & Guanajuato & 4 & $100 \%$ \\
\hline & Coahuila & 0 & $0 \%$ \\
\hline & Nuevo Leon & 0 & $0 \%$ \\
\hline & Baja California Sur & 0 & $0 \%$ \\
\hline & Chihuahua & 0 & $0 \%$ \\
\hline & Sinaloa & 0 & $0 \%$ \\
\hline & Navarit & 0 & $0 \%$ \\
\hline & Puebla & 0 & $0 \%$ \\
\hline \multicolumn{4}{|c|}{ Where health care received } \\
\hline & USA & 4 & $100 \%$ \\
\hline & Mexico & 0 & $0 \%$ \\
\hline & Both & 0 & $0 \%$ \\
\hline & Other & 0 & $0 \%$ \\
\hline & None & 0 & $0 \%$ \\
\hline \multicolumn{4}{|c|}{ If not retired, where do you plan to? } \\
\hline & USA & 2 & $33 \%$ \\
\hline & Mexico & 4 & $67 \%$ \\
\hline & Both & 0 & $0 \%$ \\
\hline & Other & 0 & $0 \%$ \\
\hline \multicolumn{4}{|c|}{ Where would you prefer to retire? } \\
\hline & USA & 0 & - \\
\hline & Mexico & 0 & - \\
\hline & Both & 0 & - \\
\hline & Other & 0 & - \\
\hline \multicolumn{4}{|c|}{ What factors influence your reasons to retire? } \\
\hline & Closeness to family & 0 & $0 \%$ \\
\hline & Living cost & 0 & $0 \%$ \\
\hline & Medicare & 7 & $100 \%$ \\
\hline
\end{tabular}




\begin{tabular}{|l|l|l|l|}
\hline \multicolumn{1}{|l|}{ Other } & 0 & $0 \%$ \\
\hline US citizen? & & \\
\hline & USC & 7 & $78 \%$ \\
\hline \multicolumn{2}{|l}{ Not a USC } & 2 & $22 \%$ \\
\hline Spouse a US citizen? & & \\
\hline & Spouse a USC & 5 & $56 \%$ \\
\hline$\quad$ Spouse not a USC & 4 & $44 \%$ \\
\hline Permanent Resident? & & \\
\hline \multicolumn{2}{|l}{ LPR } & 0 & - \\
\hline Not an LPR & 0 & - \\
\hline Spouse a Permanent Resident? & & \\
\hline & Spouse an LPR & 0 & - \\
\hline & Spouse not an LPR & 0 & - \\
\hline
\end{tabular}

Austin surveys were conducted at the Feria Para Aprender, an event open to Austin's Hispanic community with families having children of school and college age. Responses from this event are mostly from females under the age of 49 who are not yet retired and living as either citizens or permanent residents in the United States. Because the group consists of mostly middle-aged adults, three-quarters receive no public health or pension benefits, but approximately 40 percent expect to receive either Medicare or Social Security benefits in the future. The fact that this future expectation is less than half of the population suggests either a poor understanding of public benefits or the dependence upon a family breadwinner who may work less than the ten years required to receive such benefits in the future. Again, most live in the United States but have family in Mexico concentrated in Mexico State, Nuevo Leon, and Puebla. All consume health care services in the United States and prefer to retire in the states as well (Figure 9.4) due to proximity to family members and their expected cost of living (Figure 9.5).

\section{Figure 9.4}

\section{Planned Retirement Location (Austin, Texas)}

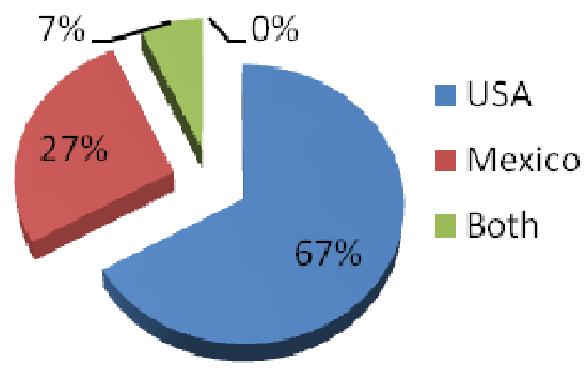


Figure 9.5

Reasons for Retirement Preference

(Austin, Texas)

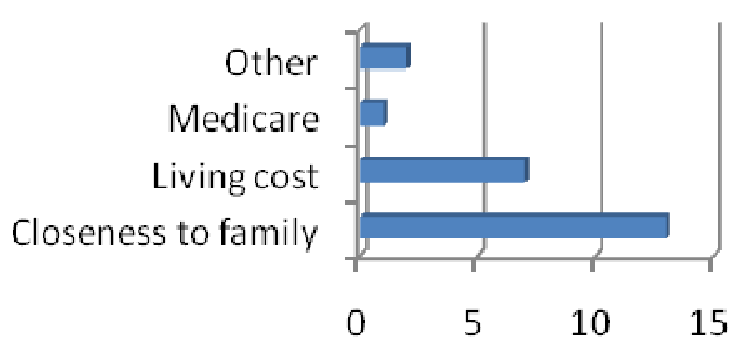

Table 9.3

Austin Survey Responses

\begin{tabular}{|c|c|c|c|}
\hline & & \multicolumn{2}{|c|}{ Austin } \\
\hline & & Individuals & Percent \\
\hline \multicolumn{4}{|l|}{ Age } \\
\hline & $0-49$ & 12 & $75 \%$ \\
\hline & $50-64$ & 4 & $25 \%$ \\
\hline & $65+$ & 0 & $0 \%$ \\
\hline \multicolumn{4}{|c|}{ Gender } \\
\hline & Male & 6 & $38 \%$ \\
\hline & Female & 10 & $63 \%$ \\
\hline \multicolumn{4}{|c|}{ Retirement status } \\
\hline & Retired & 1 & $6 \%$ \\
\hline & Semi-retired & 1 & $6 \%$ \\
\hline & Not retired & 14 & $88 \%$ \\
\hline \multicolumn{4}{|c|}{ Benefits receiving } \\
\hline & Medicare & 1 & $8 \%$ \\
\hline & Medicaid & 1 & $8 \%$ \\
\hline & SS & 2 & $17 \%$ \\
\hline & SSI & 1 & $8 \%$ \\
\hline & None & 9 & $75 \%$ \\
\hline & Not Sure & 0 & $0 \%$ \\
\hline \multicolumn{4}{|c|}{ Benefits that will receive later } \\
\hline & Medicare & 6 & $38 \%$ \\
\hline & Medicaid & 2 & $13 \%$ \\
\hline & SS & 6 & $38 \%$ \\
\hline & SSI & 0 & $0 \%$ \\
\hline & None & 7 & $44 \%$ \\
\hline & Not Applicable & 0 & $0 \%$ \\
\hline & Not Sure & 2 & $13 \%$ \\
\hline
\end{tabular}




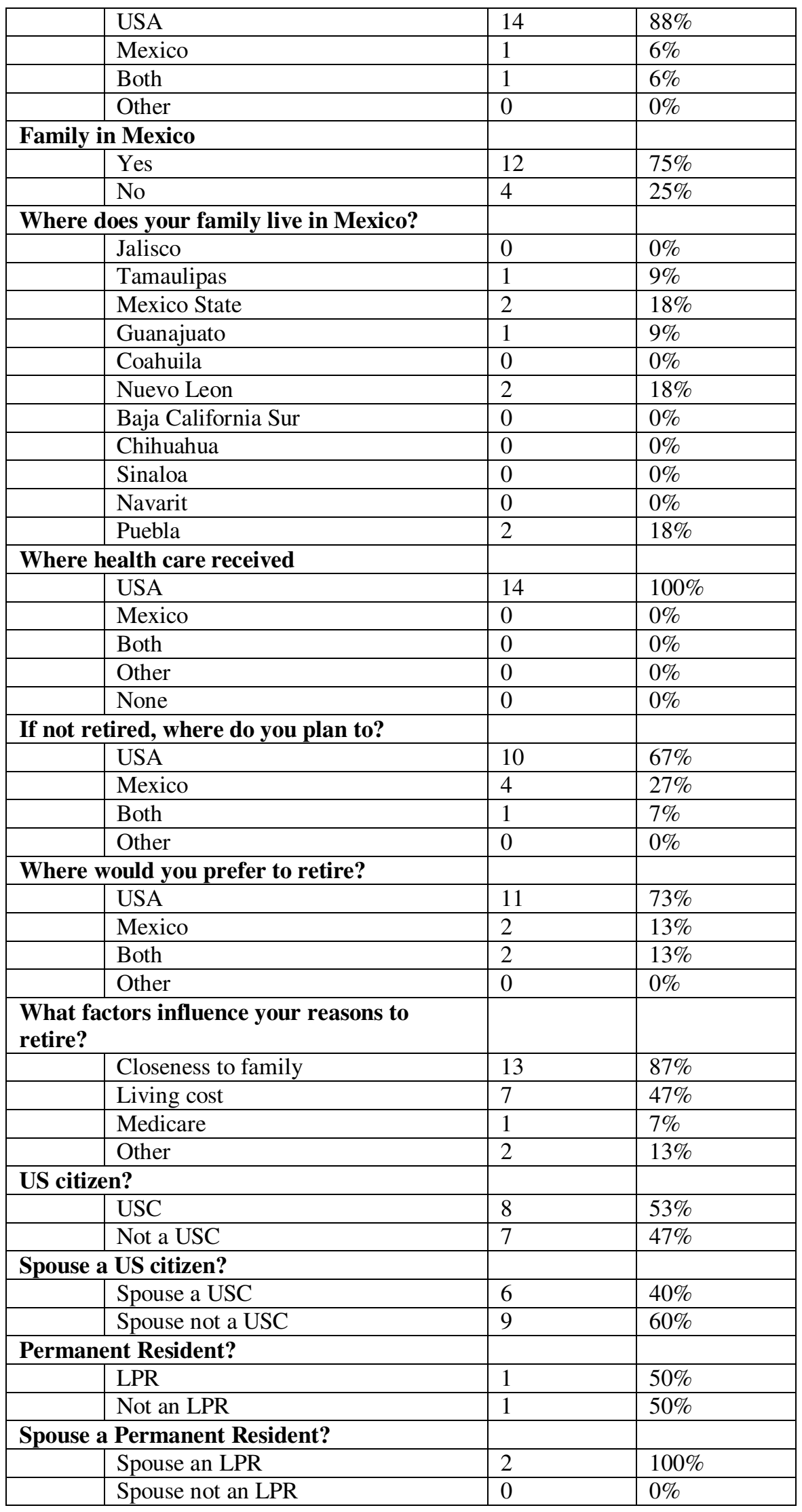


Survey responses obtained at the "Day of the Migrant" celebration in Guanajuato, Mexico, are also mostly from male non-citizens (some U.S. permanent residents) over the age of 65 , with only half of them being retired. They are, however, mostly U.S. permanent residents, with 60 percent currently on Medicare (Figure 9.7), and the remaining 40 percent expecting to receive Medicare benefits and services in the future. Just under half reside primarily in the United States and were visiting home at the time of the survey, while the others reside mostly in Mexico and travel northward to the American states. Most obviously have family in Guanajuato with whom they were visiting during the festival and the remainder of the group has family in the state of Tamaulipas. The entire group was split in half on preference for retirement location and health care, though all were influenced in these decisions by closeness of family and cost of living. Only one-third of respondents were concerned about access to Medicare benefits after retirement.

Figure 9.6

\section{Health Care Location (Guanajuato, Mexico)}

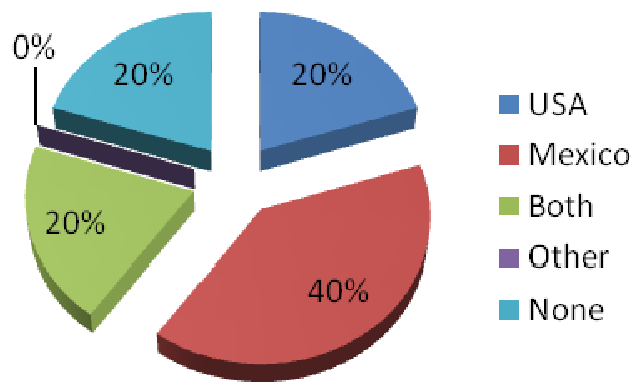

Figure 9.7

People Receiving U.S. Public Benefits (Guanajuato, Mexico)

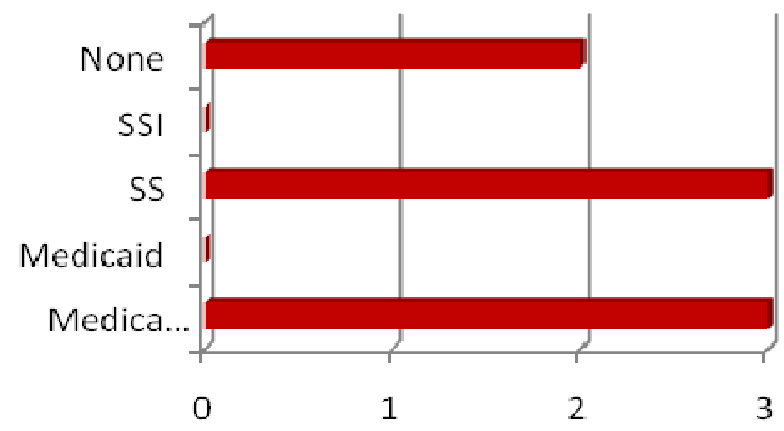


Table 9.4

\section{Guanajuato, Mexico, Survey Responses}

\begin{tabular}{|c|c|c|c|}
\hline & & \multicolumn{2}{|c|}{ Mexico } \\
\hline & & Individuals & Percent \\
\hline \multicolumn{4}{|l|}{ Age } \\
\hline & $0-49$ & 1 & $20 \%$ \\
\hline & $50-64$ & 1 & $20 \%$ \\
\hline & $65+$ & 3 & $60 \%$ \\
\hline \multicolumn{4}{|l|}{ Gender } \\
\hline & Male & 4 & $80 \%$ \\
\hline & Female & 1 & $20 \%$ \\
\hline \multicolumn{4}{|c|}{ Retirement status } \\
\hline & Retired & 3 & $60 \%$ \\
\hline & Semi-retired & 0 & $0 \%$ \\
\hline & Not retired & 2 & $40 \%$ \\
\hline \multicolumn{4}{|c|}{ Benefits receiving } \\
\hline & Medicare & 3 & $60 \%$ \\
\hline & Medicaid & 0 & $0 \%$ \\
\hline & SS & 3 & $60 \%$ \\
\hline & SSI & 0 & $0 \%$ \\
\hline & None & 2 & $40 \%$ \\
\hline & Not Sure & 0 & $0 \%$ \\
\hline \multicolumn{4}{|c|}{ Benefits that will receive later } \\
\hline & Medicare & 2 & $40 \%$ \\
\hline & Medicaid & 0 & $0 \%$ \\
\hline & SS & 1 & $20 \%$ \\
\hline & SSI & 0 & $0 \%$ \\
\hline & None & 0 & $0 \%$ \\
\hline & Not Applicable & 3 & $60 \%$ \\
\hline & Not Sure & 0 & $0 \%$ \\
\hline \multicolumn{4}{|c|}{ Primary Residence } \\
\hline & USA & 2 & $40 \%$ \\
\hline & Mexico & 3 & $60 \%$ \\
\hline & Both & 0 & $0 \%$ \\
\hline & Other & 0 & $0 \%$ \\
\hline \multicolumn{4}{|c|}{ Family in Mexico } \\
\hline & Yes & 5 & $100 \%$ \\
\hline & No & 0 & $0 \%$ \\
\hline \multicolumn{4}{|c|}{ Where does your family live in Mexico? } \\
\hline & Jalisco & 0 & $0 \%$ \\
\hline & Tamaulipas & 1 & $20 \%$ \\
\hline & Mexico State & 0 & $0 \%$ \\
\hline & Guanajuato & 4 & $80 \%$ \\
\hline & Coahuila & 0 & $0 \%$ \\
\hline & Nuevo Leon & 0 & $0 \%$ \\
\hline & Baja California Sur & 0 & $0 \%$ \\
\hline & Chihuahua & 0 & $0 \%$ \\
\hline & Sinaloa & 0 & $0 \%$ \\
\hline & Navarit & 0 & $0 \%$ \\
\hline & Puebla & 0 & $0 \%$ \\
\hline Where he & alth care received & & \\
\hline
\end{tabular}




\begin{tabular}{|c|c|c|c|}
\hline & USA & 1 & $20 \%$ \\
\hline & Mexico & 2 & $40 \%$ \\
\hline & Both & 1 & $20 \%$ \\
\hline & Other & 0 & $0 \%$ \\
\hline & None & 1 & $20 \%$ \\
\hline \multicolumn{4}{|c|}{ If not retired, where do you plan to? } \\
\hline & USA & 1 & $50 \%$ \\
\hline & Mexico & 1 & $50 \%$ \\
\hline & Both & 0 & $0 \%$ \\
\hline & Other & 0 & $0 \%$ \\
\hline \multicolumn{4}{|c|}{ Where would you prefer to retire? } \\
\hline & USA & 2 & $50 \%$ \\
\hline & Mexico & 2 & $50 \%$ \\
\hline & Both & 0 & $0 \%$ \\
\hline & Other & 0 & $0 \%$ \\
\hline \multicolumn{4}{|c|}{$\begin{array}{l}\text { What factors influence your reasons to } \\
\text { retire? }\end{array}$} \\
\hline & Closeness to family & 3 & $60 \%$ \\
\hline & Living cost & 1 & $20 \%$ \\
\hline & Medicare & 0 & $0 \%$ \\
\hline & Other & 3 & $60 \%$ \\
\hline \multicolumn{4}{|c|}{ US citizen? } \\
\hline & USC & 2 & $40 \%$ \\
\hline & Not a USC & 3 & $60 \%$ \\
\hline \multicolumn{4}{|c|}{ Spouse a US citizen? } \\
\hline & Spouse a USC & 0 & $0 \%$ \\
\hline & Spouse not a USC & 5 & $100 \%$ \\
\hline \multicolumn{4}{|c|}{ Permanent Resident? } \\
\hline & LPR & 3 & $100 \%$ \\
\hline & Not an LPR & 0 & $0 \%$ \\
\hline \multicolumn{4}{|c|}{ Spouse a Permanent Resident? } \\
\hline & Spouse an LPR & 1 & $100 \%$ \\
\hline & Spouse not an LPR & 0 & $0 \%$ \\
\hline
\end{tabular}

Despite the risk of a self-selection bias, the final online group of survey participants were much more varied and randomized in responses due to the wider net of access to individuals through the communications technology of the internet. Most respondents are retired male citizens of the United States, but living in locations all around the United States and Mexico. Twenty-five percent are on Medicare, and one-third receives Social Security payments, while nearly half of the group expects to receive these payments later in life. Three quarters of all respondents live primarily in the United States, and the remainder lives in either Mexico or both nations of interest. Two-thirds have family in Mexico, mostly in Jalisco, nearly 40 percent receive health care south of the border, and the majority would prefer to retire to Mexico either full- or part-time (Figure 9.8) in order to be close to family and to enjoy a low cost of living (Figure 9.9). The third of the online population who stated that access to Medicare influences their decision on where to retire currently plan to spend their later years in the United States and possibly Mexico for part of the year rather than full time. 


\section{Figure 9.8 \\ Preferred Retirement Location (Online Survey)}

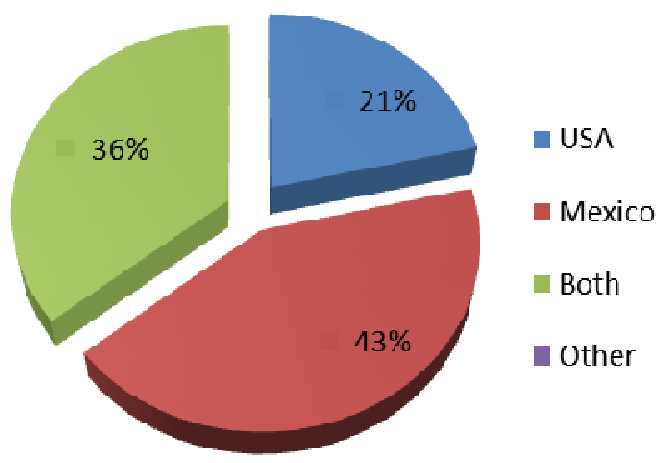

Figure 9.9

Reasons for Retirement Preference (Online Survey)

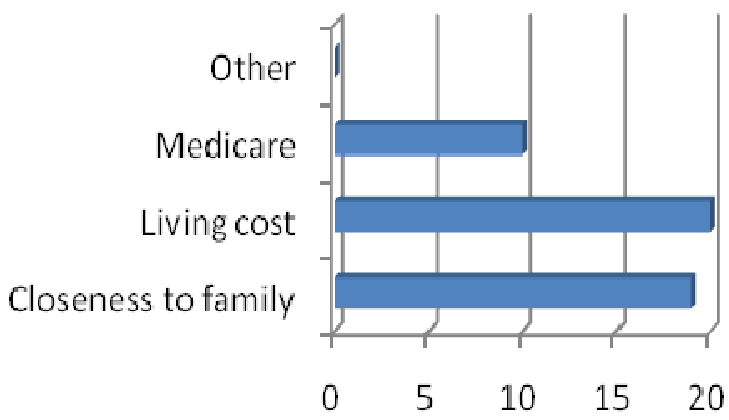

Table 9.5

Online Survey Responses

\begin{tabular}{|l|l|l|l|}
\hline & & \multicolumn{2}{|c|}{ Online } \\
\hline \multicolumn{2}{|l|}{} & Individuals & Percent \\
\hline Age & $0-49$ & & \\
\hline \multicolumn{2}{|l|}{$50-64$} & 15 & $45 \%$ \\
\hline \multicolumn{2}{|l|}{$65+$} & 10 & $30 \%$ \\
\hline Gender & Male & 8 & $24 \%$ \\
\hline \multicolumn{2}{|l|}{ Female } & 26 & $79 \%$ \\
\hline \multicolumn{2}{|l|}{ Retirement status } & 7 & $21 \%$ \\
\hline
\end{tabular}




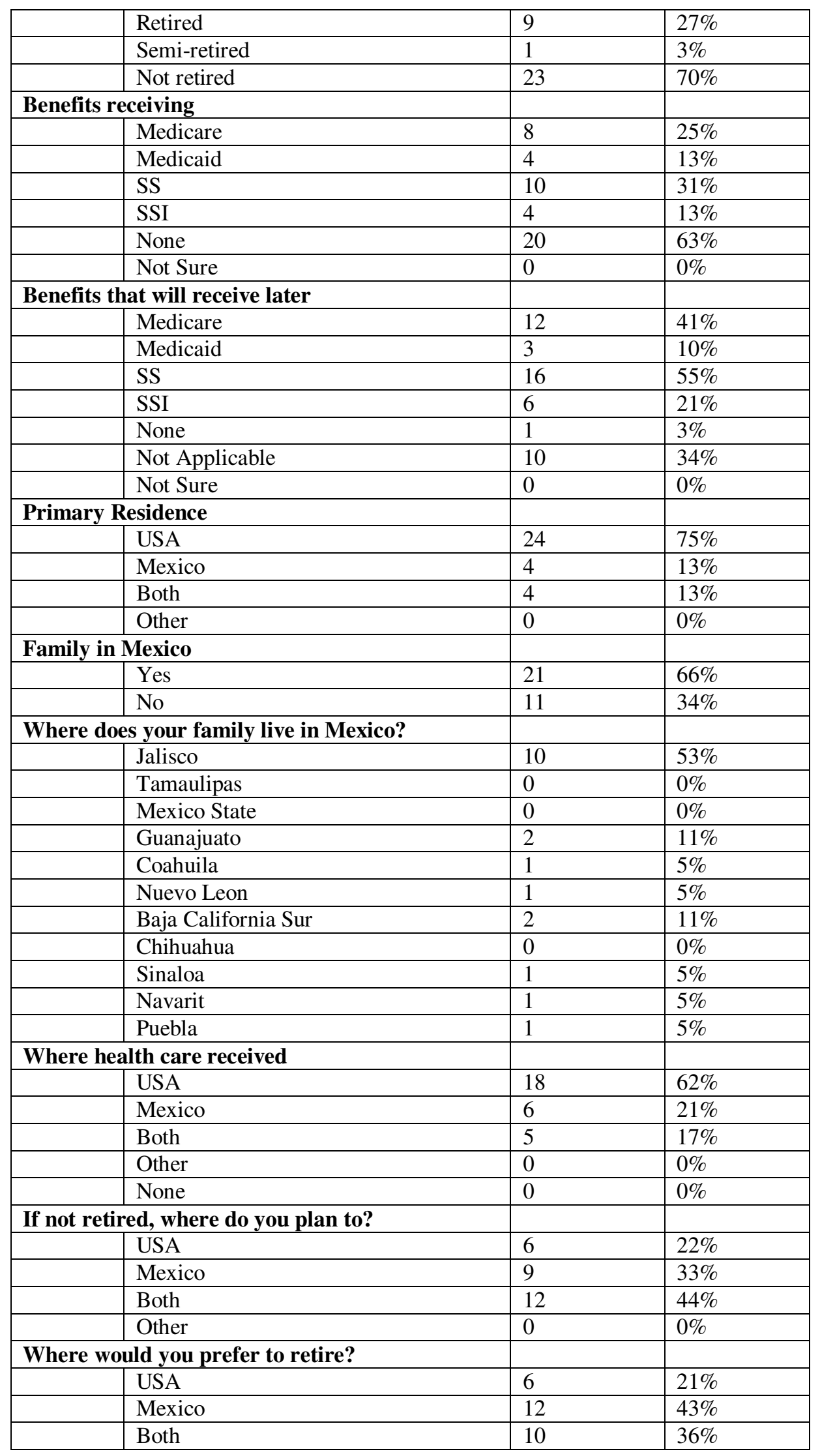




\begin{tabular}{|c|c|c|c|}
\hline & Other & 0 & $0 \%$ \\
\hline \multicolumn{4}{|c|}{ What factors influence your reasons to retire? } \\
\hline & Closeness to family & 19 & $68 \%$ \\
\hline & Living cost & 20 & $71 \%$ \\
\hline & Medicare & 10 & $36 \%$ \\
\hline & Other & 0 & $0 \%$ \\
\hline \multicolumn{4}{|c|}{ US citizen? } \\
\hline & USC & 20 & $69 \%$ \\
\hline & Not a USC & 9 & $31 \%$ \\
\hline \multicolumn{4}{|c|}{ Spouse a US citizen? } \\
\hline & Spouse a USC & 20 & $69 \%$ \\
\hline & Spouse not a USC & 9 & $31 \%$ \\
\hline \multicolumn{4}{|c|}{ Permanent Resident? } \\
\hline & LPR & 19 & $68 \%$ \\
\hline & Not an LPR & 9 & $32 \%$ \\
\hline \multicolumn{4}{|c|}{ Spouse a Permanent Resident? } \\
\hline & Spouse an LPR & 18 & $64 \%$ \\
\hline & Spouse not an LPR & 10 & $36 \%$ \\
\hline
\end{tabular}

The entire population of all persons surveyed is split evenly between males and females, and almost as evenly between full retirees and those who have not yet fully retired. The majority (82 percent) currently resides in the United States and consists of citizens of that country (74 percent). Despite their residence in the U.S. two-thirds respondents have family in Mexico. The Mexican state of origin for most individuals in the entire survey population is Guanajuato, with Jalisco near behind in second place (Figure 9.11).

\section{Figure 9.10 \\ Country of Origin (All)}

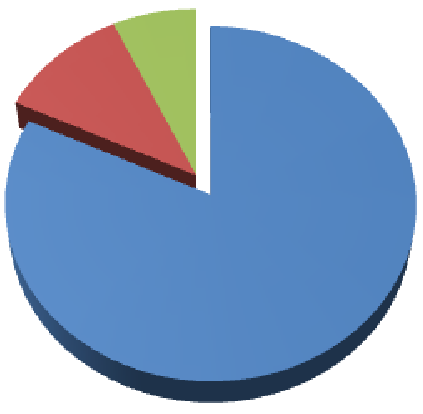


Figure 9.11

Family Location in Mexico (All)

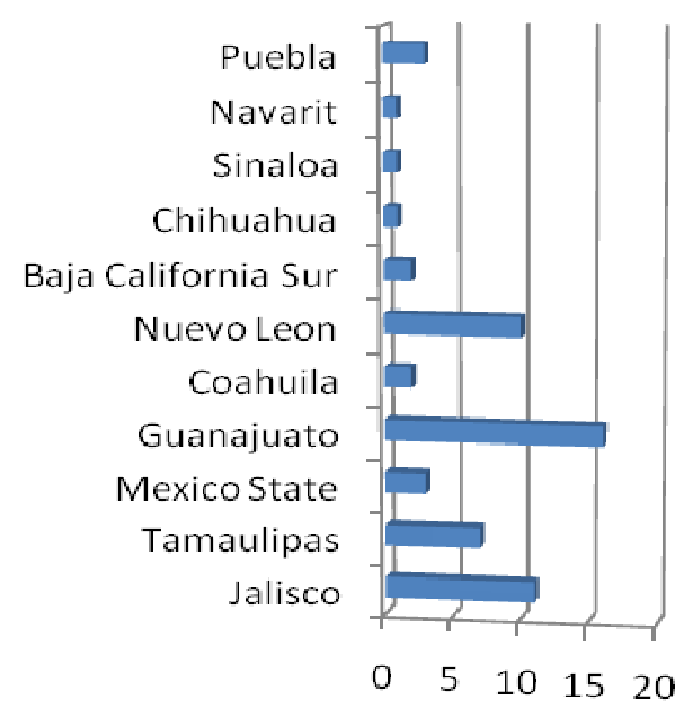

Nearly half of those surveyed currently receive Medicare health care benefits as well, with a third expecting to be on Medicare in the future after reaching age 65. In total, 59 percent of all people surveyed would prefer to retire in Mexico given that they had no constraints whatsoever (Figure 9.12). The number of people actually retired to or planning to retire to the United States in reality, however, is a much smaller 48 percent (Figure 9.13). This shows that despite the fact that one-third of all retires are or will be in Mexico, more Hispanics polled would retire north of the border if they could in order to be close to their families, enjoy a low-cost quality of life, and access Medicare benefits during their retirement years (Figure 9.14).

Figure 9.12

Preferred Retirement Location

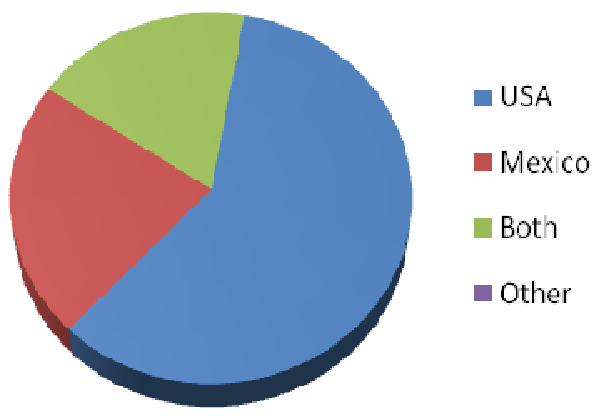


Figure 9.13

\section{Planned Retirement Location}

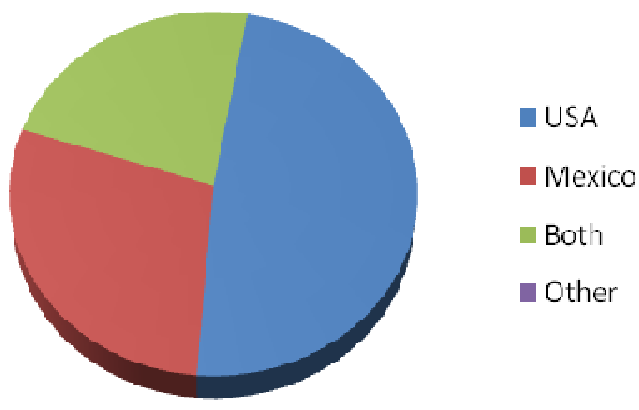

This reality counters the original hypothesis that more individuals would prefer to retire to Mexico under perfect circumstances with portability of Medicare, and it seems to be supported by interviews in which individuals claimed to enjoy life in the United States better, to have sufficient public benefits to make life more affordable, and to live near the many family members that are now residing in the States.

Figure 9.14

Reasons for Retirement Preference (All)

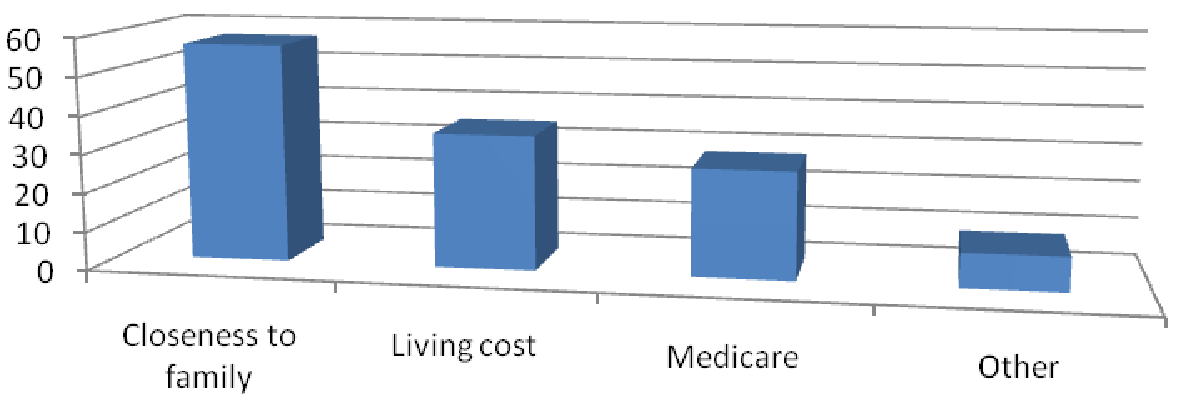




\section{Table 9.6}

\section{All Survey Responses}

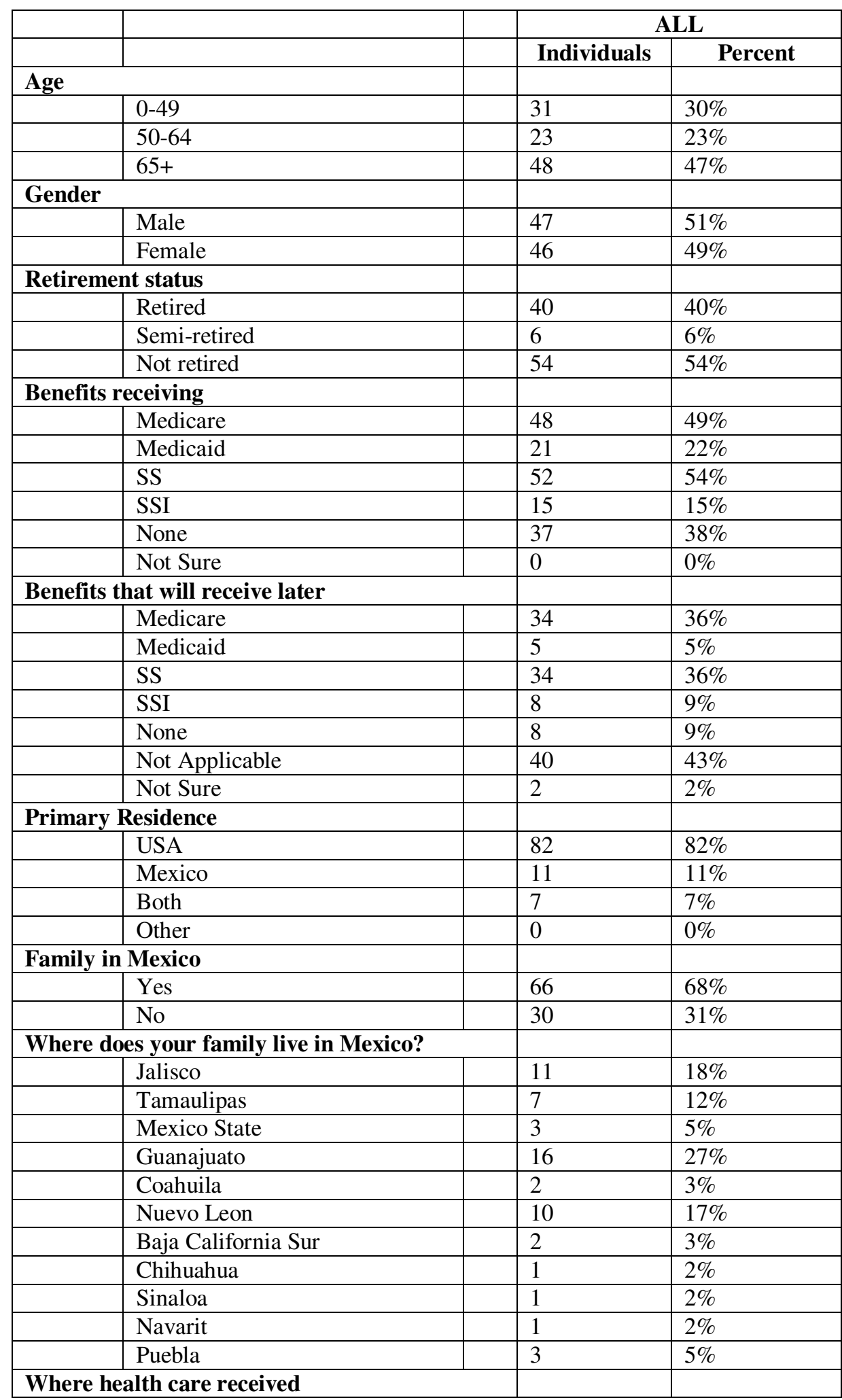




\begin{tabular}{|c|c|c|}
\hline USA & 69 & $78 \%$ \\
\hline Mexico & 9 & $10 \%$ \\
\hline Both & 7 & $8 \%$ \\
\hline Other & 0 & $0 \%$ \\
\hline None & 3 & $3 \%$ \\
\hline \multicolumn{3}{|c|}{ If not retired, where do you plan to? } \\
\hline USA & 32 & $48 \%$ \\
\hline Mexico & 19 & $29 \%$ \\
\hline Both & 15 & $23 \%$ \\
\hline Other & 0 & $0 \%$ \\
\hline \multicolumn{3}{|c|}{ Where would you prefer to retire? } \\
\hline USA & 45 & $59 \%$ \\
\hline Mexico & 17 & $22 \%$ \\
\hline Both & 14 & $18 \%$ \\
\hline Other & 0 & $0 \%$ \\
\hline \multicolumn{3}{|c|}{ What factors influence your reasons to retire? } \\
\hline Closeness to family & 57 & $66 \%$ \\
\hline Living cost & 35 & $41 \%$ \\
\hline Medicare & 28 & $33 \%$ \\
\hline Other & 9 & $10 \%$ \\
\hline \multicolumn{3}{|l|}{ US citizen? } \\
\hline USC & 67 & $74 \%$ \\
\hline Not a USC & 23 & $26 \%$ \\
\hline \multicolumn{3}{|l|}{ Spouse a US citizen? } \\
\hline Spouse a USC & 46 & $52 \%$ \\
\hline Spouse not a USC & 43 & $48 \%$ \\
\hline \multicolumn{3}{|l|}{ Permanent Resident? } \\
\hline LPR & 25 & $71 \%$ \\
\hline Not an LPR & 10 & $29 \%$ \\
\hline \multicolumn{3}{|l|}{ Spouse a Permanent Resident? } \\
\hline Spouse an LPR & 22 & $69 \%$ \\
\hline Spouse not an LPR & 10 & $31 \%$ \\
\hline
\end{tabular}


(this page intentionally left blank) 


\title{
Chapter 10. Personal Interviews: The Impact of Medicare Portability on Individuals
}

\author{
by Alani Mayela Mundie
}

In an effort to gather more detailed accounts of what effects the lack of Medicare coverage in Mexico has on Mexican-born U.S. citizens or permanent residents, we conducted various personal interviews, in both the U.S. and Mexico, to help fully grasp the impact of Medicare portability on these individuals. The interviews below are from individuals of varied backgrounds, experiences, and income levels. Although the availability of Medicare benefits did not heavily influence the location of retirement (in either the U.S. or Mexico) for the individuals interviewed, the impact that the lack of coverage had on those retired in Mexico was significant.

\section{Guanajuato, Mexico}

We began our surveys and interviews of the Mexican-born U.S. citizen or permanent resident population that has chosen to retire to Mexico, by traveling to the Mexican state of Guanajuato. Upon our arrival in Silao, Guanajuato, we were met by Señora Silvia Ramirez, the California-based representative for an organization called Casa Guanajuato. This organization helps individuals from the state of Guanajuato that migrate to the U.S. with any legal, immigration, or assimilation issues on both sides of the border. Because of her role as the California representative for Casa Guanajuato, Señora Ramirez spends half of the year in San Diego and the other half in Guanajuato.

Sra. Ramirez led us first to a city outside of Leon, Guanajuato, called San Francisco del Rincon. The industrial town of San Francisco del Rincon, Mexico, is comprised of approximately 57,000 inhabitants and growing. Known for its plentiful production of tennis shoes and hats (sombreros), San Francisco del Rincon experiences a lot of migration from the states of Oaxaca and Guerrero, as the opportunities the factories provide are numerous in comparison to any opportunities available in the rural villages that populate Oaxaca and Guerrero.

Outside of San Francisco del Rincon is the smaller and poorer rural suburb of El Maguey, with a population of approximately 8,000 inhabitants, the majority of whom are farmers. Being a poor, agricultural town, migration to the U.S. is very common among the citizens of El Maguey. The majority of those migrating tend to migrate to either Sacramento or Oakland, California, Reno, Nevada, and a few to Chicago, Illinois.

Upon our arrival in El Maguey, we were introduced to the unofficial community leader, Señora Graciela Segura Vasquez. Sra. Vasquez led us to one of El Maguey's town meeting centers where we met with a large group of Braceros interested in learning how to collect the benefits owed to them from their years of work in the U.S. as farmers under the Mexican and American government-sponsored Bracero program of 1942. The Bracero program allowed for the temporary importation of contract laborers from 
Mexico to the United States but left many of the Braceros without the full benefits promised to them. According to Sra. Vasquez, the majority of Braceros are not citizens or residents of the U.S. and receive all of their benefits from Mexico. Sra. Vasquez, who knows everyone in town - from their family lineages down to their most recent gossipestimates that only about 15-20 individuals in El Maguey are eligible to receive Medicare.

Sra. Vasquez's father was a U.S. citizen and brought her entire family to the U.S. when she was a child. As a result of her family's time in the U.S., her mother became a U.S. permanent resident in California. After a number of years in California, her family decided to return to El Maguey to re-establish their roots. In her elderly years, Sra. Vasquez's mother became ill and was in need of open-heart surgery. She decided to return to the U.S. to receive her open-heart surgery because, in her opinion, the American health care system is much better than in Mexico and her Medicare benefits would cover the costly procedure. Because of her decision to have her operation in the U.S., Sra. Vasquez chose to move back to California with her mother so that she could assist her during her recovery and find a temporary job in the U.S. to help with any additional incurred costs not covered by Medicare. After her successful surgery in the U.S., Sra. Vasquez and her mother moved back to El Maguey.

Shortly thereafter, Sra. Vasquez's father was diagnosed with cancer. In order to receive chemotherapy treatments covered under Medicare, he had to begin traveling back and forth from the U.S. to Mexico with the accompaniment of one of his children. The costs incurred by traveling so often were significant for the Vasquez family, so the means of travel sometimes consisted of 24-hour bus rides back and forth across the border-a trip that was wearisome on an elderly man undergoing chemo-in order to cut down on expenses. Because chemo depletes cell growth, it also depletes the growth of white blood cells that are crucial to a defensive immune system. With a chemo-debilitated immune system, travel and being in large crowds can be very dangerous to cancer patients as exposure to foreign germs can lead to infections that their bodies can't fight. The stress of travel, coupled with its incurred costs and a weakened immune system, made the condition of Sra. Vasquez's father an even more difficult one. He would get so sick from his chemo treatments in the U.S. that he eventually chose to stop traveling across the border to receive them, and passed away in Mexico.

To Sra. Vasquez, there is no doubt in her mind that her father would have lived longer had he been given the opportunity to receive his treatments under Medicare near home where his family could watch over him and help him with the aftercare of chemo treatments without having to undergo such lengthy travel. There is no way to measure for how much longer her father would have lived had he not had to receive treatment in the U.S. solely so that he and his family could afford it; but there is little doubt that had he had access to medical coverage in Mexico, his remaining time would have been more comfortable.

In another interview in El Maguey, we spoke with Señor José Hernandez Muriilo—a 79year-old native of San Francisco del Rincón. In 1949, he went to work in the United 
States under the Bracero program for four years before moving to Sacramento where he continued to work in agriculture. He spent ten years in the United States as a U.S. permanent resident and received Social Security and Medicaid. However, he returned to Mexico two years ago because he couldn't afford the cost of living in the U.S. Although he has five children living in the U.S. and only one in Mexico, he still chose to retire in Mexico because of its affordability. As for his medical costs, he has to pay them out of pocket and would be very interested if Medicare could reimburse his costs.

According to Sra. Ramirez, our tour guide into San Francisco del Rincon and El Maguey, the majority of the people that are eligible for Medicare stay in the U.S. for a couple of months to receive their treatments and then return to Mexico. Sra. Ramirez's father, Señor Manuel Ramirez Segura, is a 73-year-old with U.S. residency that has chosen to retire in Mexico. He opened a bank account in Mexico City to receive his pension benefits in Mexico; however, according to Sra. Ramirez, in order to for him to receive his U.S. pension benefits in Mexico, there is a hefty bank fee incurred before he can receive them.

Our next stop was the small town of Chichimiquillas, a very rural pueblito outside of Silao. There are approximately 4,000 people residing in and around Chichimiquillas, roughly 10 percent of who are U.S. citizens or permanent residents. A large portion of this already small population has migrated to the U.S. Of the remaining residents, we were fortunate enough to interview three of the elderly citizens that had spent time in the U.S. Of them, one was a U.S. citizen, one was a permanent resident, and another had two more years to retire and was positive that he would be retiring to Mexico. Only one of them receives Social Security.

The gentleman receiving Social Security prefers not to receive his Medicare benefits in the U.S. Whenever he gets sick he chooses to travel to Tijuana for treatment. Even though his treatment would be free in the U.S. under Medicare, he prefers to continue to receive his healthcare in Mexico because, according to him, the doctors and nurses that treat him in the U.S. never speak Spanish and the American medical system is far too complicated for him. For example, he had a mole that needed to be removed and in the U.S., it necessitated a referral from one doctor to another before he could ever get the issue addressed. He felt that the entire undertaking of getting treatment in the U.S. is just too difficult for him. He said that it would be incredibly beneficial to him if he could receive Medicare coverage in Mexico because he could then continue to get the medical attention he prefers without having to incur the costs.

In all three cases, none could afford to continue living in the U.S. so they returned (or planned to return) to Mexico and moved in with their families where they don't have to pay rent. All three agreed that receiving Medicare benefits in Mexico would be of great benefit to them and their families.

The last visit during our travel in Guanajuato was the even smaller town of Bajillo de la Guadalupe, population of 100 - approximately 56 of whom have migrated. The staggering number of how many have migrated is a sign of the limited opportunities these 
small rural towns have to offer and the pressure of having to migrate north in search of work.

\section{Puerto Vallarta, Mexico}

In response to a survey conducted by the LBJ School of Public Affairs in 2007, one individual recounted the experience that the lack of medical reimbursement had on her grandfather who was in need of emergency care while he was in Puerto Vallarta:

"My grandfather lives in Puerto Vallarta, Mexico. He is 84 years old and in perfect health. In January 2007, he fell and hit his head while cleaning the floor of his home and was found a few days later in his room. He was rushed to the hospital where doctors determined that he was bleeding from the outer part of his brain and the only way he would live is if they performed surgery to drain the blood that was causing the pressure in his brain.

Doctors said they needed $\$ 12,000$ dollars before they would start the emergency surgery. They contacted me to let me know about the situation and I collected the surgery fee and wired it to Puerto Vallarta. My grandfather was fine the first day after surgery, yet soon fell unconscious again. My uncle called and told me that grandpa was not doing well and that the doctors wanted to open up his skull to find out what the problem was. This surgery was going to cost more than the first one.

I begged my uncle to bring him back to the U.S. because he had benefits and better care here in the U.S. However, my uncle said he couldn't do this because my grandfather was in critical condition and almost ready to pass. I decided that I would go get him and bring him back to the states. I purchased our tickets and I got on the first plane out and flew all night to get to Puerto Vallarta. I rushed to the hospital. My grandfather looked like a corpse and had tubes coming out of his head with surgical gloves at each end where the blood would drain into. He had no machinery monitoring his condition at all. I argued with the doctors, nurses, and paramedics. They did not want me to take him out in his condition and said that the airlines would not accept someone in his condition on the plane. I insisted that I was going to do it anyway; I didn't care what they had to say after seeing the condition he was in. I knew that if I didn't try he would die anyway, so I had the nurses remove the IV and empty out his catheter. I taped and wrapped his catheter around his leg, I shaved him, and got him dressed and left.

When we got to the airport, I put him in a wheel chair and wrapped a small blanket around his neck to prop his head up and put a baseball cap on his head to cover up the wounds. To get my grandfather through immigration, I shook him very hard to wake him up and told him to open his eyes and he did. That lasted long enough for him to get through immigration. As the plane started to move I started crying because I was so relieved to be on the way to the U.S. with my grandfather. Even though I was happy to be on our way I was still very scared. I started panicking when I noticed that my grandfather was heating up and that I couldn't do anything for him. Every so often the stewardess would stop and ask what was wrong with my grandpa, and I would say that I sedated him because he was afraid of flying and he had Alzheimer's disease. 
Approximately 30 minutes before our arrival to San Francisco, I beeped the stewardess and told her to please ask the pilot to have an ambulance waiting for us when we arrived. As soon as we landed paramedics and firemen rushed my grandpa to the hospital. The paramedics told me that if the plane had been in the air one more hour my grandpa would have died.

As soon as we arrived at the hospital, the doctors started treating him immediately. The neurologist told me that he had never seen anything like the procedure that was done to my grandfather's head and he was concerned and that he would get an infection (meningitis). The doctors were not concerned about the bleeding in my grandpa's brain, which was the original problem, but about the procedure done in Mexico.

All in all, my grandpa stayed at Stanford Hospital for 11 days, fought meningitis, and did not need any type of brain surgery, but was cured with medication only. He is perfectly fine mentally and owes no money to the hospital, thanks to Medicare. He is now back in Puerto Vallarta to finish living the rest of his life there. If he had his Medicare benefits in Mexico, I could have taken him to another hospital in any part of Mexico (Mexico City or Guadalajara) instead of having to go through hell to get him back to the U.S. to save his life. I wouldn't want anybody else having to go through what I went through to save a loved one."

\section{Chihuahua, Mexico}

Lilia Calderon and Rafael Fisher Calderon, both former residents of Cuidad Juarez, are/were dual-citizens of the U.S. and Mexico. Part owners of Azteca Films and Producciones Calderon, the former film producers of numerous movies during the Golden Era of films in Mexico and the previous owners of the majority of movie theaters throughout Mexico, Lilia and Rafael Calderon, parents of eight children, chose to make Cuidad Juarez, Chihuahua, Mexico, their home in 1975. A city of over a million inhabitants bordering El Paso, Texas, separated only by the trickling of an over-dammed Rio Grande, Cuidad Juarez was recently named the "Murder Capital of the World" by the Washington Post due to the increasing violence that feuding drug cartels have imposed upon the city.

In 2009, Rafael was diagnosed with myelo-dysplastic syndrome, a bone marrow disorder that causes the body to not produce enough red blood cells to allow it to function properly. Added to this diagnosis was a progressive case of dementia. With the aid of a "fast-pass," a pass that aids individuals to cross the border faster after paying a substantial fee, Rafael was able to cross the border with the help of his children (also dual-citizens residing in both El Paso and Juarez) in order for him to receive weekly blood transfusions. Even individuals with fast-passes sometimes have to wait up to an hour to cross the border, a wait that can seem like days with a dementia patient. After five months of battling this disease coupled with multiple border crossings to seek treatment, Rafael became too weak to continue to cross the border. In addition to the burden of border crossing for a sick patient, daily travel in Juarez was becoming increasingly dangerous due to random shootings, car-jackings, and kidnappings. 
Therefore, one of his daughters, Clarissa Yanar, a resident of Juarez, found him a hospital in Juarez to help with the desperately needed blood transfusions until he passed away at his home in October 2009. Because of the lack of Medicare coverage in Juarez, the Mexican hospital costs incurred were paid in cash by Lilia with no reimbursement. Rafael Calderon now rests in peace in Cuidad Juarez, a city that the remainder of his family, including his wife Lilia, had to flee because of violence. Lilia was Rafael's dependent under Medicare and is still receiving coverage.

\section{Dallas, Texas}

La Voz del Anciano is a non-profit organization in Dallas, Texas whose primary focus is serving the needs of the Latino elderly population of more than approximately 50,000 living in and around the Dallas Metroplex. In an interview with a representative from La Voz del Anciano, we learned of the difficulties this individual was experiencing with the lack of cross-border Medicare coverage on behalf of her mother. Her parents migrated to the U.S. from San Luis Potosí where they spent many years working. Both her parents received Social Security benefits but when her father died, her mother returned to San Luis Potosí. In an effort to continue receiving her Social Security benefits, her mother has to take a bus back to Laredo once a month to have her Social Security form stamped as proof that she is still in the country. Now that her mother is becoming less mobile, our interviewee expressed worries over her mother making the long trek every month.

The Brady Center is a Catholic charity located in Dallas, Texas. There we interviewed an 86-year-old gentleman from Frenillo, Zacatecas, who became part of the Brady Center in 1991. He entered the United States in 1960 and is currently a U.S. permanent resident. He worked in agriculture for eight years but lacked the two additional years needed in order to qualify for Medicare. However, an exception was made on his behalf so that he could begin to receive benefits. He has received Medicare and Medicaid since the 1990s and has also participated in the "Plan Parkland Plus" for over five years. This is a plan with Parkland Hospital in Dallas, which allows him the opportunity to receive his medication for "two pesos."

Of his ten children, eight live in the U.S. including one with whom he lives. The other two live in live in Zacatecas, where he goes to visit every two years for two-week periods. Although he has houses in Mexico where his daughters live, he wants to remain in the U.S. because of the help the government offers with food and medicine. 


\section{Notes}

${ }^{1}$ Lyndon B. Johnson School of Public Affairs, Medicare in Mexico: Innovating for Fairness and Cost Savings, Policy Research Project Report Series, no. 156 (The University of Texas at Austin: Austin, Tex., 2007), pp. 152-153. 
(this page intentionally left blank) 


\title{
Appendix A. Example of Congressional Proposals
}

\author{
by Alani Mayela Mundie
}

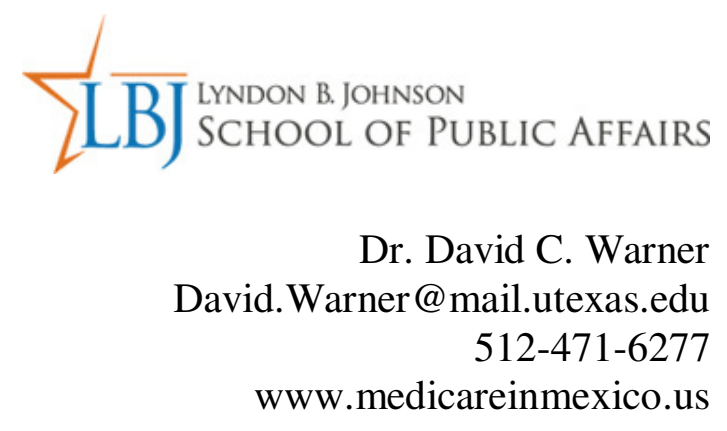

For the consideration of:

Congresswoman Eddie Bernice Johnson

30 $^{\text {th }}$ Congressional District

\section{Medicare Portability: Extending Medicare to \\ Eligible Beneficiaries in Mexico}

\author{
A Policy Research Project
}

\section{Background}

Over the past decade, an increasing number of U.S. citizens and permanent residents, both native and foreign-born, have been moving to Mexico to retire. Communities of American retirees are rapidly developing across Mexico and Mexicans who have spent a substantial amount of time working in the U.S. are often returning to their communities of origin.

Medicare rarely reimburses for health care received outside of the U.S.; therefore, many beneficiaries who retire to Mexico must travel back to the U.S. to receive medical attention. Without access to Medicare benefits, these retirees are more vulnerable to the potentially devastating financial consequences of inadequate health insurance coverage, especially in the cases of emergency medical care. Although some beneficiaries who have Medicare through an HMO or a Medigap supplemental insurance plan may be covered through the first 60 days that they are out of the country, those who choose to retire to Mexico and live outside of the U.S. for more than half of the year or who do not have these supplemental plans are not eligible for such coverage.

As more Americans retire to Mexico, government-sponsored health care coverage for U.S. retirees should examine options to adapt to the needs of its diverse beneficiaries. 
However, The Center for Medicare and Medicaid Services - U.S. Department of Health and Human Services is reluctant to conduct pilot projects to test and measure the effect of potential program changes internationally without Congressional approval.

\section{Research Project}

Directed by Dr. David C. Warner, a group of researchers from the LBJ School of Public Affairs at the University of Texas at Austin have conducted an investigation into whether Mexican-born/U.S.-born citizens and permanent residents traveling or retiring to Mexico would benefit from receiving Medicare coverage while in Mexico, especially for emergency medical care services.

Research results from surveys (in both English/Spanish) that were distributed to various Mexican-born/U.S.-born, Medicare-eligible populations via online methods and in-person distributions throughout Texas and in Guanajuato, Mexico, showed that the extension of Medicare coverage into Mexico would be significantly beneficial, especially for emergency services.

\section{Benefits for District 30*}

The total number of Mexican-born residents in the 30th Congressional District is approximately 124,763 , nearly 4,000 of whom are 65 or older. ${ }^{1}$ As evidenced by the map below, the number of Mexican-born constituents in the 30th Congressional District that would have the option to benefit from the extension of Medicare coverage into Mexico is significant.

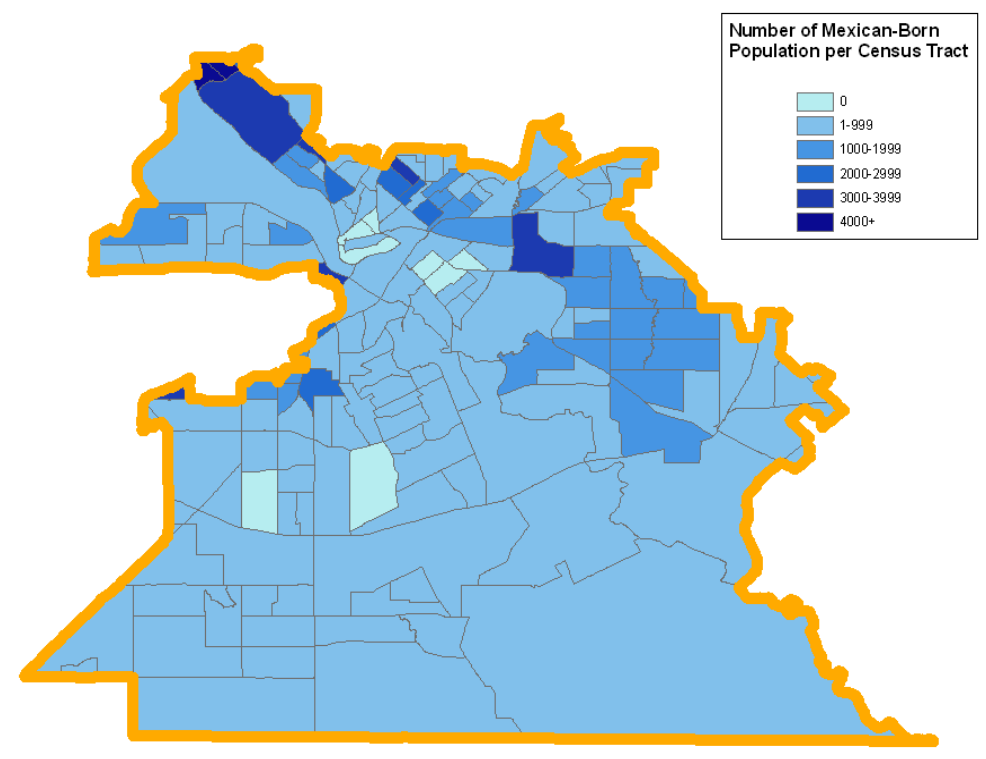

${ }^{1}$ U.S. Census Bureau, "Census 2000 Summary File 4" database. Online. Available: http://factfinder.census.gov. Accessed March 4, 2010. 
With the extension of Medicare portability into Mexico, constituents would be allowed the opportunity to retire to their country of origin or travel home to visit family without facing devastating financial burdens should they need to seek medical attention or emergency medical care while outside of the U.S. Not only does the extension of Medicare coverage into Mexico benefit the Mexican-born constituency that is eligible for Medicare, but also the thousands of U.S.-born citizens that choose to retire to Mexico.

* A congressional proposal was drafted for nine members of Congress in Texas and California, who each represent a significant number of residents born in Mexico. Following are the corresponding data and maps for each district.

\section{$\underline{T E X A S}$}

\section{Congressman Pete Sessions}

\section{2nd Congressional District}

\section{Benefits for District 32}

The total number of Mexican-born residents in the 32nd Congressional District is approximately 121,000 , nearly 4,000 of whom are 65 or older.

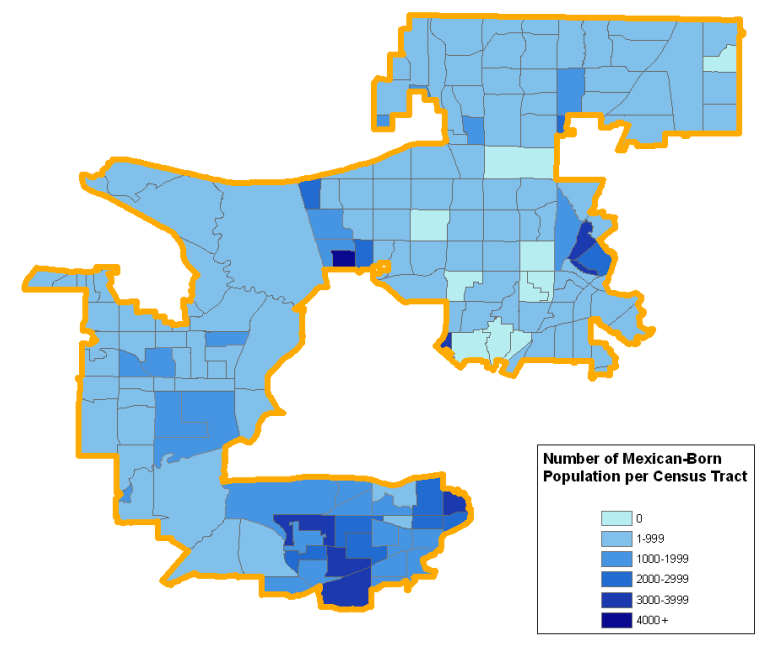

\section{Congresswoman Kay Granger 12th Congressional District}

\section{Benefits for District 12}

The total number of Mexican-born residents in the 12th Congressional District is approximately 78,000 , nearly 3,000 of whom are 65 or older. 


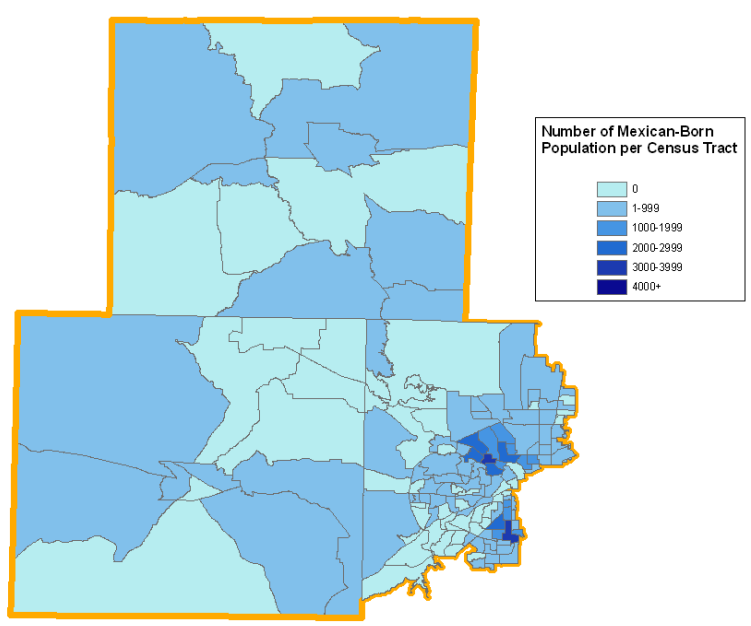

\section{CALIFORNIA}

Congresswoman Judy Chu 32nd Congressional District

\section{Benefits for District 32}

The total number of Mexican-born residents in the 32nd Congressional District is approximately 136,843, nearly 14,642 of whom are 65 or older.

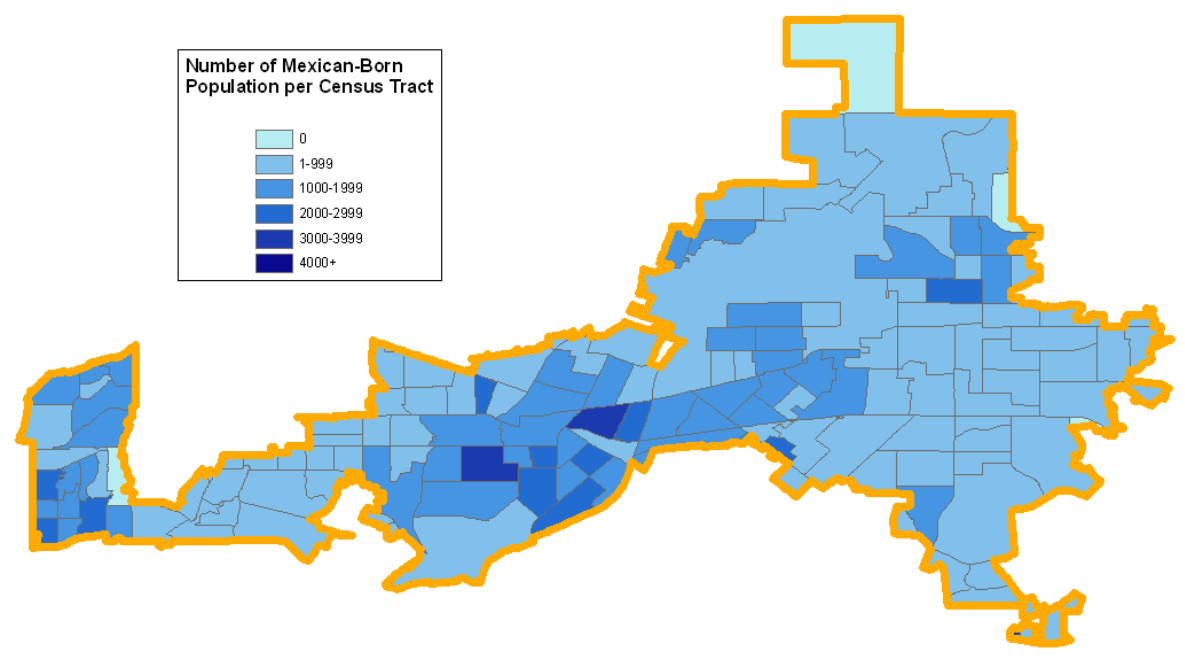

Congressman Joe Baca

43rd Congressional District

Benefits for District 43 
The total number of Mexican-born residents in the 43rd Congressional District is approximately 160,845 , nearly 9,000 of whom are 65 or older.

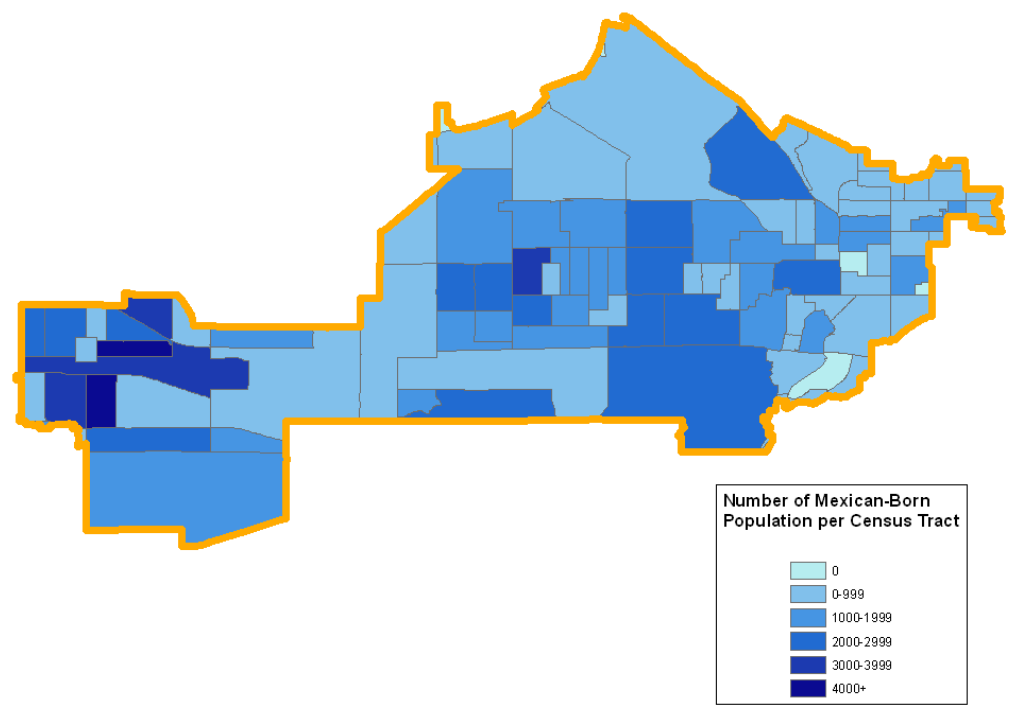

\section{Congresswoman Loretta Sanchez}

\section{7th Congressional District}

\section{Benefits for District 47}

The total number of Mexican-born residents in the 47th Congressional District is approximately 210,023 , nearly 10,000 of whom are 65 or older.

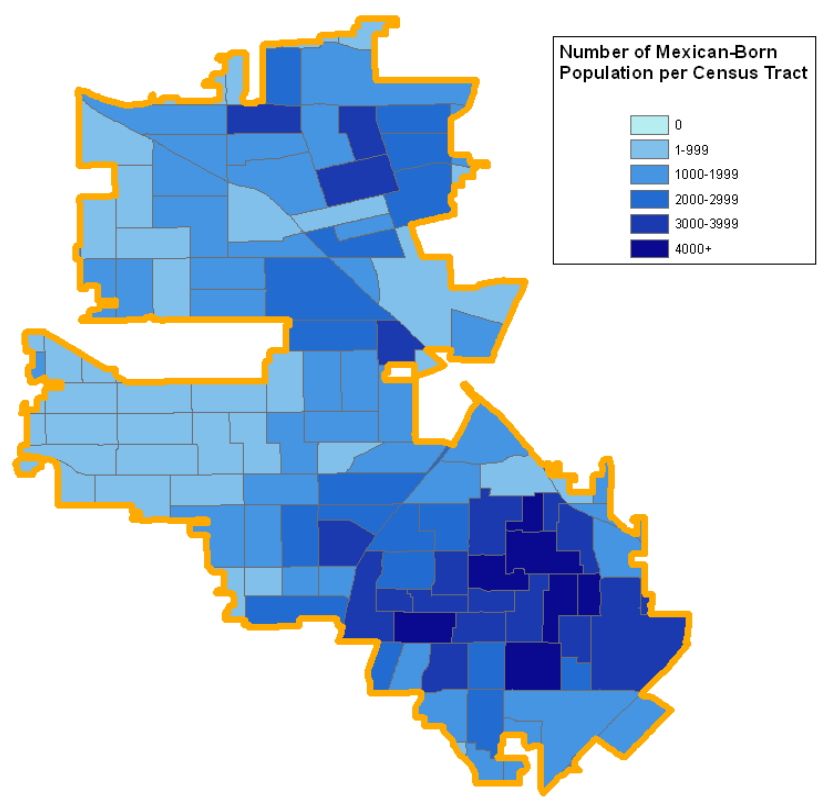




\section{Congresswoman Linda Sanchez \\ 39th Congressional District}

\section{Benefits for District 39}

The total number of Mexican-born residents in the 39th Congressional District is approximately 142,723, nearly 11,000 of whom are 65 or older.

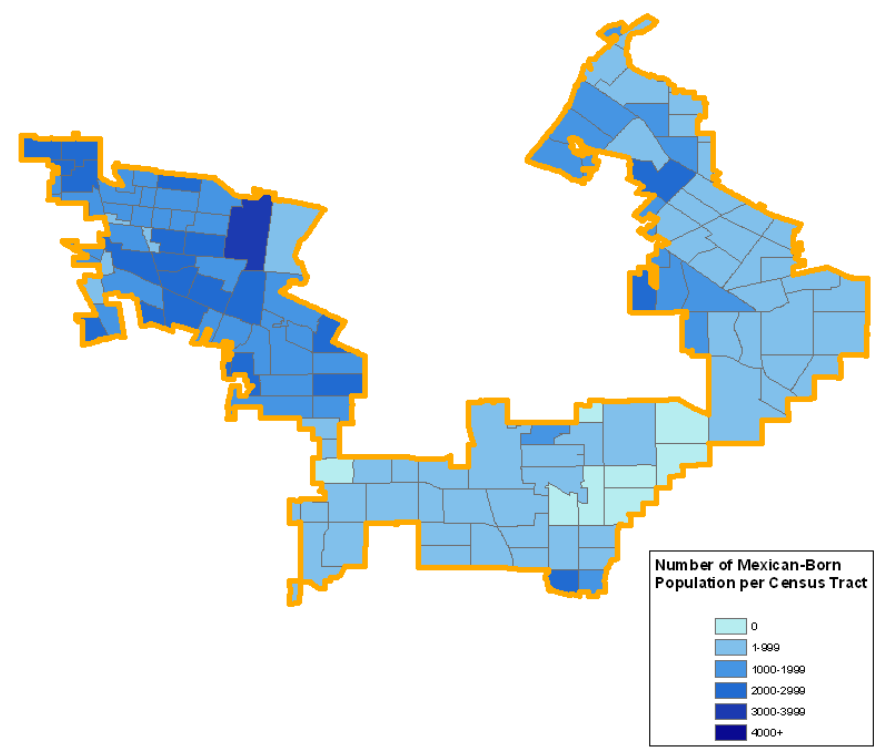

\section{Congressman Xavier Becerra}

31st Congressional District

\section{Benefits for District 31}

The total number of Mexican-born residents in the 31st Congressional District is approximately 142,866, nearly 11,500 of whom are 65 or older.

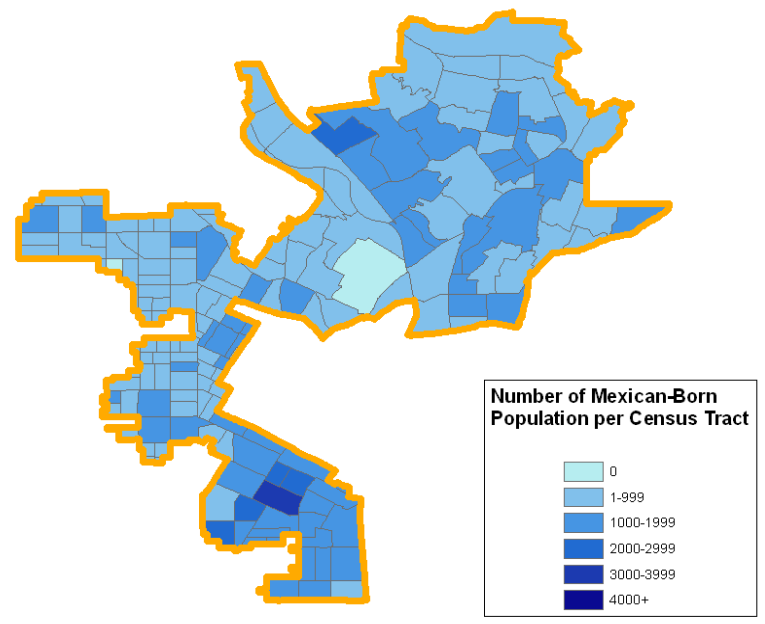




\section{Congresswoman Lucille Roybal-Allard}

\section{4th Congressional District}

\section{Benefits for District 34}

The total number of Mexican-born residents in the 34th Congressional District is approximately 195,084, nearly 16,000 of whom are 65 or older.

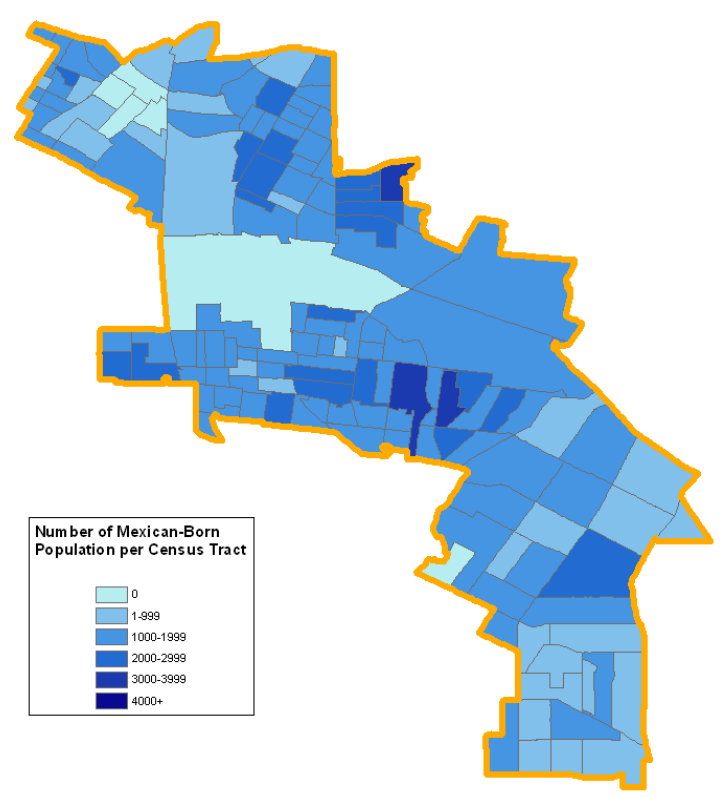




\section{Notes}

${ }^{1}$ U.S. Census Bureau, "2006-2008 American Community Survey, 3-year estimates" database. Online. Available: http://factfinder.census.gov/servlet/DatasetMainPageServlet?_program=ACS\&_submenuId= datasets_2\&_lang=en\&_ts=. Accessed: February 20, 2010. 


\section{Appendix B. Medicare in Mexico Survey}

Dear Survey Participant:

Thank you for participating in this confidential survey. The purpose of the survey is to see if it would be helpful for Medicare to pay for medical services provided to people when they are living in Mexico. Please do not write your name anywhere in the survey so that your identity will remain anonymous.

If you would please take this survey online, look up the survey at the URL:

http://www.surveymonkey.com/s/medicareenglish

If you want to mail this form in, please send it to:

Dr. David Warner

LBJ School of Public Affairs

Drawer Y, The University of Texas at Austin

Austin, TX 78713

Thank you very much for your time and cooperation.

Best regards,

Graduate Student Research Team

LBJ School of Public Affairs

University of Texas at Austin

Austin, Texas

\section{Medicare in Mexico Survey}

1. Your age (please circle one):
○ 0-49
○ 50-64
○ 65 or older

2. Your gender:
- Male
○ Female

3. Your retirement status:

○ Retired

- Semi-retired

o Not retired 
4. Which of the following benefits are you currently receiving? (please choose all that apply)

\begin{tabular}{|c|c|c|c|}
\hline Medicare & Yes & No & Not sure \\
\hline Medicaid & Yes & No & Not sure \\
\hline U.S. Social Security & Yes & No & Not sure \\
\hline Supplemental Security Income & Yes & No & Not sure \\
\hline
\end{tabular}

5. ONLY for those younger than 62:

Which of the following benefits do you expect to receive at age 65 or older?

\begin{tabular}{|c|c|c|c|}
\hline Medicare & Yes & No & Not sure \\
\hline Medicaid & Yes & No & Not sure \\
\hline U.S. Social Security & Yes & No & Not sure \\
\hline Supplemental Security Income & Yes & No & Not sure \\
\hline
\end{tabular}

6. Where is your primary residence? (please choose only one)

○ U.S.

○ Mexico

- Both in the U.S. and Mexico

- Another country

7. Do you have any family in Mexico?

$\begin{array}{ll}\circ & \text { Yes } \\ \circ & \text { No }\end{array}$

8. ONLY for those who have family in Mexico:

Where in Mexico does your family live?

9. Where do you receive your health care?

○ U.S.

○ Mexico

$\bigcirc$ Both in the U.S. and Mexico

$\circ$ Another country

10. If you are not retired now, where do you plan to retire?

$\circ$ U.S.

- Mexico

$\bigcirc$ Both in the U.S. and Mexico

$\circ$ Another country 
11. Where would you prefer to retire?

○ U.S.

○ Mexico

$\bigcirc$ Both in the U.S. and Mexico

- Another country

12. What are your reasons for choosing where to retire?

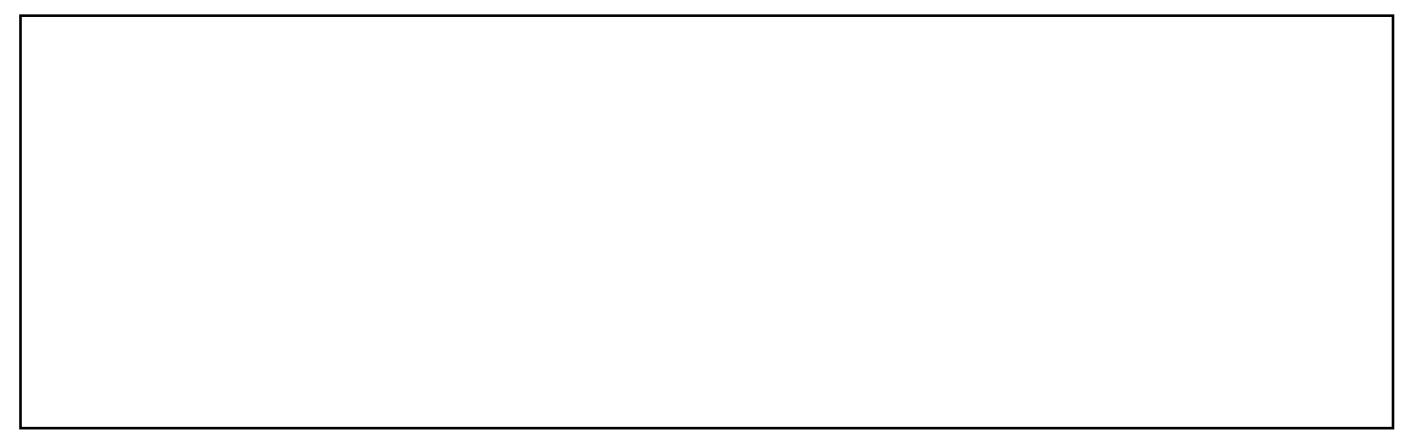

13. Of the following, what influenced or would influence your decision regarding the location of retirement? (choose all that apply)

o Closeness to family

- Living cost

- Access to Medicare benefits

$\circ$ Other (specify)

14. Are you a U.S. citizen?

○ Yes

○ No

15. Was or is your spouse a U.S. citizen?

$\begin{array}{ll}\circ & \text { Yes } \\ \circ & \text { No }\end{array}$

Other comments: 
(this page intentionally left blank) 


\section{Appendix C. Encuesta: Medicare en México}

Estimado Participante:

Gracias por participar en esta encuesta anónima. El propósito de esta encuesta es para ver si sería de beneficio que Medicare cubriera los gastos médicos para las personas mientras que vivan en México. Por favor, no escriba su nombre en cualquiera parte de la encuesta para que sea anónima.

Por favor, llene la encuesta en el web: http://www.surveymonkey.com/s/medicareespanol

Si quiere mandarla por correo, por favor mándela a la dirección:

Dr. David Warner

LBJ School of Public Affairs

Drawer Y, The University of Texas at Austin

Austin, TX, 78713

Muchas gracias por su tiempo y participación,

Equipo de Investigación

LBJ Escuela de Asuntos Públicos

La Universidad de Texas

Austin, Texas

1. Su edad (Por favor circule su respuesta):
○ 0-49
○ 50-64
○ 65 o mayor

2. Su género:
○ Hombre
○ Mujer

3. Su estado de jubilación:
○ Jubilado
○ Medio-jubilado
○ No jubilado

4. ¿Cuáles de los siguientes beneficios está recibiendo usted en este momento? (Por favor escoja todos que aplica):

\begin{tabular}{|c|c|c|c|}
\hline Medicare & Sí & No & No sé \\
\hline Medicaid & Sí & No & No sé \\
\hline
\end{tabular}




\begin{tabular}{|c|c|c|c|}
\hline Seguro Social de los Estados Unidos & Sí & No & No sé \\
\hline Seguridad de Ingreso Suplementario & Sí & No & No sé \\
\hline
\end{tabular}

5. SOLAMENTE para las personas menores de 62 años:

¿Cuáles de los siguientes beneficios recibirá usted al cumplir 65 años o mayor?

\begin{tabular}{|c|c|c|c|}
\hline Medicare & Sí & No & No sé \\
\hline Medicaid & Sí & No & No sé \\
\hline Seguro Social de los Estados Unidos & Sí & No & No sé \\
\hline Seguridad de Ingreso Suplementario & Sí & No & No sé \\
\hline
\end{tabular}

6. ¿Dónde tiene su domicilio principal? (Por favor circule solamente una respuesta)
○ Estados Unidos
- México
- Los dos países
○ Otro país

7. ¿Tiene usted familia en México?

$\begin{array}{ll}\circ & \text { Sí } \\ \circ & \text { No }\end{array}$

8. SOLAMENTE para las personas con familia en México:

¿En qué parte de México vive su familia?

9. ¿Dónde recibe su asistencia médica?
$\circ$ Estados Unidos
- México
- Los dos países
○ Otro país

10. ¿Si actualmente usted no está jubilado, en dónde se jubilará?
○ Estados Unidos
- México
- Los dos países
○ Otro país

11. ¿Dónde quisiera jubilarse?
$\circ$ Estados Unidos
- México
- Los dos países
- Otro país 
12. ¿Cuáles son sus razones para escoger el lugar en donde jubilarse?

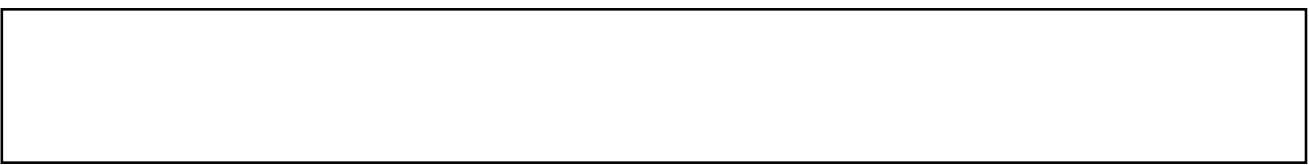

13. ¿De las siguientes opciones, cual(es) influyeron más o tendría(n) más influencia en su decisión sobre dónde jubilarse? (Por favor circule todos que aplican)

- La cercanía a la familia

- Los costos de vivir

- El acceso a los beneficios de Medicare

○ Otro (explique)

14. ¿Es usted ciudadano/a de los Estados Unidos (EEUU)?

- Sí

○ No

15. ¿Es/Era su esposo/a ciudadano/a de los Estados Unidos (EEUU)?

○ Sí

- No

Comentarios adicionales: 